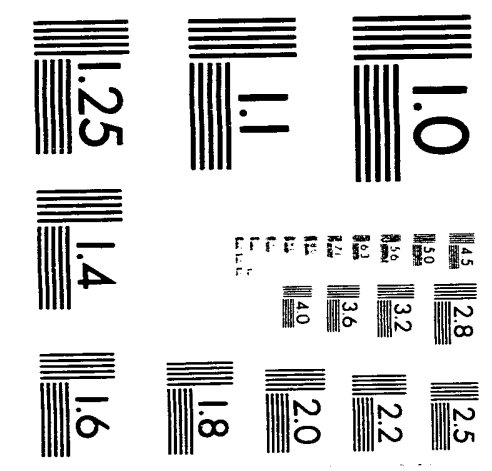



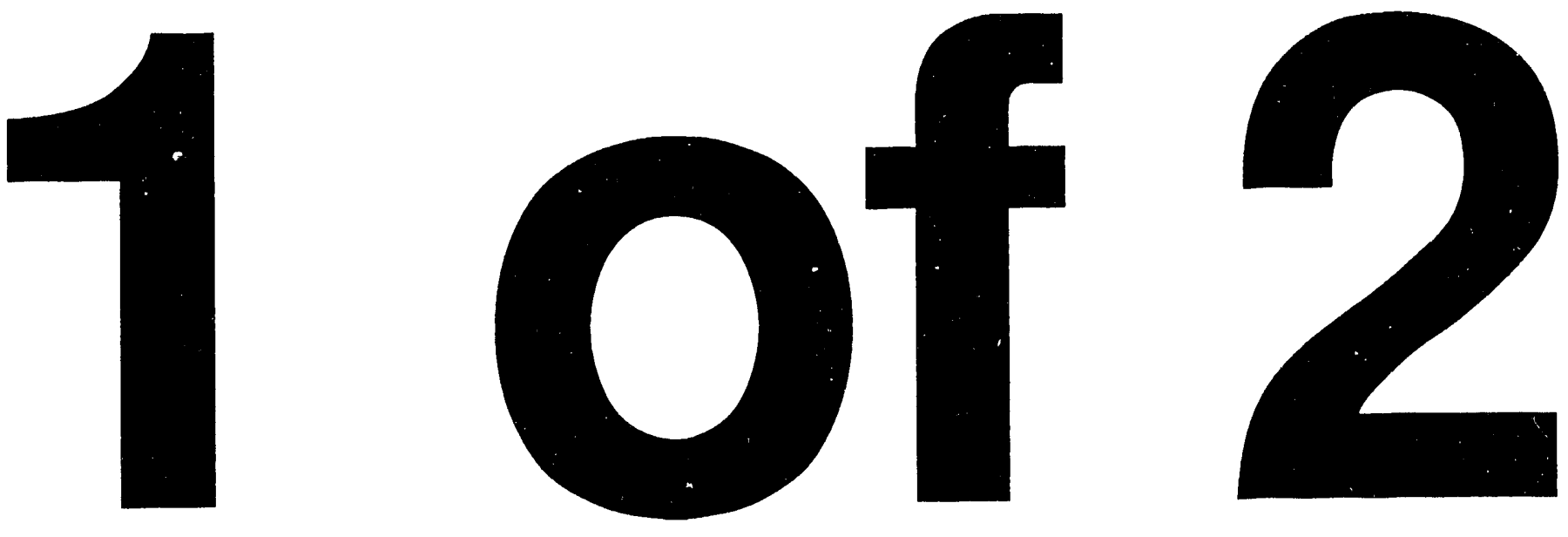
Department of Energy
Washington, DC 20545

ISEP 0$\} 1993$

\section{OUEIVED \\ OCT 181993 \\ OSTI}

Mr. Gerry A. Harvey, Director

Operations Support Services

Westinghouse Hanford Company

Post Office Box 1970

Richland, Washington 99352

Dear Mr. Harvey:

This Hazard and Operability Study (HAZOP) of the 300 Area Water Treatment Facility Chlorination System is a result of successful teamwork among the Department of Energy (DOE), Westinghouse Hanford Company (WHC), and Battelle staff members and demonstrates the use and application of a major process hazards analys is (PrHA) technique. The PrHA will support WHC chemical safety activities and provide a useful exampie for all DOE contractors.

In response to the requirements of the Process Safety Management of Highly Hazardous Chemicals (PSM) Rule (29 CFR 1910.119), DOE's Office of Safety and Quality Assurance established a PSM Program that provides guidance, training, and support to assist DOE contractors in their efforts to comply with the rule. As PrHA is considered a critical element of the rule, a demonstration analysis was planned as part of the program's 1993 work. When WHC operations personnel suggested an analys is be done of the 300 Area Water Treatment

Facility Chlorination System, it seemed ideal for the demonstration. Chlorine is the most common chemical at DOE sites that is regulated under the PSM Rule and thus a demonstration analysis of a chlorination system would have wide applicability across DOE. The HAZOP technique was selected as it was judged appropriate to the complexity of the system and would effectively identify and evaluate the system's hazards.

This study is not only an example of a PrHA that we believe complies with the PSM Rule, but also demonstrates a structured, brainstorming technique that is a practical and effective management tool for the identification and control of hazards of any process. I would like to express my appreciation for the support of the WHC personnel whose participation made this study a success.

$$
\text { Sincerely, }
$$
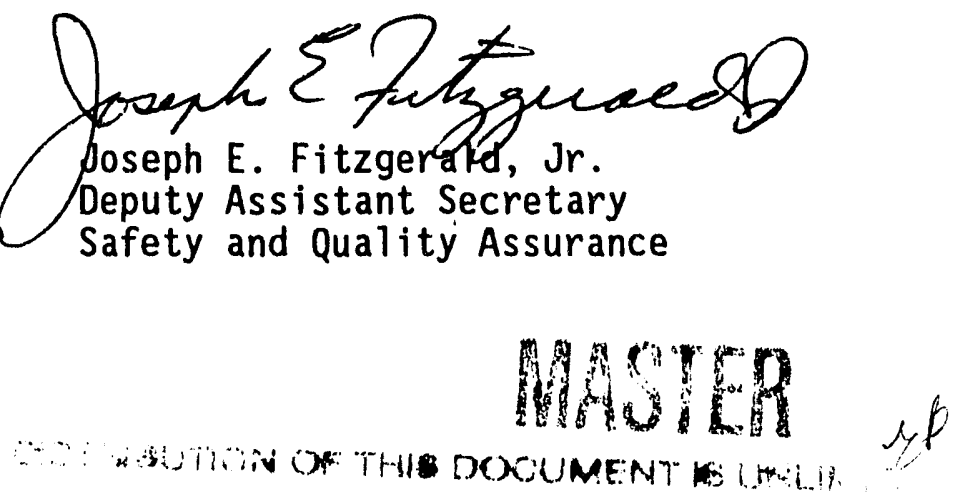


\title{
EXAMPLE PROCESS HAZARD ANALYSIS OF A DEPARTMENT OF ENERGY WATER CHLORINATION PROCESS
}

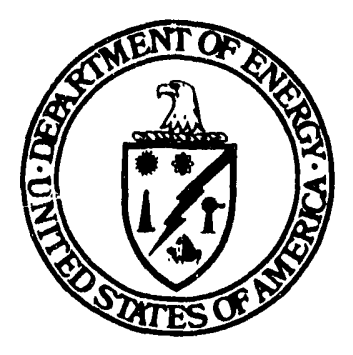

September 1993

\author{
U.S. Department of Energy \\ Assistant Secretary for Environment, Safety and Health \\ Office of Deputy Assistant Secretary for Safety and Quality Assurance \\ Washington, DC 20585
}


Comments or questions concerning this process hazard analysis or future technical assistance visits should be directed to:

Sanjeeva Kanth, EH-31

$270 \mathrm{CC}$

U.S. Department of Energy

Washington, DC 20585

301-903-4.516

Fax: 301-903-8585

Express Mail Address:

EH-31

U.S. Department of Energy

19901 Germantown Road

Germantown, MD 20874 


\section{TABLE OF CONTENTS}

Page

LIST OF TABLES $\ldots \ldots \ldots \ldots \ldots \ldots \ldots \ldots \ldots \ldots \ldots$ ii

LIST OF FIGURES $\ldots \ldots \ldots \ldots \ldots \ldots \ldots \ldots \ldots \ldots \ldots \ldots$ ii

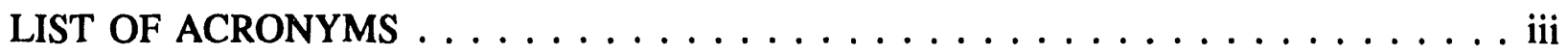

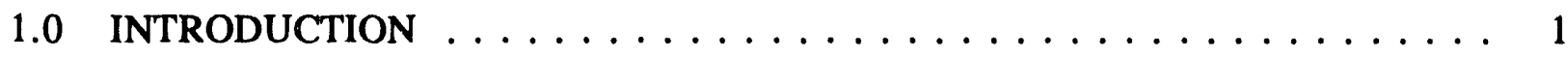

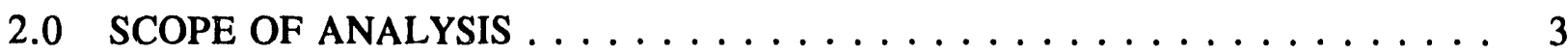

3.0 PROCESS HAZARD ANALYSIS REQUIREMENTS $\ldots \ldots \ldots \ldots \ldots$

4.0 SUMMARY OF RECOMMENDATIONS $\ldots \ldots \ldots \ldots \ldots \ldots$

5.0 PROCESS DESCRIPTION $\ldots \ldots \ldots \ldots \ldots \ldots \ldots \ldots$

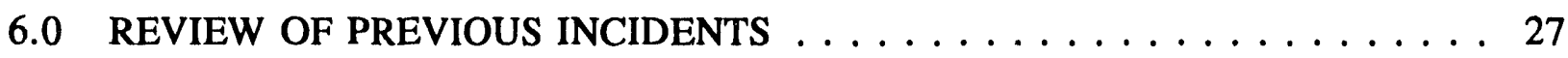

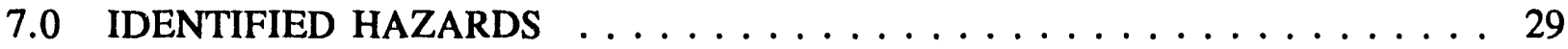

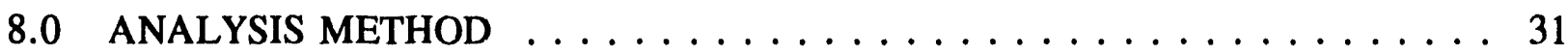

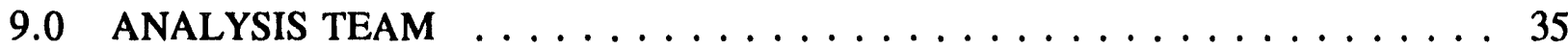

10.0 FACILITY SITING ANALYSIS $\ldots \ldots \ldots \ldots \ldots \ldots$

11.0 HUMAN FACTORS $\ldots \ldots \ldots \ldots \ldots \ldots \ldots \ldots$

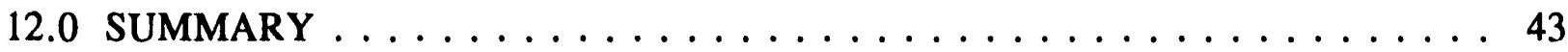

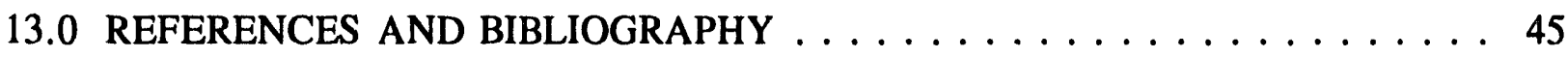

APPENDIX A: PROCEDURES FOR CHANGE-OUT OF CHLORINE CYLINDERS . A-3 APPENDIX B: HAZOP STUDY WORKSHEETS . . . . . . . . . . . . . B-3 APPENDIX C: ESTIMATING THE EFFECTS OF CHLORINE RELEASES . . . . . C-3 APPENDIX D: MATERIAL SAFETY DATA SHEET FOR CHLORINE . . . . . . D-3 APPENDIX E: RÉSUMÉS OF HAZOP STUDY TEAM . . . . . . . . . . . . . E-3 


\section{LIST OF TABLES}

Page

Table 1. HAZOP Study Action Items . . . . . . . . . . . . . . 9

Table 2. Physiological Responses and Exposure Limits for Chlorine Gas Concentrations . . . . . . . . . . . . . . . . 30

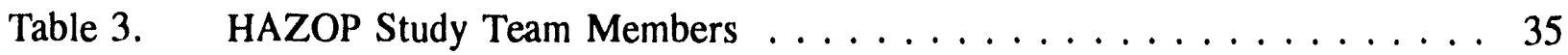

Table 4. Human Factors Checklist . . . . . . . . . . . . . . . . . . . . 40

Table C-1. Summary of Dispersion Distances and Downwind Concentrations

for Chlorine Release Scenarios . . . . . . . . . . . . . . C-7

\section{LIST OF FIGURES}

Page

Figure 1. Process Flow Diagram of the Hanford 300-Area Water Treatment Facility . 13

Figure 2. Chlorination Process Flow Diagram, Water Treatment Facility . . . . . . 15

Figure 3. Automatic Gas Feed System, Chlorination Process . . . . . . . . . . 17

Figure 4. Vacuum Regulator, Automatic Gas Feed System . . . . . . . . . . . . . 19

Figure 5. Building Housing Chlorine Cylinders and Chlorination Process Equipment . 23

Figure 6. Chlorine Cylinder Storage and Change-out Area, Overhead Door Open . . . 23

Figure 7. Chlorine Cylinders in the Chlorine Cylinder Storage Area, Front View . . . 25

Figure 8. Chlorine Cylinders in the Chlorine Cylinder Storage Area, Side View . . 25

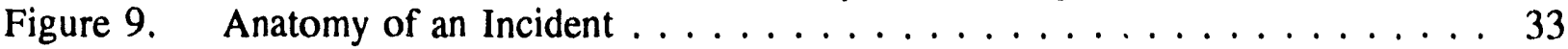

Figure B-1. Chlorination Process, Study Nodes 2 and $4 \ldots \ldots \ldots \ldots \ldots$ B-5

Figure B-2. Chlorination Process, Study Nodes 1, 3, and $4 \ldots \ldots \ldots \ldots$. . . . . .

Figure C-1. One-Ton Liquid Chlorine Release from Sheared-off Valve . . . . . . . . . C C-9

Figure C-2. Chlorine Gas Release from Sheared-off $1 / 2$-inch Tubing . . . . . . . . C-11

Figure C-3. Chlorine Gas Release from 1-inch Pipe Break . . . . . . . . . . . . C-13

Figure C-4. Liquid Chlorine Release from Sheared-off $1 / 2$-inch Tubing . . . . . . C C-15

Figure C-5. Liquid Chlorine Release from 1-inch Pipe Break . . . . . . . . . C C-17 


\title{
LIST OF ACRONYMS
}

\author{
AIChE American Institute of Chemical Engineers \\ BLEVE boiling liquid expanding vapor explosion \\ CFR Code of Federal Regulations \\ DOE U.S. Department of Energy \\ HHC highly hazardous chemical \\ HAZMAT hazardous materials \\ HAZOP hazard and operability \\ IDLH immediately dangerous to life or health \\ MSDS Material Safety Data Sheet \\ ORPS Occurrence Reporting and Processing System \\ OSHA Occupational Safety and Health Administration \\ PrHA process hazard analysis \\ PNL Pacific Northwest Laboratory \\ ppm part per million \\ PSM process safety management \\ SCBA self-contained breathing apparatus \\ TQ threshold quantity \\ WAC Washington State Administrative Code \\ WHC Westinghouse Hanford Company
}




\section{EXAMPLE PROCESS HAZARD ANALYSIS \\ OF A DEPARTMENT OF ENERGY \\ WATER CHLORINATION PROCESS}

\subsection{INTRODUCTION}

On February 24, 1992, the Occupational Safety and Health Administration (OSHA) released a revised version of Section 29 Code of Federal Regulations (CFR) Part 1910 that added Section 1910.119, entitled "Process Safety Management of Highly Hazardous Chemicals" (the PSM Rule). Because U.S. Department of Energy (DOE) Orders 5480.4 and 5483.1A prescribe OSHA 29 CFR 1910 as a standard in DOE, the PSM Rule is mandatory in the DOE complex.

A major element in the PSM Rule is the process hazard analysis (PrHA), which is required for all chemical processes covered by the PSM Rule. The PrHA element of the PSM Rule requires the selection and application of appropriate hazard analysis methods to systematically identify hazards and potential accident scenarios associated with processes involving highly hazardous chemicals (HHCs).

The analysis in this report is an example PrHA performed to meet the requirements of the PSM Rule. The PrHA method used in this example is the hazard and operability (HAZOP) study, and the process studied is the new Hanford 300-Area Water Treatment Facility chlorination process, which is currently in the design stage. The HAZOP study was conducted on May 18-21, 1993, by a team from the Westinghouse Hanford Company (WHC), Battelle-Columbus, the DOE, and Pacific Northwest Laboratory (PNL). The chlorination process was chosen as the example process because it is common to many DOE sites, and because quantities of chlorine at those sites generally exceed the OSHA threshold quantities (TQs).

The report is organized into 13 sections and 5 appendices. Section 2.0 summarizes the requirements of the PSM Rule for performing PrHAs. Section 3.0 describes the scope and assumptions used in the analysis. Section 4.0 presents a list of recommendations and action items developed during the HAZOP study. Section 5.0 is an overview of the Hanford 300-Area Water Treatment Facility chlorination process, including process diagrams.

Section 6.0 contains brief descriptions of previous incidents at the Hanford 300-Area Water Treatment Facility involving the old chlorination process, and Section 7.0 summarizes the hazards of chlorine. Section 8.0 describes the HAZOP study method, and Section 9.0 lists the HAZOP team members and their roles.

Section 10.0 describes the location of the Hanford 300-Area Water Treatment Facility in relation to the public and to employees. Section 11.0 presents a brief discussion of the possible causes of human errors identified during the HAZOP study. The HAZOP summary is presented in Section 12.0, and Section 13.0 contains the study references. 
Appendix A of this report contains the procedure for change-out of chlorine cylinders. The HAZOP study worksheets are provided in Appendix B. The effects of chlorine releases are estimated in Appendix C. Appendix D contains a Material Safety Data Sheet for chlorine. Appendix E presents the resumes of the HAZOP study team members. 


\subsection{SCOPE OF ANALYSIS}

This report illustrates the use of the process hazard analysis (PrHA) required by the Occupational Safety and Health Administration (OSHA) rule 29 CFR 1910.119, "Process Safety Management of Highly Hazardous Chemicals" (the PSM Rule). The Hanford 300-Area Water Treatment Facility chlorination process was selected for analysis because it is a process common to many U.S. Department of Energy (DOE) sites, and quantities of chlorine at those sites generally exceed the OSHA threshold quantities (TQs). The analysis method selected was the hazard and operability (HAZOP) study.

The HAZOP study was performed on the new chlorination process design at the Hanford 300-Area Water Treatment Facility. At the time of the study, the new system was partially installed but not operating. The HAZOP study consisted of four full-day sessions and covered both the chlorination process and the procedures for change-out of chlorine cylinders. The worksheets in Appendix B document the HAZOP study.

The study assumed that the chlorination process was essential and that questions regarding elimination or replacement of chlorine with other types of disinfection technologies were outside of scope. Although a separate seismic analysis was not performed, seismic failures were considered similar to existing HAZOP study scenarios (e.g., line, valve, and cylinder failures).

Additional information regarding the PSM Rule and the performance of PrHAs is available in the DOE Guideline: Preliminary Guide for Conformance with OSHA's Rule for Process Safety Management of Highly Hazardous' Chemicals (Draft, DOE/EH, March 1993), and the DOE Guideline: Guide for Chemical Process Hazard Analysis (Draft, DOE/EH, March 1993). 


\subsection{PROCESS HAZARD ANALYSIS REQUIREMENTS}

This section provides a general overview of the process safety management (PSM) requirements and objectives for conducting process hazard analyses (PrHAs) under the Occupational Safety and Health Administration (OSHA) rule 29 CFR 1910.119, the PSM Rule. This section would not normally be included in a PrHA. Rather, in its place would be a section discussing the specific objectives that management wished to accomplish in the PrHA.

\section{$3.1 \quad$ Objectives}

The objective of the PSM rule is to protect employees by preventing or minimizing the consequences and impacts o. chemical accidents involving highly hazardous chemicals (HHCs). This objective is partly fulfilled by performance of PrHAs to identify hazards and recommend safety improvements in the design and operation of chemical processes. The scope and level of detail of a PrHA must be appropriate to the complexity of the chemical process being evaluated. A PrHA should

- Identify the hazards of a process

- Evaluate previous process incidents that had the potential to cause catastrophic consequences or impacts in the workplace

- Evaluate the engineering and/or administrative controls applicable to the process hazards and their interrelationships (e.g., detection methods for releases)

- Identify the consequences of failure of engineering and/or administrative controls

- $\quad$ Review facility siting issues

- Evaluate the importance of human factors on the likelihood and/or consequences of process accidents

- Evaluate qualitatively the range of possible safety and health effects on employees from failure of engineering and/or administrative controls

- Identify procedural or process safety improvements to better control process hazards. 


\subsection{Review Team}

The PSM Rule requires that a PrHA be conducted by a team consisting of the following individuals:

- At least one member with expertise in engineering and process operations

- At least one member with experience and knowledge specific to the process being evaluated

- A team leader knowledgeable in the specific PrHA methodology being used.

\subsection{Schedule}

If facilities have more than one process covered by the PSM Rule, facility management must determine and document the priority order for conducting PrHAs for all the covered processes. The order for completing PrHAs should be based on a rationale that includes such considerations as

- The extent of the process hazard

- The number of potentially affected employees

- The age of the process

- The operating history of the process.

PrHAs for processes covered by the PSM Rule must be completed according to the following schedule:

- $\quad$ No less than 25 percent by May 26, 1994

- $\quad$ No less than 50 percent by May 26, 1995

- $\quad$ No less than 75 percent by May 26, 1996

- $\quad$ All of the initial PrHAs (100 percent) by May 26, 1997.

PrHAs completed after May 26, 1987, that meet the requirements of the PSM Rule are acceptable as initial PrHAs. They must be updated and revalidated in accordance with the PSM Rule requirements.

\subsection{Methodology}

The PrHA element of the PSM Rule requires the selection and application of appropriate hazard analysis methods to systematically identify hazards and related accident scenarios associated with highly hazardous chemicals. Although the PSM Rule allows the use of several different methods, it requires that the selection of a particular method be based on consideration of the process being analyzed. One or more of the following methods, or 
an appropriate equivalent method, must be used: what-if study, checklist, what-if/checklist, HAZOP study, failure mode and effects analysis, and/or fault tree analysis.

\subsection{Recommendations and Updates}

The resolution of PrHA findings and recommendations are not part of a PrHA, per se. However, an employer must establish a system to promptly address a PrHA team's findings and recommendations. A schedule for resolutions must be established to assure that all recommendations are resolved and documented. All actions taken as a result of PrHA findings must be completed as soon as possible and must be reported to employees involved in the process and to any other individuals affected by the recommendations or actions.

Every 5 years the PrHA must be updated to ensure it is consistent with the current process, configuration, and operation. The PrHA, related updates, and the documented resolution of the recommendations are required to be maintained for the life of the process. 


\section{4.0 SUMMARY OF RECOMMENDATIONS}

The action items and recommendations developed by the process hazard analysis (P (PrHA) team during the hazard and operability (HAZOP) study are presented in Table 1. Th The HAZOP study worksheets from which these action items and recommendations were de derived are included in Appendix B.

Action items are typically assigned to specific individuals who are named in the " $R$ "Responsibility" column in the matrix. However, because this report is an example PrHA, thi this column is left blank.

Table 1. HAZOP Study Action Items

\begin{tabular}{|c|c|c|c|}
\hline $\begin{array}{l}\text { ACTION } \\
\text { ITEM }\end{array}$ & SCENARIO & ACTION & RESPONSIBILITY \\
\hline 1 & $1-4$ & $\begin{array}{l}\text { Check on the possibility of backflow past the } \\
\text { rate indicator (rotameter) and adjust the } \\
\text { procedures as needed. }\end{array}$ & \\
\hline 2 & $1 \cdot 9,3-1$ & $\begin{array}{l}\text { Consider adding a procedure to verify that the } \\
\text { vacuum can be maintained after the system is } \\
\text { shut down to test for system leak tightness. } \\
\text { This procedure should be used when the } \\
\text { chlorinators are switched each month and } \\
\text { whenever the polyethylene chlorine gas feed } \\
\text { tubing is replaced. }\end{array}$ & \\
\hline 3 & $1-13$ & $\begin{array}{l}\text { Verify that staff in adjacent buildings have } \\
\text { received information on chlorine in their } \\
\text { hazard communication (HAZCOM) program. }\end{array}$ & \\
\hline 4 & $2-5$ & $\begin{array}{l}\text { Calculate possible temperatures (based on heat } \\
\text { input versus heat loss) inside the chlorine } \\
\text { cylinder storage facility if the heater } \\
\text { thermostat fails "on" during peak outside } \\
\text { temperatures. Base further action items on the } \\
\text { results. Other key equipment affected by } \\
\text { excessive temperatures should be considered. } \\
\text { See the high-temperature alarm failure incident } \\
\text { in Section } 6.0 \text {. }\end{array}$ & \\
\hline 5 & $2-8$ & $\begin{array}{l}\text { Check pressure potential from the chlorine } \\
\text { cylinder and the system (regulator) response. } \\
\text { Determine whether the fusible plug will open } \\
\text { with high pressure. }\end{array}$ & \\
\hline
\end{tabular}


Table 1. HAZOP Study Action Items (Continued)

\begin{tabular}{|c|c|c|c|}
\hline $\begin{array}{l}\text { ACTION } \\
\text { ITEM }\end{array}$ & SCENARIO & ACTION & RESPONSIBILITY \\
\hline 6 & $2-10,2-11$ & $\begin{array}{l}\text { Check with the vendor regarding possible } \\
\text { entry of material other than chlorine into the } \\
\text { chlorine cylinder or the possibility of complete } \\
\text { substitution of another chemical that uses the } \\
\text { same size container. }\end{array}$ & \\
\hline 7 & $3-2$ & $\begin{array}{l}\text { Contact the vendor to determine the failure } \\
\text { experience of the regulator failing "open" } \\
\text { from wear, corrosion, dirt, or water. If the } \\
\text { regulator has a relatively high probability of } \\
\text { failing, controls (e.g., a remotely operated } \\
\text { shutoff at the chlorine cylinder and failsafe } \\
\text { action upon power loss) should be considered. }\end{array}$ & \\
\hline 8 & $3-10$ & $\begin{array}{l}\text { Verify that the screens are in place on the } \\
\text { regulator vents. }\end{array}$ & \\
\hline 9 & $4-4$ & $\begin{array}{l}\text { The explanation of how the differential } \\
\text { pressure regulator operates is missing from the } \\
\text { vendor's documentation. This information } \\
\text { should be ohtained. The operation of the } \\
\text { valve should be checked, and the potential for } \\
\text { a pressure deviation should be assessed. }\end{array}$ & \\
\hline 10 & $4-13$ & $\begin{array}{l}\text { Verify that monthly preventative maintenance } \\
\text { includes checking the battery backup for the } \\
\text { chlorine alarm. }\end{array}$ & \\
\hline 11 & $5-24$ & $\begin{array}{l}\text { Ensure that the intent to incorporate the } \\
\text { existing identification tagging into the } \\
\text { disconnect procedures is completed. }\end{array}$ & \\
\hline 12 & $0-16$ & $\begin{array}{l}\text { Consult the vendor about what the expected } \\
\text { system response would be if the serviceman } \\
\text { did not properly vertically align the chlorine } \\
\text { tank (drawing liquid to the ejector). Determine } \\
\text { the potential amount of chlorine that could be } \\
\text { released. }\end{array}$ & \\
\hline
\end{tabular}




\subsection{PROCESS DESCRIPTION}

The Hanford 300-Area Water Treatment Facility uses gaseous chlorine to disinfect the drinking water supply at the Hanford Site 300-Area in accordance with the Washington State Administrative Codes (WAC) 246-290. Two independent chlorination systems are installed at the Water Treatment Facility. These systems can be operated separately or in parallel. Because they are typically operated separately, this study addresses only one system. Figures 1 through 4 are simplified diagrams of the chlorination process. Figures 5 through 8 are photographs of the chlorine cylinder storage area and the chlorination room. The chlorination system was partially installed and not yet operating at the time of the hazard and operability (HAZOP) study.

Within the chlorine cylinder storage area of the Water Treatment Facility, liquid chlorine is stored in two 1-ton cylinders (see Figures 6, 7, and 8). One cylinder is normally in service, and the other is in standby mode for use when the contents of the in-service cylinder are depleted.

Chlorine leak detection and warning are provided by two sets of alarms. The alarms sound locally at the Water Treatment Facility and remotely at a separate facility that is staffed 24 hours a day. One alarm indicates a chlorine concentration of 1.0 part per million (ppm) and is used to detect a slow buildup of chlorine. A second alarm, set at $5.0 \mathrm{ppm}$, is used to detect larger chlorine releases. The chlorine cylinder storage area is also equipped with a manually activated exhaust vent system to evacuate chlorine before personnel entry.

Chlorine cylinders are placed on trunnions and dollies to move them in and out of the storage area (see Figure 6). The dollies operate on fixed tracks with "stops" to prevent them from traveling too far. Wheel chocks prevent movement of the dollies while the chlorine cylinders are in use.

Two gaseous chlorinators are installed in a separate room adjacent to the chlorine cylinder storage area. The chlorinators meter and inject gaseous chlorine into the raw water supply as it enters the Water Treatment Facility sedimentation basins. The chlorination room is equipped with an exhaust vent fan and chlorine leak detection system. The leak detector is equipped with alarm capabilities that alarm both locally and remotely at a separate facility that is staffed 24 hours a day.

Chlorine gas is supplied from the in-service chlorine cylinder at approximately 75 psig to a vacuum regulator mounted directly to the cylinder gas supply valve. An automated switch-over valve is installed between the containers to allow both containers to be connected to the in-use chlorinator at the same time. As one container approaches depletion, a sensor detects the high-vacuum condition causing the valve to switch to the standby container. The vacuum regulator reduces the pressure from the cylinder by using a water ejector to create a vacuum within the system. The regulator is designed to fail "closed" any time a loss of vacuum is experienced within any component of the system. The regulator is also designed to relieve the pressure from the system. 
Gaseous chlorine is drawn through a flow rate indicator/controller, an automatic control valve, and a differential pressure regulator, to a water ejector. The chlorine rate indicator is set manually to maintain a feed rate of 20 to 60 pourids per day. Feed rate depends on ambient weather conditions and the quantity of water processed. Chlorine gas is mixed with water from the clear-well as the gas passes into the water stream at the water ejector. The chlorinated water is then discharged into the raw water supply at the influent chamber, where initial treatment of the water supply begins. The water undergoes sedimentation and filtering (rapid sand filters) before entering the 70,000-gallon clear-well reservoir.

The water system is monitored during each shift for residual chlorine. Monitoring occurs at the clear-well and at various facilities throughout the Hanford 300-Area to assure that the proper ar ount of chlorine is present to effectively disinfect the water supply. Depending on th: results of the monitoring, the chlorine feed rate is manually adjusted to maintair.

Chlorine cylinders are delivered to the chlorine cylinder storage building on flat bed trucks as needed. The cylinders are loaded and unloaded from the truck using a mobile crane. Hoisting and rigging crews are trained to perform the loading and unloading activities.

In case of system outages, a water line from the City of Richland can temporarily supply water to the Hanford 300-Area. 


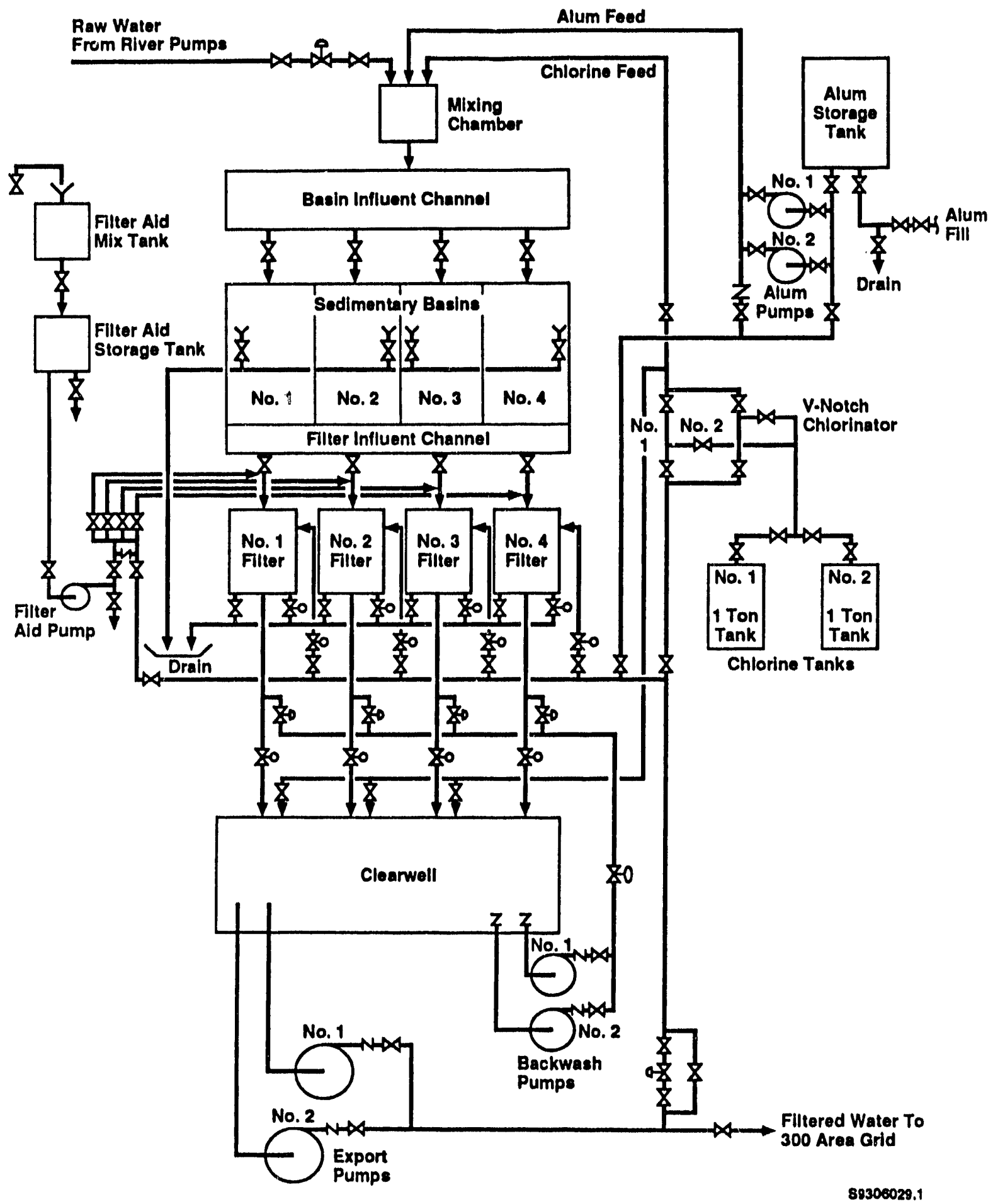

Figure 1. Process Flow Diagram of the Hanford 300-Area Water Treatment Facility 


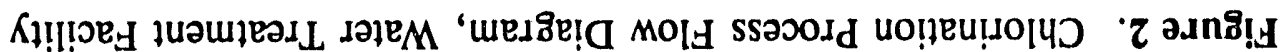

$\forall / \cdot 20090 \varepsilon 6 \varepsilon$

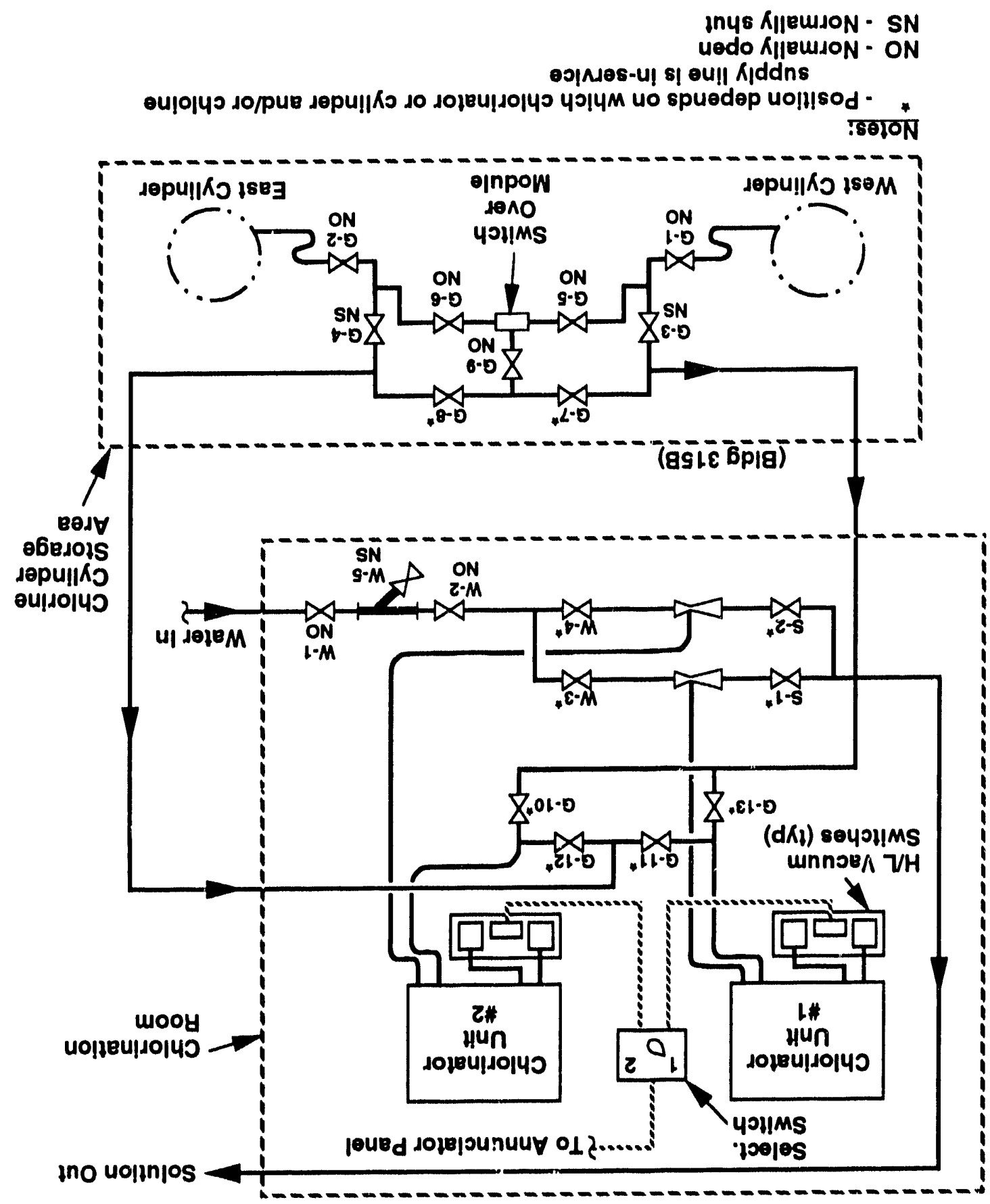




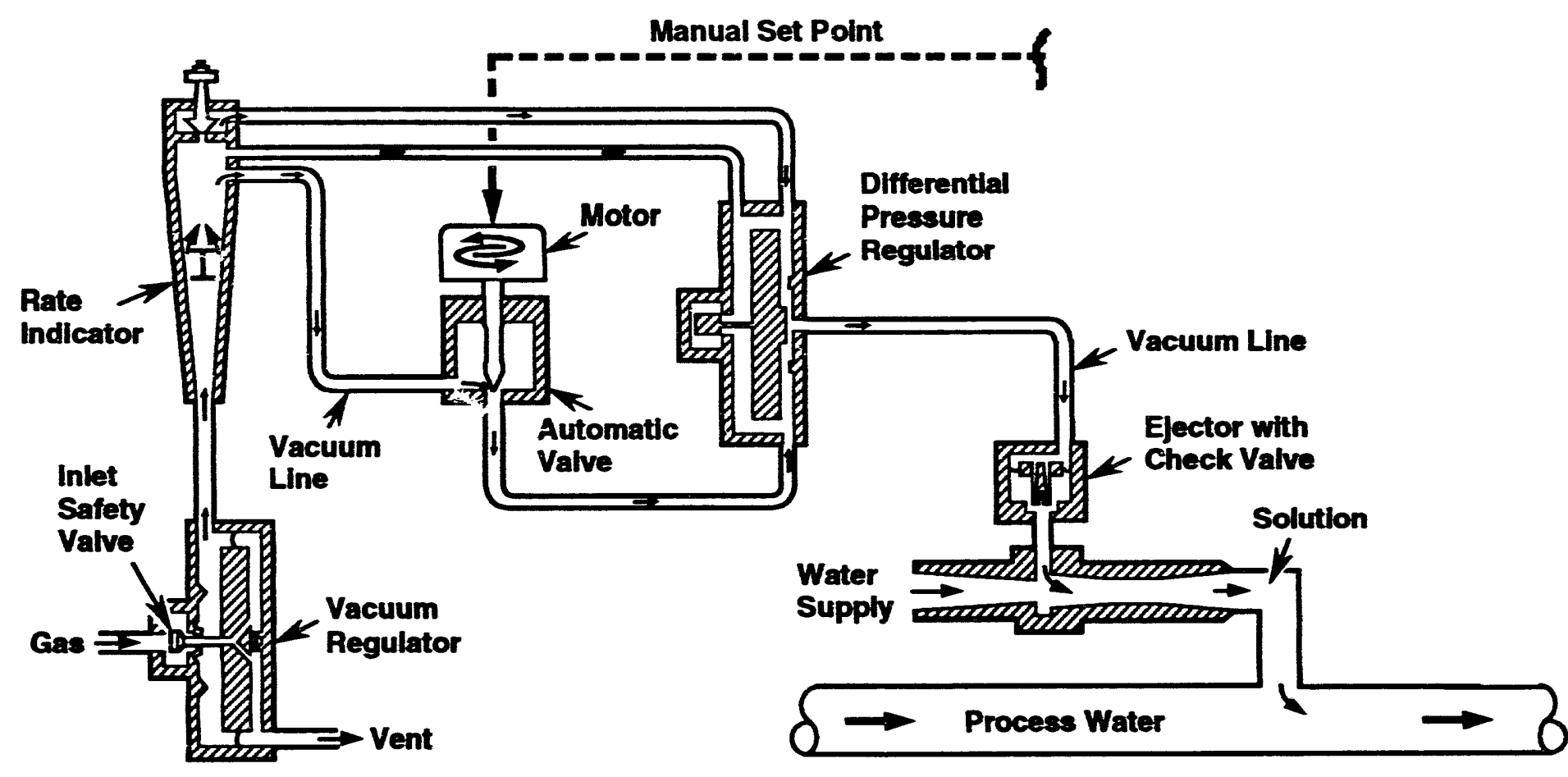




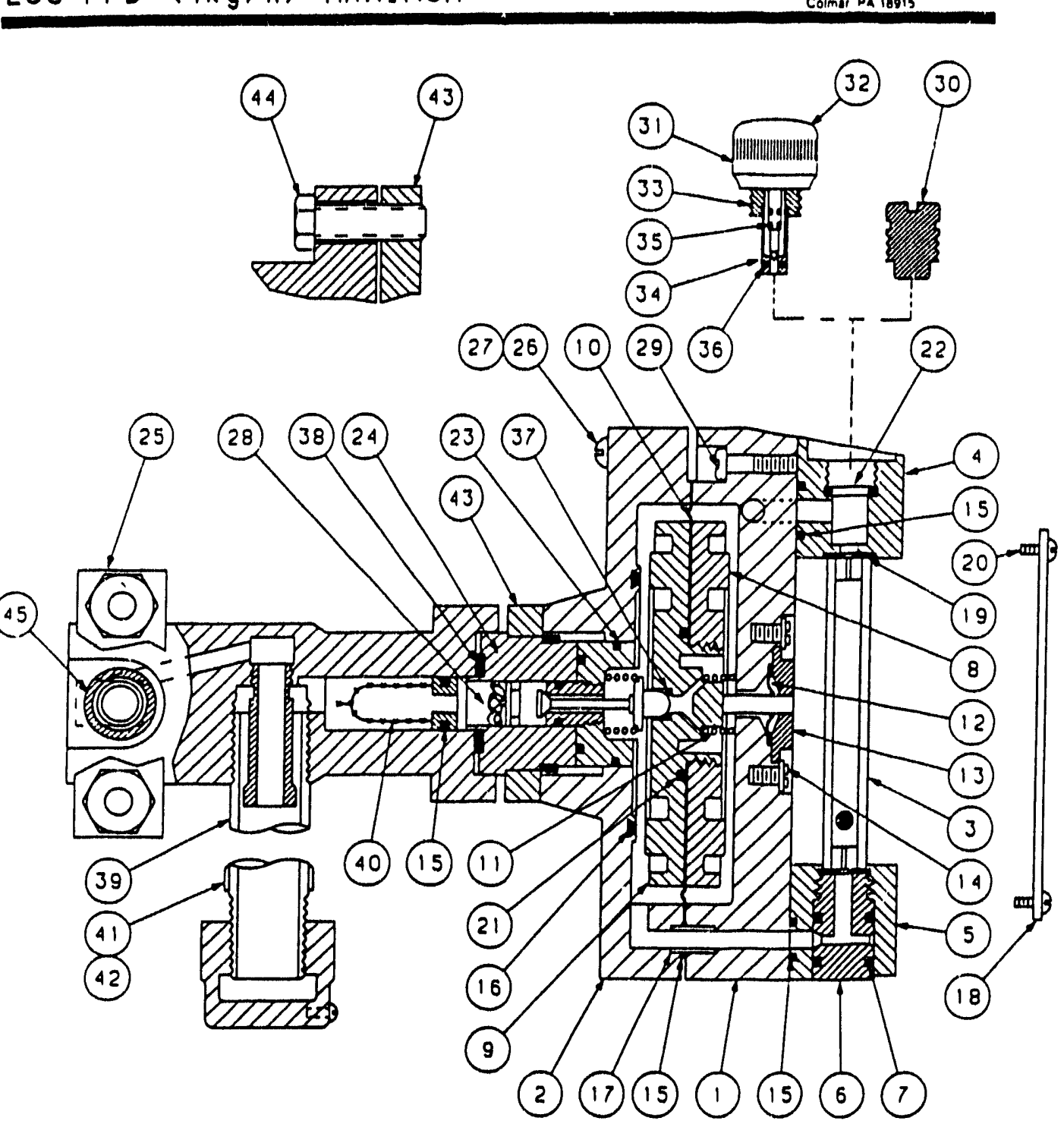

COPYRIOHT 1992 CAPITAL CONTROLS

Figure 4. Vacuum Regulator, Automatic Gas Feed System 


\begin{tabular}{|c|c|c|c|c|c|c|c|}
\hline ITEMNO, & gry. & DESCRIPTION & PARTNO & ITEMNO & QTY. & DESCAIPTION & PART NO \\
\hline $\begin{array}{r}1 \\
2 \\
3 \\
4 \\
5 \\
\end{array}$ & $\begin{array}{l}1 \\
1 \\
1 \\
1 \\
1\end{array}$ & $\begin{array}{l}\text { FRONT BODY } \\
\text { BACK BODY } \\
\text { FLOWMETER ASSEMBLY } \\
\text { FLOWMETEA TOP FITTINO } \\
\text { FLOWMETER BOTTOM FITTINO }\end{array}$ & $\begin{array}{l}\text { SEE CHART IV } \\
\text { U.100 } \\
\text { SEE CHART I } \\
\text { M.117 } \\
\text { M.118 } \\
\end{array}$ & $\begin{array}{r}20 \\
27 \\
+28 \\
20 \\
30 \\
\end{array}$ & $\begin{array}{l}2 \\
6 \\
1 \\
4 \\
1\end{array}$ & $\begin{array}{l}\text { SCREW, } 1 / 4.20 \times 2.3 / 4 \text { LO } \\
\text { SCREW, } 1 / 4.20 \times 1.3 / 4 \text { LO } \\
\text { AEPLACEMENT FILTER (SEE NOTE O) } \\
\text { SCREW, } 10.24 \times 1 \text { LO } \\
\text { BONNET PLUO }\end{array}$ & $\begin{array}{l}N \cdot 126 \\
N \cdot 124 \\
B M \cdot 1023 \\
N \cdot 126 \\
M \cdot 17 B \\
\end{array}$ \\
\hline $\begin{array}{r}+6 \\
+7 \\
+\quad 8 \\
+\quad 9 \\
+\quad 10 \\
\end{array}$ & $\begin{array}{c}1 \\
2 \\
1 \\
1 \\
1 \\
\text { s skT }\end{array}$ & $\begin{array}{l}\text { METER INLET PLUG } \\
\text { O-RING } \\
\text { DIAPHAAGM FRONT PLATE } \\
\text { DIAPHAABM BACK PLATE } \\
\text { DIAPHRABM 12 PEA SETI } \\
\end{array}$ & $\begin{array}{l}U \cdot 140 \\
\text { OV. } 11.112 \\
U .208 \\
\text { A.3.3 } \\
0.100 \\
\end{array}$ & $\begin{array}{r}31 \\
32 \\
33 \\
34 \\
+\quad 36 \\
\end{array}$ & $\begin{array}{l}1 \\
1 \\
1 \\
2\end{array}$ & $\begin{array}{l}\text { RATE VALVE ASSEMBLY } \\
\text { VALVE STEM ASSEMBLY } \\
\text { VALVE BONNET } \\
\text { VALVE SLEEVE } \\
\text { O-RINO } \\
\end{array}$ & $\begin{array}{l}\text { SEE NOTE 3 } \\
\text { SEE CHART I } \\
\text { V.124 } \\
\text { SEE CHART I } \\
\text { OV. } 11.008 \\
\end{array}$ \\
\hline $\begin{array}{r}11 \\
+12 \\
13 \\
14 \\
+16 \\
\end{array}$ & $\begin{array}{l}1 \\
1 \\
1 \\
2 \\
4\end{array}$ & $\begin{array}{l}\text { RELIEF SPRINO } \\
\text { SEALINO DIAPHAAOM } \\
\text { SEAL COVER } \\
\text { SCAEW, } 10.24 \times 3 / 10 \text { LO } \\
\text { O.RINO } \\
\end{array}$ & $\begin{array}{l}8 \cdot 100 \\
D \cdot 102 \\
U \cdot 137 \cdot 1 \\
N \cdot 128 \\
\text { OV.11-012 }\end{array}$ & $\begin{array}{r}38 \\
+\quad 37 \\
+\quad 38 \\
30 \\
+\quad 40 \\
\end{array}$ & $\begin{array}{l}1 \\
1 \\
1 \\
1 \\
\end{array}$ & $\begin{array}{l}\text { O.RINO } \\
\text { O.RING } \\
\text { LEAD OASKET (SEE NOTE B) } \\
\text { INLET ASSEMBLY } \\
\text { INLET FILTEA ASSEMBLY }\end{array}$ & $\begin{array}{l}\text { OV.11.010 } \\
\text { OV.11.008 } \\
\text { O.111 } \\
\text { SEE CHART III } \\
\text { BM-1270 } \\
\end{array}$ \\
\hline $\begin{array}{r}+16 \\
+17 \\
18 \\
118 \\
20 \\
\end{array}$ & $\begin{array}{l}1 \\
1 \\
1 \\
2 \\
2\end{array}$ & $\begin{array}{l}\text { O.AINO } \\
\text { FLOW TUEE } \\
\text { FAONT PLATE } \\
\text { METER OASKET } \\
\text { SCAEW, } 0.32 \times 1 / 410 \\
\end{array}$ & $\begin{array}{l}\text { OV.11.332 } \\
\text { U.162 } \\
\text { A.2204 } \\
\text { SEE CHART I } \\
\text { N.302 } \\
\end{array}$ & $\begin{array}{r}141 \\
+42 \\
43 \\
44 \\
46 \\
\end{array}$ & $\begin{array}{l}1 \\
2 \\
1 \\
2 \\
1 \\
\end{array}$ & $\begin{array}{l}\text { HEATEA } \\
\text { MOUNTINO CLIP } \\
\text { BODY PLATE } \\
\text { BOLT, HEX } 3 / 8-10 \times 1 \text { LO } \\
\text { LEAD OASKET (BEE NOTE BL }\end{array}$ & $\begin{array}{l}\text { SEE CHART II } \\
\text { T.468 } \\
T .1183 .1 \\
N \cdot 139 \\
\text { SEE CHART III }\end{array}$ \\
\hline $\begin{array}{r}+21 \\
+22 \\
+\quad 23 \\
+24 \\
26\end{array}$ & $\begin{array}{l}1 \\
1 \\
1 \\
1\end{array}$ & $\begin{array}{l}\text { O.RINO } \\
\text { O-AINO } \\
\text { O-RINO ISEE NOTE GI } \\
\text { INLET CAPSULE ASSEMBLY } \\
\text { YOKE ASSEMBLY (SEE NOTE A) }\end{array}$ & $\begin{array}{l}\text { OV. } 11.028 \\
\text { OV. } 11.110 \\
\text { OV. } 11.212 \\
\text { BM-48.89 } \\
\text { SEE CHART III }\end{array}$ & $\begin{array}{l}+N / S \\
+N / 8 \\
N / S=N O I\end{array}$ & $\begin{array}{c}1 \\
1 \\
\text { OWN }\end{array}$ & $\begin{array}{l}\text { 3/8 TUBINO CONNECTOA (VENT) } \\
1 / 2 \text { TUBINO CONNECTOA (VACUUM) }\end{array}$ & $\begin{array}{l}F .100 \\
F \cdot 100\end{array}$ \\
\hline
\end{tabular}

CHART I

\begin{tabular}{|c|c|c|c|c|}
\hline \multirow{2}{*}{$\begin{array}{l}\text { ITEM } \\
\text { NO. }\end{array}$} & \multicolumn{4}{|c|}{ CAPACITY IN PPD IKOMI } \\
\hline & $\begin{array}{c}26 \\
10.61 \\
\end{array}$ & $\begin{array}{c}50 \\
(1.0)\end{array}$ & $\begin{array}{r}100 \\
12.01 \\
\end{array}$ & $\begin{array}{r}200 \\
14.01 \\
\end{array}$ \\
\hline 3 & A 108.8 & A.108.6 & A.108.8 & A.108.8 \\
\hline 10 & $0.100 \cdot 6$ & 0.100 .7 & 0.100 .7 & 0.100 .4 \\
\hline 31 & $B M-118.3$ & $B M \cdot 118.3$ & $B M \cdot 118.3$ & $B M \cdot 118-4$ \\
\hline 32 & A.050.3 & A.660.3 & A.658.3 & A.658.4 \\
\hline 34 & V.126-3 & V.125.3 & V.126.3 & $V \cdot 126.4$ \\
\hline
\end{tabular}

\begin{tabular}{c|c|c|}
\multicolumn{2}{c|}{ CHART II } \\
\hline ITEM & \multicolumn{2}{|c|}{ VOLTAOE } \\
NO. & 120 VAC & 240 VAC \\
\hline 41 & 28 WATT & 28 WATT \\
\hline R.111 & R.200 \\
\hline
\end{tabular}

\begin{tabular}{|c|c|c|c|}
\hline \multicolumn{4}{|c|}{ CHART III } \\
\hline \multirow{2}{*}{$\begin{array}{c}\text { ITEM } \\
\text { NO, }\end{array}$} & \multicolumn{3}{|c|}{ CONNECTIONS } \\
\hline & $\begin{array}{c}\text { U.8. } \\
\text { LEFT HAND }\end{array}$ & $\begin{array}{c}\text { U.S. } \\
\text { RIOHT HAND }\end{array}$ & JAPAN \\
\hline 25 & $A 128$ & $A-128$ & A.826 \\
\hline 30 & A.738.L & A738.R & BM.1180 \\
\hline 48 & 0.111 & 0.111 & 0.120 \\
\hline
\end{tabular}

CHART IV
\begin{tabular}{c|c|c|}
\hline ITEM & $\begin{array}{c}\text { WTH LOSS OF } \\
\text { OAS SWTCH }\end{array}$ & $\begin{array}{c}\text { WTHOUT LOSS } \\
\text { OF OAS SWTCH }\end{array}$ \\
\hline 1 & SEE PM B3.7133 & A.107 \\
\hline
\end{tabular}

\footnotetext{
NOTES:

1. $\quad 1+1$ AND $(\circ)$ INDICATES RECOMMENDED AS MINIMUM SPARE PARTS. QUANTITY RECOMMENDATIONB ARE FOR AVERAQE USE AND CONDITIONB. ADDITIONAL. PAATS AND OUANTITIES SHOULD BE CONSIDEAED WHEAE THE EQUIPMENT IS USEO TO ITS FULLEST CAPABILITY OR WHERE LOCATED IN AN AREA REMOTE FROM CONVENIENT SERVICE.

(A) TO ORDER RECOMMENDED SPARE PARTS INDICATED BY $1+1$ SPECIFY BM-3250.

(B) TO ORDER RECOMMENDED SPAAE PARTS INDICATED BY $1 \%$ SPECIFY INDIVDUAL PARTS

2. WHEN ORDEAINC PARTS, SPECIFY OAS FEEDEA CAPACITY, MODEL NIIMBEA, AND SERINL NUMBER.

3. ITEM NO, 31 INCLUDES ITEM NOS, 22, 32, 33, 34, 38, AND 36. TO ORDER COMPLETE RATE VALVE ASSEMBLY SEE CHART I.

4. ITEM 25 YOKE ASSEMBLY IS INCLUDED IN ITEM 39 INLET ASSEMBLY.

b. TO ORDEA TWELVE (12) BASKETS SPECIFY THE FOLLOWNO: FOR 0.111 SPECIFY BM.018 FOR 0.120 SPECIFY BM. 018

6. ITEM 23 O.AINO AND ITEM 28 FILTER INCLUDED IN ITEM 24 INLET ASSEMBLY.
}

Figure 4. Vacuum Regulator, Automatic Gas Feed System (continued) 


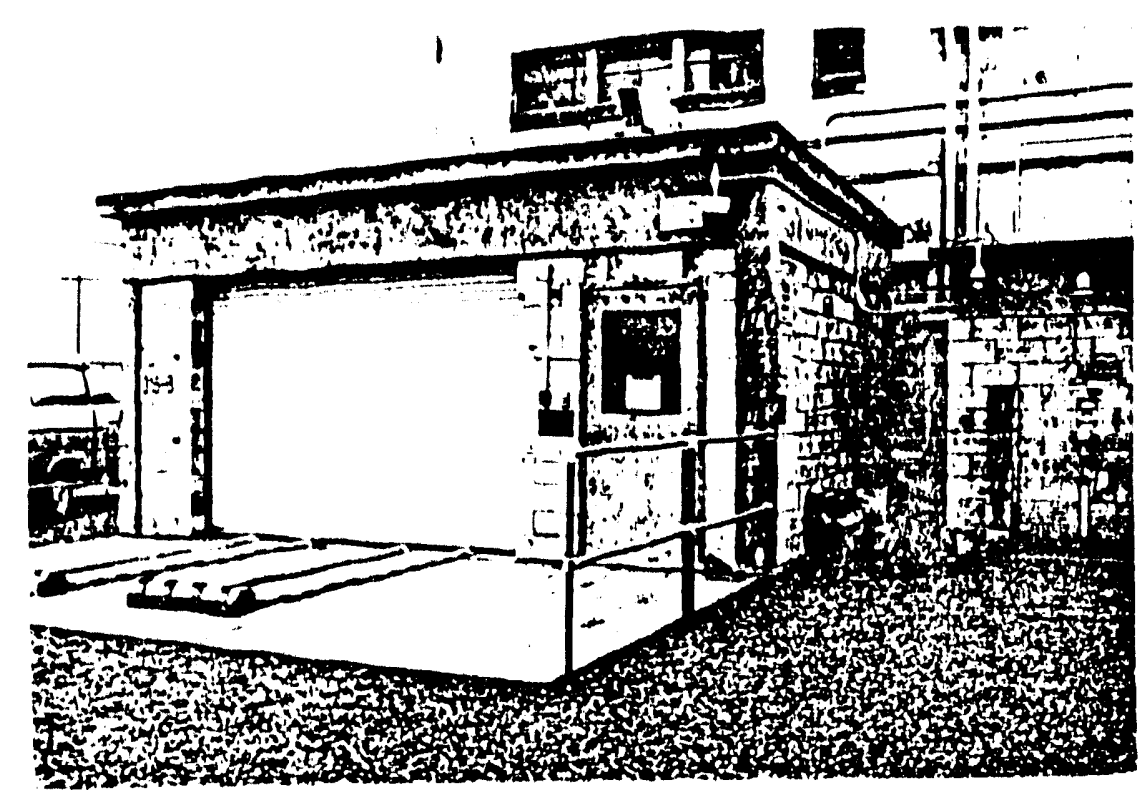

Figure 5. Building Housing Chlorine Cylinders and Chlorination Process Equipment

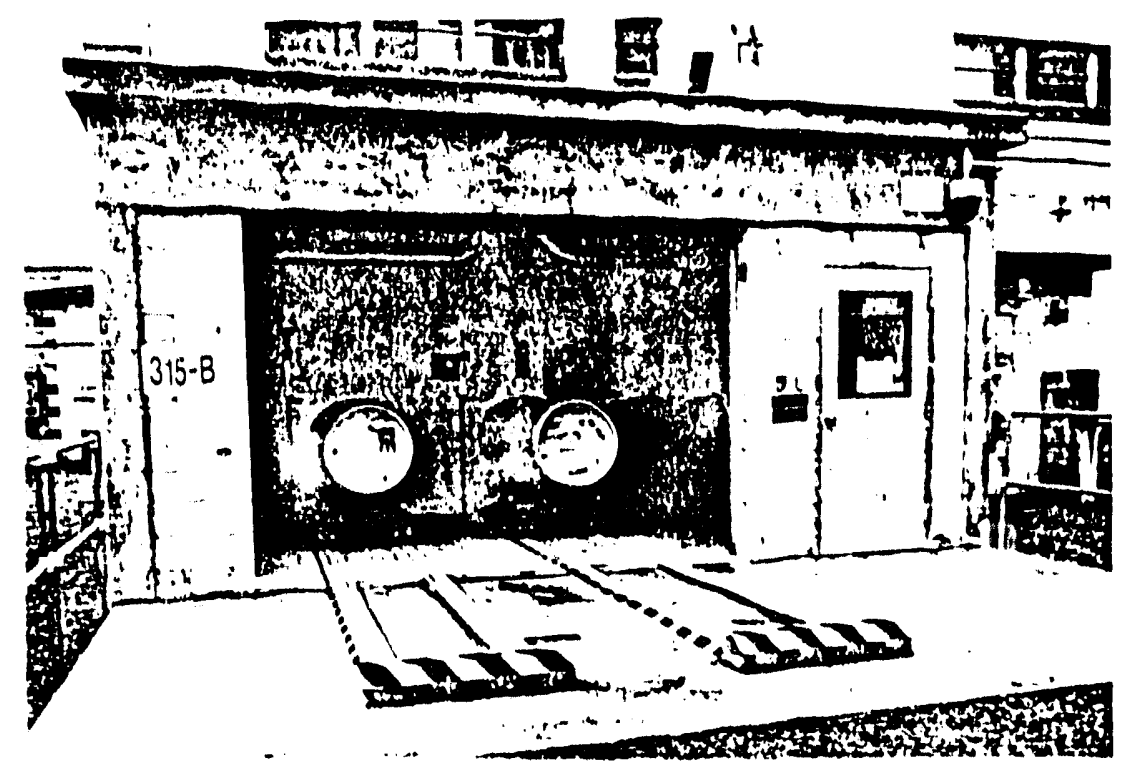

Figure 6. Chlorine Cylinder Storage and Change-out Area, Overhead Door Open 


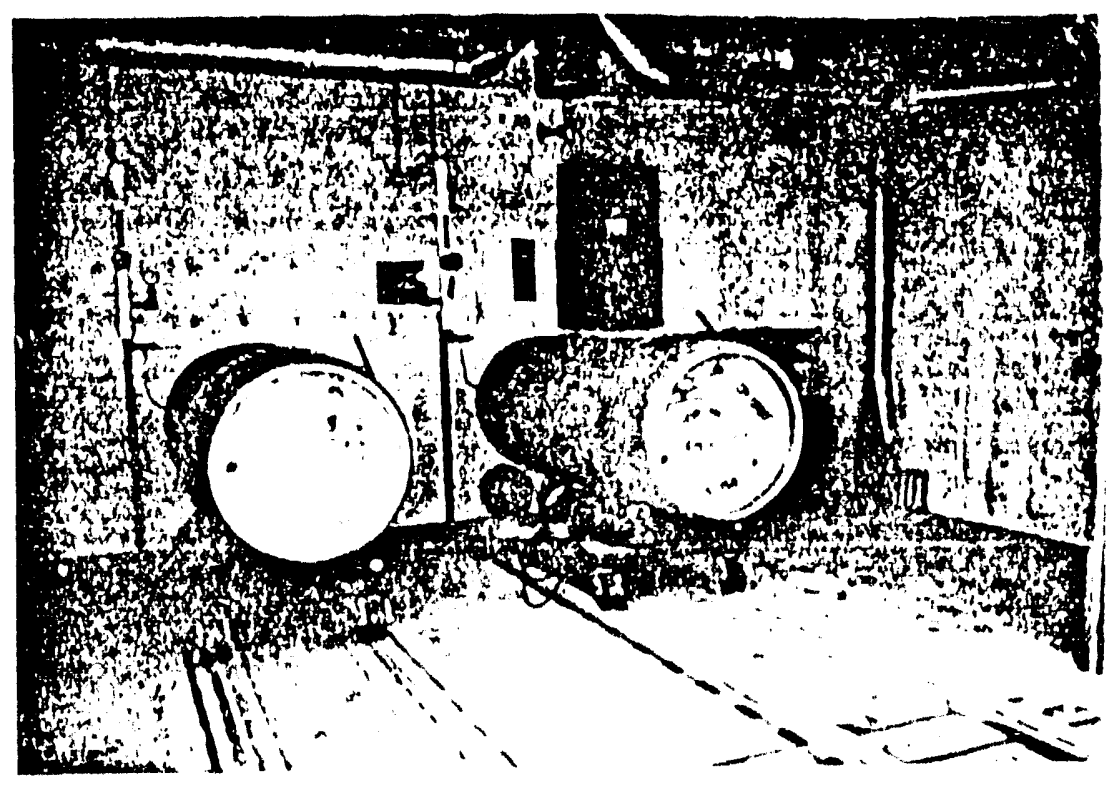

Figure 7. Chlorine Cylunders in the chlorine cylinder Storage Area, front Vieu

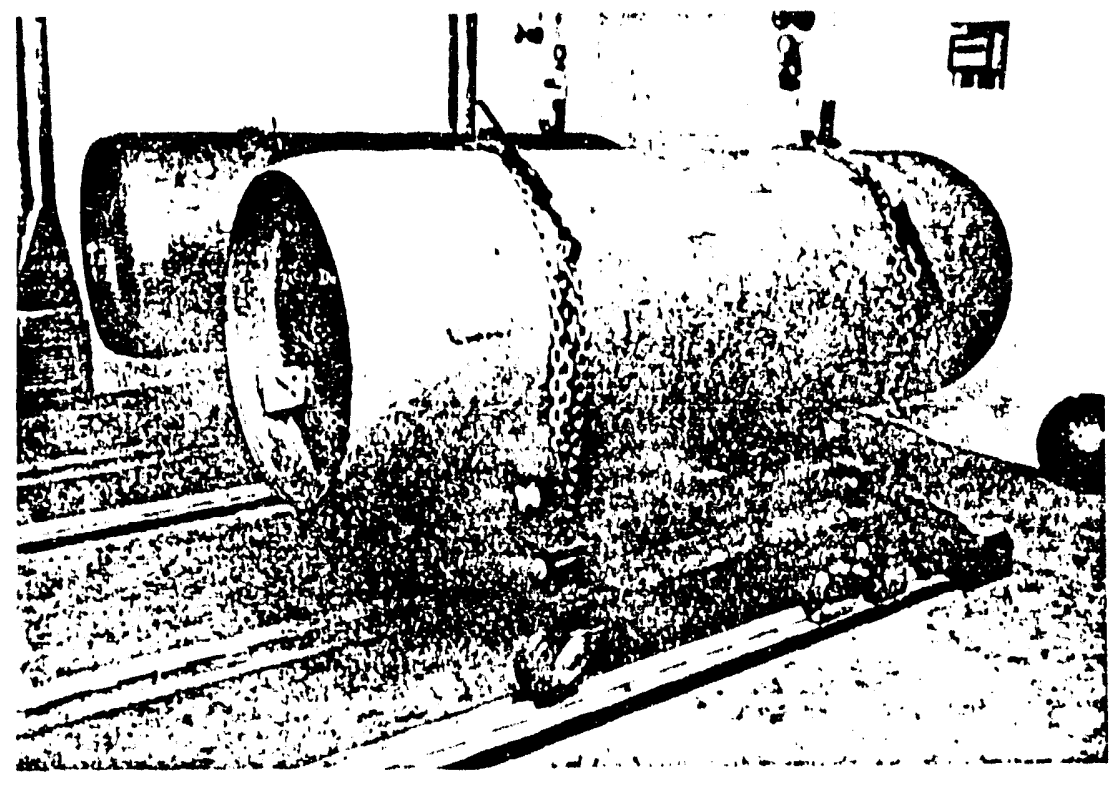

Figure 8. Chlorine Cylinders in the Chlorine Cylinder Storage Area, Side View 


\subsection{REVIEW OF PREVIOUS INCIDENTS}

The following incidents involved the former chlorination system for the Hanford 300Area Water Treatment Facility. Information about these incidents was obtained from the U.S. Department of Energy (DOE) Occurrence Reporting and Processing System (ORPS). Where relevant, these incidents were considered during the hazard and operability (HAZOP) study for the new system.

- 10/9/92 Leak Detector Failure - The leak detector was outside of specified tolerances, as required in the maintenance procedure. Plant operations personnel were notified. Replacement parts were not available, and the maintenance craftsman removed the device from service until parts could be obtained the next day. During the swing and the following day shift, personnel did not know the detector had been removed from service. A "conduct of operations" review of the day's activities was held with all on-coming and off-going staff. This leak detector had experienced recurring failures and was replaced. (See Scenario 5-2 in the HAZOP study worksheets, Appendix B.)

- 11/19/92 Chlorine Leak - The chlorine detector in the chlorination room alarmed in the afternoon, indicating that one of the chlorinators was leaking. Facility operations personnel were evacuated, and the Hanford Fire Department Emergency Response Team was notified. The system was shut down, the in-service chlorinator was isolated, and the standby chlorinator was put into service. No one was injured, and only a minimal amount of chlorine was released. The chlorine was generally confined to the chlorination room. It was determined that the \#1 chlorinator injector system had developed a leak. The system failed because of imperfections within gasket material. The failed material was replaced. (See Scenarios 1-4, 1-10, and 4-9 in the HAZOP study worksheets, Appendix B.)

- 11/21/92 Chlorine Leak - A chlorine alarm was received, the Hanford Fire Department was notified, and the Hanford Hazardous Materials (HAZMAT) Team was dispatched. The Hanford 300-Area Water Treatment Facility was shut down. A tie-in line was put into service to supply water to the Hanford 300-Area from the City of Richland after Richland was notified. Failed internal parts of the \#2 chlorinator and a system isolation valve packing gland were leaking. A weak spring in a chlorinator pressure-regulating valve caused a rubber diaphragm to fail. There were no injuries, and the minimal amount of chlorine released was generally confined to the chlorination room. The spring and diaphragm were replaced. The isolation valve was repacked. (See Scenarios 1-10 and 1-4 in the HAZOP study worksheets, Appendix B.)

- 1/4/93 Chlorine Leak Detector Alarm - While performing routine equipment changes, the on-duty operator noticed a chlorine odor in the chlorination room. After the operator exited, the chlorine leak detector in the building alarmed. The plant operator evacuated the Water Treatment Facility, and the Hanford HAZMAT 
Team responded and isolated the system. The Water Treatment Facility was shut down, and the City of Richland water supply was placed in service. There were no injuries from the occurrence.

During maintenance activity, the operator had isolated and drained the in-service chlorinator according to procedures in effect at the time. These procedures did not allow sufficient time for evacuating the chlorine ejector prior to draining the chlorinator. The system was checked for leaks, but no leaks were found. The procedure was revised to allow sufficient time to evacuate the system. With different procedures now in place, this incident has consequences similar to Scenario $1-11$ in the HAZOP study worksheets (see Appendix B).

- 1/16/93 Chlorine Leak Detection Alarm - A chlorine high-level alarm occurred. The Hanford Fire Department was notified, and several surrounding buildings were evacuated. Testing by the Hanford HAZMAT Team found no detectable chlorine in the air. Fewer than two hours later, the "all clear" was given. It was determined that the detector provided a false alarm. Tests performed by an instrument technician, however, showed that the detector was operating within the manufacturer's recommended tolerances. No leaks were identified when the system was restored to operation.

Prior to the occurrence, re-liquefaction of the gaseous chlorine within the chlorination room piping had been occurring. An additional heat source had been provided to rectify the problem. The heater had been placed next to the leak detector. The detector's electronics were affected by the increased room temperature. A voltage spike was created within the instrument and resulted in the false alarm. (See Scenarios 5-2 and 2-5 in the HAZOP study worksheets, Appendix B, and recommendation \#4 in Section 4.0.) 


\subsection{IDENTIFIED HAZARDS}

Chlorine has been used for many years to treat water on the Hanford Site. Westinghouse Hanford Company uses the Chlorine Manual (The Chlorine Institute, 1986, 5th edition), Operating Procedure: Chlorine Cylinder Handling and Storage (Westinghouse Hanford Company, no date), and the Material Safety Data Sheet (MSDS) (Occupatic nal Health Services, Inc., 1993; see Appendix D) as references for chlorine handling.

\subsection{Properties of Chlorine}

Chlorine is a dense, nonflammable, greenish-yellow gas with a bleach-like choking odor. It is 2.5 times heavier than air. Liquid chlorine is a clear amber color and is 1.5 times heavier than water. Chlorine is generally shipped as a compressed, liquified gas with a vapor pressure of $85.5 \mathrm{psig}$ at $70^{\circ} \mathrm{F}$. In both gaseous and liquid states, chlorine is nonflammable and nonexplosive. However, like oxygen, it is capable of supporting the combustion of substances such as hydrogen, ammonia, fuel gases, ether, turpentine, and most hydrocarbons. Finely divided metals and organic matter may react violently with chlorine. Steel and iron ignite and burn in an atmosphere of chlorine at about $484^{\circ} \mathrm{F}$. Chlorine reacts with water to form corrosive solutions of hydrochloric and hypochlorous acid.

\subsection{Physiological Effects}

Chlorine is corrosive, highly toxic, and severely irritating to all living tissue. Exposure may cause skin burns, permanent eye damage, and damage to the respiratory system. Inhalation exposure to higher concentrations of chlorine may be fatal. Airborne concentrations of chlorine above 3 to 5 parts per million (ppm) by volume are readily detectable by a normal person. In higher concentrations, the irritating effect of chlorine makes it unlikely that any person would willingly remain in a chlorine-contaminated atmosphere.

Persons exposed to airborne concentrations of chlorine greater than $15 \mathrm{ppm}$ generally experience difficulty in breathing. Excessive or prolonged exposure causes pulmonary edema and death. The physiological effects of various concentrations of chlorine gas are shown in Table 2 along with the limits for chlorine exposure in the workplace. Appendix $\mathrm{C}$ includes graphs that estimate the areas affected by various chlorine release scenarios. Exposure to chlorine produces no known cumulative effects. 
Table 2. Physiological Responses and Exposure Limits for Chlorine Gas Concentrations

\begin{tabular}{|l|c|}
\hline \multicolumn{1}{|c|}{ Effects/Limits } & $\begin{array}{c}\text { Parts per Million } \\
\text { (ppm) } \\
\text { by Volume }\end{array}$ \\
\hline Threshold limit value $^{(\mathrm{a})}$ & 0.5 \\
\hline Least detectable odor $^{(\mathrm{b})}$ & 3.5 \\
\hline Least amount required to cause irritation of throat $^{(\mathrm{b})}$ & 15 \\
\hline${\text { Immediately Dangerous to Life or Health (IDLH) } \text { concentration }^{(\mathrm{c})}}$ & 30 \\
\hline Dangerous for short exposures $^{(\mathrm{b})}$ & 50 \\
\hline Fatal for brief exposures $^{(\mathrm{h})}$ & 1,000 \\
\hline
\end{tabular}
(a) American Conference of Governmental Industrial Hygienists, 1992.
(b) Sax, et al., 1979.
(c) National Institute for Occupational Safely and Health, 1990. 


\subsection{ANALYSIS METHOD}

The analysis method used in this example process hazard analysis (PrHA) was the hazard and operability (HAZOP) study. The HAZOP study was developed specifically for process industries to identify both safety hazards and operability problems that could compromise a plant's ability to achieve design productivity.

The basic concept behind HAZOP studies is that processes work well when operating under design conditions, and that deviations from process design conditions cause hazards and lead to operability problems. In a HAZOP study, guide words are used to assist an analysis team in considering the causes and consequences of deviations from design conditions. The guide words are applied at specific points or "nodes" in a process and are combined with process parameters to identify potential deviations.

The HAZOP study method entails analyzing hazardous events (accidents) to see how they may occur and what undesired consequences are possible. Each sequence of failures and conditions leading to an accident event is a unique scenario. Every accident scenario includes an initiating event or cause (e.g., mechanical or human failure), a process deviation(s), an accidental event or consequence, and an impact (injuries and/or damage). Protection may be employed to keep the accident from occurring. Mitigation may reduce the severity of the impact (see Figure 9).

The HAZOP methodology

- Postulates deviations from design intent

- Examines the causes of the deviations

- Determines the consequences and range of potential impacts if deviations are allowed to continue uncorrected

- Assesses the protection included in the system design to reduce the likelihood of the cause and/or to prevent or minimize the consequences or impacts.

A HAZOP study requires considerable knowledge of the process being studied, its instrumentation, and its operation. This information is usually provided by team members who are experts in these areas. Where weaknesses or safety improvements in the design or operating procedures are identified, the HAZOP study team develops a list of action items to be further addressed.

Based on the level of complexity and the general nature of the chlorination process at the Hanford 300-Area, the HAZOP study is an appropriate PrHA method to analyze the hazards of the operation. 
For a more detailed description of the HAZOP study method and other PrHA methods, see the DOE Guideline: Guide For Chemical Process Hazard Analysis (Draft, DOE/EH, March 1993) and the Guideline for Hazand Evaluation Procedures (Center for Chemical Process Safety, 1992, 2nd edition). 


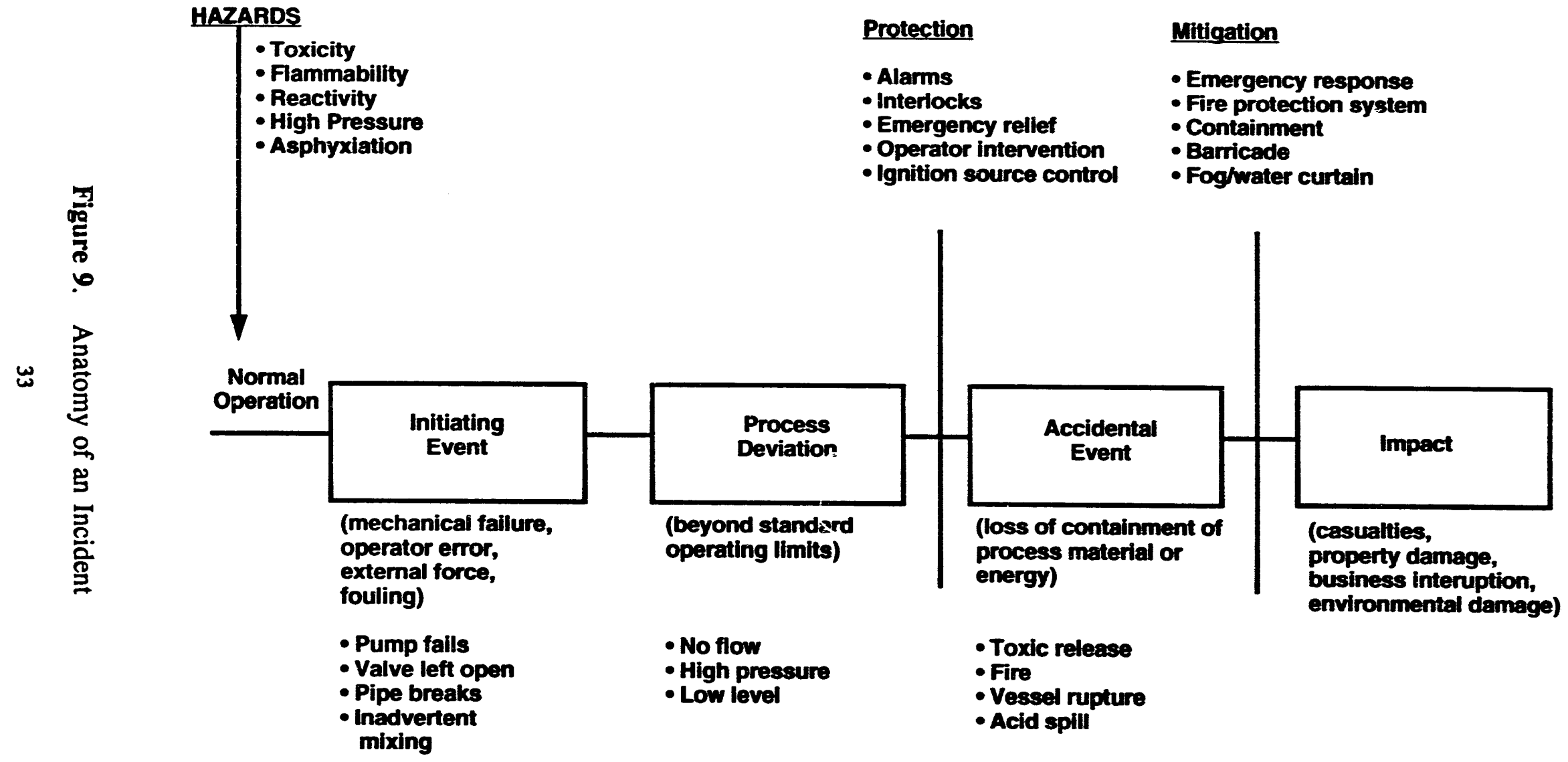




\subsection{ANALYSIS TEAM}

The hazard and operability (HAZOP) study team consisted of the team leader, Mr. Fred Leverenz, from Battelle's Process Safety and Risk Management Group; Westinghouse Hanford Company (WHC) personnel; representatives from the U.S. Department of Energy (DOE) Headquarters and Richland Operations Office; and personnel from the Pacific Northwest Laboratory (PNL) Training Group and Risk and Safety Analysis Group.

Table 3 lists the personnel who participated in the 4-day HAZOP study. Appendix E contains the resumes of the HAZOP study team.

Table 3. HAZOP Study Team Members

\begin{tabular}{|l|l|l|}
\hline \multicolumn{1}{|c|}{ PARTICIPANT } & \multicolumn{1}{|c|}{ ORGANIZATION } & \multicolumn{1}{c|}{ ROLE } \\
\hline Fred Leverenz & Battelle-Columbus & PrHA Expert and Team Leader \\
\hline Karl Agee & Westinghouse Hanford Company & Team Memher \\
\hline Joe Angyus & Pacific Northwest Laburatory & Team Memher \\
\hline Samuel Camp, Jr. & Westinghouse Hanford Company & $\begin{array}{l}\text { Process Operator and Team } \\
\text { Member }\end{array}$ \\
\hline Rudy Hansen & Pacific Northwest Laboratory & Scribe \\
\hline Sanji Kanth ${ }^{*}$ & DOE Headquarters & Team Member \\
\hline Ken Murphy & DOE Headquarters & Team Memher \\
\hline Dickie Ortiz & DOE Richland Operations Office & Team Member \\
\hline Pete Pelto & Pacific Northwest Laboratory & Team Member \\
\hline John Piatt & Pacific Northwest Laboratory & Team Member \\
\hline Jay Rude & Westinghouse Hanford Company & $\begin{array}{l}\text { Process Engineer and Team } \\
\text { Member }\end{array}$ \\
\hline
\end{tabular}

* Partial attendance 


\subsection{FACILITY SITING ANALYSIS}

As part of the process hazard analysis (PrHA), a walkdown of the Hanford 300-Area Water Treatment Facility was performed on May 22, 1993. The following is a description of the general layout of the facility.

The Hanford 300-Area Water Treatment Facility is located within the fences of the Hanford 300-Area and away from offsite populations. Most near-by human activities are related to facility operations and/or chlorine delivery and associated crane manipulations.

The Columbia River is directly east of the Water Treatment Facility. The closest residences are isolated houses on the opposite side of the river, more than three-quarters of a mile away. A pump house is located east of the facility near the river. The east access road, which supports only low levels of traftic, is more than 120 feet away, at a lower elevation.

The chlorination room ( 80 square feet) and the chlorine cylinder storage area (300) square feet) are on the north side of the 315 Building. The building closest to the chlorination process is the 338 Maintenance Shop. It is more than 60 feet to the west of the chlorination room. This building is being transferred from the Westinghouse Hanford Company (WHC) to Kaiser Engineers, Inc., to be used as a fabrication shop. About 20 to 40 employees will eventually occupy the building.

Other buildings in the vicinity of the chlorination process are the 337 Office Building (325 employees), which is more than 200 feet to the south, and the 3768 Modular Office Building (15 employees), which is more than 150 feet to the north. To the north of the 3768 Building are the 3769 Modular Office Building (15 employees), the M103 trailer (7 employees), the M105 trailer (9 employees), and the 3770 Modular Office Building (15 employees). All buildings have multiple exits and emergency plans. The emergency plan evacuation route for the 337 Office Building is toward the south, away from the chlorination process. The emergency plan addresses leaks and spills, as well as unusual, irritating, or strong odors.

The regulator for the chlorine cylinders vents near the roof level of the chlorine cylinder storage area. Shutoffs (G1 and G2) for the chlorine feed are inside the storage area. See Appendix $\mathrm{C}$ for potential impacts of chlorine releases. 


\subsection{HUMAN FACTORS}

The Occupational Safety and Health Administrative (OSHA) rule on process safety management (the PSM Rule) requires the inclusion of human factors in process hazard analyses (PrHAs). Human factors may positively or negatively influence the likelihood of an operator making an error when interacting with a process. For example, if an operator is required to change the position of a valve, but the location of the valve is not specifled and/or the valve is not labeled, the operator may have difficulty responding correctly. More positively, if an operator has enough time to complete an action such that he/she can verify the action, then it is more likely that the operator will act correctly.

Human factors are included in this hazard and operability (HAZOP) study by adding notations in the CAUSE or PROTECTION column of the HAZOP study worksheets (see Appendix B) immediately after a human error is indicated. The notation used is " $-\mathrm{HF}^{\prime}$ for human factors that may negatively influence an operator's performance and " $+\mathrm{HF}^{\text {" for human }}$ factors that may help an operator to act correctly.

In some places in the HAZOP study worksheets, human interactions/errors are indicated, but no notation is present. If no human factors notiflcations are present, the HAZOP study team judged that the human factors components of that scenario were "normal," expected good practice. For example, the HAZOP study team assumed that all equipment was labeled.

Table 4 provides a generic checklist for human factors. This list is recommended for use by PrHA teams to help recognize the human factors that influence each accident scenario. 
Table 4. Human Factors Checklist

\begin{tabular}{|c|c|c|}
\hline FACTORS & EXPECTED (+) & NEGATIVE (-) \\
\hline \multirow[t]{6}{*}{ DISPLAYS/CONTROLS } & Easy to read/understand & Hard to read/understand/interpret \\
\hline & Controls accessible & Controls inaccessible \\
\hline & Display identifies related device & Display does not show device \\
\hline & Alurms discriminable, relevunt & Alarms confusing, irrelevant \\
\hline & Display mimics action/position & Display is not representational \\
\hline & Immediate feualhack & No immediate feedhack \\
\hline \multirow[t]{4}{*}{ EQUIPMENT } & Clearly labeled & Not labeled or mislabiled \\
\hline & Accessible & Nol ensily accessied \\
\hline & Eusily operated & Difficult lo operate/change position \\
\hline & Components easy to distinguish & Several components look similar \\
\hline \multirow[t]{5}{*}{ PROCEDU/RES } & Rualistic; reflect the way things are done & Unrealistic; not the way things are done \\
\hline & Lexition of devices/action provided & No location of devices/action provided \\
\hline & $\begin{array}{l}\text { Allows unumbiguous determinution of } \\
\text { event in progress }\end{array}$ & Results in inuppropriate diagnessis \\
\hline & Clear, consistent format & Confused, difticult to rend \\
\hline & romplete and accurate & $\begin{array}{l}\text { Missing step in procedure or wrong } \\
\text { sufuence }\end{array}$ \\
\hline \multirow[t]{5}{*}{ COMPETENCE } & $\begin{array}{l}\text { Operators generally well trained in related } \\
\text { procedures }\end{array}$ & $\begin{array}{l}\text { Operators not well trained in related } \\
\text { procedures }\end{array}$ \\
\hline & Operators have considerable experience & Operators are novices \\
\hline & Peer review used in certification & No peer review in certification \\
\hline & $\begin{array}{l}\text { Operators given periodic fuedhack on } \\
\text { performance }\end{array}$ & No feecelhack \\
\hline & $\begin{array}{l}\text { Design changes are appropriately } \\
\text { reviewed }\end{array}$ & $\begin{array}{l}\text { Design changes performed without } \\
\text { adequate review }\end{array}$ \\
\hline
\end{tabular}


Table 4. Human Factors Checklist (Continued)

\begin{tabular}{|c|c|c|}
\hline FACTORS & EXPECTED (+) & NEGATIVE (-) \\
\hline \multirow[t]{6}{*}{ STRFSS } & $\begin{array}{l}\text { Adequate time available to complete } \\
\text { action }\end{array}$ & $\begin{array}{l}\text { Too little time available to complete } \\
\text { action }\end{array}$ \\
\hline & $\begin{array}{l}\text { Shift assignments are permanent, or shift } \\
\text { changes do not create time confusion }\end{array}$ & $\begin{array}{l}\text { Shin changes often occur in the middle } \\
\text { of the week; double shifts often occur }\end{array}$ \\
\hline & Staffing is at an appropriate lovel & $\begin{array}{l}\text { Staff are needed, or some shifts aro } \\
\text { intentionally short-staffed }\end{array}$ \\
\hline & Safoty is emphasized & $\begin{array}{l}\text { Operators are concernod about loss of } \\
\text { production if plant inadvertently shut } \\
\text { down for safoty issue }\end{array}$ \\
\hline & Accountabilities aro well defined & Accountabilities are poorly defined \\
\hline & $\begin{array}{l}\text { Operator performs acceptable number of } \\
\text { tasks }\end{array}$ & $\begin{array}{l}\text { Operator must conduct diverse operations } \\
\text { within sume time period }\end{array}$ \\
\hline \multirow{6}{*}{$\begin{array}{l}\text { ENVIRONMENT/ } \\
\text { WORKPLACE }\end{array}$} & Sufficient lighting & Inadequate lighting \\
\hline & Minimal noise level & High noike level \\
\hline & Moderate weather & Extreme weather conditions \\
\hline & Comfortable temperature/humidity & Extreme lemperature/humidity \\
\hline & Low vibration environment & High vibration environment \\
\hline & Good job aids & No memory support \\
\hline
\end{tabular}




\subsection{SUMMARY}

During the process hazard analysis (PrHA) of the chlorination process at the Hanford 300-Acre Water Treatment Facility, areas of uncertainty were identified. Twelve action items and recommendations were made by the PrHA team to clarify these uncertainties and to verify process conditions (see Section 4.0). These recommendations are being reviewed to determine whether further action is needed to improve the chlorination system. In addition, procedures were developed during the PrHA exercise to control and avoid potential hazards.

To comply with the Occupational Safety and Health Administration (OSHA) rule on process safety management (the PSM Rule), all of the PrHA findings and recommendations must be resolved and documented. All actions taken as a result of the PrHA findings must be reported to cmployees involved in the process and to any other affected individuals. In addition, the PrHA must be reviewed every 5 years to ensure that it is consistent with the current conflguration and operation of the chlorination process. The PrHA, related updates, and the documented resolution of the recommendations must be maintained for the life of the process. 


\subsection{REFERENCES AND BIBLIOGRAPHY}

American Conference of Governmental Industrial Hygienists. 1992-1993 Threshold Limit Values for Chemical Substances and Physical Agents and Biological Exposure Indices, Cincinnati, OH, 1992.

Capital Controls Co. Inc. Instruction Manual: Cabinet Mounted Gas Feeders, Manual/Automatic Control, Series 4000, Bulletin B3.84000.2, Colmar, PA, 1992.

Capital Controls Co. Inc. Operation and Maintenance Manual for Westinghouse Hanford Company, CCC\# C722730. Series of Bulletins A2.41101.1, A2.62105.4, A2.60000.4, $\mathrm{A} 2.41002 .0, \mathrm{~A} 2.41701 .0, \mathrm{~A} 2.41009 .0, \mathrm{~A} 2.41410 .2, \mathrm{~A} 1.14100 .7, \mathrm{~B} 3.84000 .2, \mathrm{~A} 1.11450 .1$, B3.71051.1, B3.7858.8, B3.7859.3, B3.7854.2, B3.7860.5, B3.71018.4, B3.71049.0, B3.7147.11, B3.7135.18, B3.7133.7, B3.7814.4, and B3.7193.11, Richland, WA, 1993.

Center for Chemical Process Safety. Guidelines for Hazard Evaluation Procedures, 2nd Edition, American Institute of Chemical Engineers, New York, NY, 1992.

The Chlorine Institute, Inc. Chlorine Manual, 5th Edition, Washington, DC, 1986.

The Chlorine Institute, Inc. Pamphlet 17: Cylinder and Ton Container Procedure for Chlorine Packaging, 2nd Edition, Washington, DC, 1993.

The Chlorine Institute, Inc. Pamphlet 74: Estimating the Area Affected by a Chlorine Release, 2nd Edition, Washington, DC, 1991.

Merck \& Co., Inc. The Merck Index, an Encyclopedia of Chemicals and Drugs, 9th Edition, Rathway, NJ, 1976.

National Institute for Occupational Safety and Health. NIOSH Pocket Guide to Chemical Hazards, U.S. Department of Health and Human Services, Public Health Service, Centers for Disease Control, Cincinnati, OH, June 1990.

Occupational Health Services, Inc. Material Safety Data Sheet: Chlorine, OHS-04600, New York, NY, 1993.

Sax, N. Irving, et al. Dangerous Properties of Industrial Materials, 5th Edition, Van Nostrand Reinhold, New York, NY, 1979.

U.S. Code of Federal Regulations. Process Safety Management of Highly Hazandous Chemicals, 29 CER 1910.119, Occupational Safety and Health Administration, Washington, DC, 1992. 
U.S. Department of Energy. DOE Guideline: Preliminary Guide for Conformance with OSHA's Rule for Process Safety Management of Highly Hazardous Chemicals, Draft, DOE/EH, Washington, DC, March 1993.

U.S. Department of Energy. DOE Guideline: Guide for Chemical Process Hazard Analysis, Draft, DOE/EH, Washington, DC, March 1993.

Westinghouse Hanford Company. Operating Procedure: Chlorine Cylinder Handling and Storage, WHC-IP-384, SW U3-0-315-20, Richland, WA, no date.

Zimmerman, R.O. Assessment of Chlorine Release From One-Ton Containers, TC-1772, Hanford Engineering Development Laboratory, Richland, WA, 1980. 


\section{APPENDIX A}

\section{PROCEDURES FOR CHANGE-OUT OF CHLORINE CYLINDERS}




\section{APPENDIX A: PROCEDURES FOR CHANGE-OUT OF CHLORINE CYLINDERS}

\section{PART I: Removal of Cylinder}

\section{Assumptions:}

- $\quad$ Replace west cylinder with chlorinator $\# 1$ in service (valves $G 3, G 8, G 4, S 2$, W4, G10, G11, and G12 are closed to supply chlorinator \#1).

- Serviceman and operator wear coveralls.

1. Notify the 384 Powerhouse and the Hanford Fire Department that the chlorine cylinder change-out is in progress.

2. Start the 315B Building vent fan and operate it for three (3) minutes before entering. Maintain the vent fan continuously. (Alarms operate at 1 and $5 \mathrm{ppm}$. )

3. Enter through the walk-through door.

4. Identify the empty cylinder by its weight, and verify the indication of no flow on the cylinder regulator.

5. Close the angle (root) valve on the chlorine cylinder.

6. Isolate the automatic switchover valve. (Close valves G5, G6, and G9.)

7. Verify that valves G8 and G4 are closed.

8. Verify that valve G1 is open, and open valve G3. Wait two (2) minutes and verify that there is no flow at the chlorinator in service. Verify that the high-vacuum alarm is actuated.

9. Close valves $\mathrm{G} 1$ and G3. Open valves G6 and G9, and verify that the high-vacuum alarm clears.

10. Chlorine serviceman dons the facemask, and operator dons self-contained breathing apparatus (SCBA). Then they verify the operation of the personal protective equipment.

11. Slowly disconnect the regulator, check it for leaks, and set it on the floor. 
12. Install the cap on the cylinder angle valve, and install the protective hood.

13. Position the crane and cylinder truck for loading; open the roll-up door; remove the chocks; and push the cylinder out to the stops.

14. Release the chain binders, and turn the cylinder over to the hoist and rigging crew.

15. Install the spreader bar, lift the cylinder, and place it on the flatbed truck.

16. Secure the cylinder and transport it.

17. Close the roll-up door, and exit through the walk-through door. 


\section{PART II: Installation of Replacement Cylinder}

1. Turn on or verify that the storage room exhaust fan is on.

2. Position the crane for unloading.

3. Position the chlorine transport truck for unloading.

4. Verify that the chlorine cylinder trolley is in position to receive the cylinder.

5. Release the cylinder binder(s) on the transport vehicle.

6. Install the lifting bar, and lift the cylinder.

7. Place the cylinder on the trolley.

8. Remove the lifting bar, removing it from the immediate area.

9. Secure the cylinder to the trolley with chain binders (2).

10. Enter through the walk-through door, and open the roll-up door.

11. Push the trolley and the chlorine cylinder into the building and against the rail stop. Install the wheel chocks.

12. Request the chlorine serviceman to remove the protective hood from the chlorine cylinder.

13. Observe the position of the cylinder angle valves. If the valves are not in vertical alignment, loosen the chain binders and rotate the cylinder to obtain vertical alignment of the valves, and then tighten the chain binders.

14. Chlorine serviceman dons the facemask respirator, and operator dons self-contained breathing apparatus (SCBA) equipment. Then they verify the operation of the personal protective equipment.

15. Verify that the chlorine cylinder gas angle valve is closed.

16. Check for leaks while slowly removing the protective cap from the cylinder gas angle valve.

17. Clean the sealing surface of the gas angle valve and the vacuum regulator. Visually inspect the regulator valve body for damage. 
18. Install a new lead seal. Attach the regulator to the cylinder gas valve, and secure it in place by tightening the yoke assembly.

19. Check for leaks. Slowly open the chlorine cylinder gas supply valve.

20. Adjust the cylinder weight scale to indicate 2,000 pounds of product available in the cylinder.

21. Open system supply valves G1 and G5.

22. Record in the log book the chlorine cylinder identification number and the scale weight.

23. Report any deficiencies to the supervisor for initiation of necessary corrective action.

24. Notify the Hanford Fire Department and the 384 Powerhouse that the chlorine cylinder change-out activities are complete.

25. Close the roll-up door, and exit through the walk-through door. 
APPENDIX B

\section{HAZOP STUDY WORKSHEETS}




\section{APPENDIX B: HAZOP STUDY WORKSHEETS}

Two independent chlorination systems are installed at the Hanford 300-Area Water Treatment Facility. These systems can be operated separately or in parallel. Because they are normally operated separately, this HAZOP study assumes only chlorination system \#1 is operating, and that valves G-12, G-11, G-10, G-8, G-4, G-3, S-2, and W-4 are closed.

The following worksheets document the HAZOP study. The chlorination process was separated into four study nodes. These four nodes are shown on Figure B-1 (Nodes 2 and 4) and Figure B-2 (Nodes 1, 3, and 4). Nodes 5 and 6 cover the procedures for change-out of chlorine cylinders (see Appendix A).

The HAZOP worksheets for the six nodes use HAZOP guide words to determine possible deviations from process design conditions. Causes are described, including positive and negative human factors influences (" $+\mathrm{HF}$ " for positive influences and " $-\mathrm{HF}^{\text {" for }}$ negative influences). Consequences of accident scenarios are estimated qualitatively for each process deviation. Protection and mitigating factors are described, including positive and negative human factors influences. The action/comment column includes both action items and justifications for no further action. 


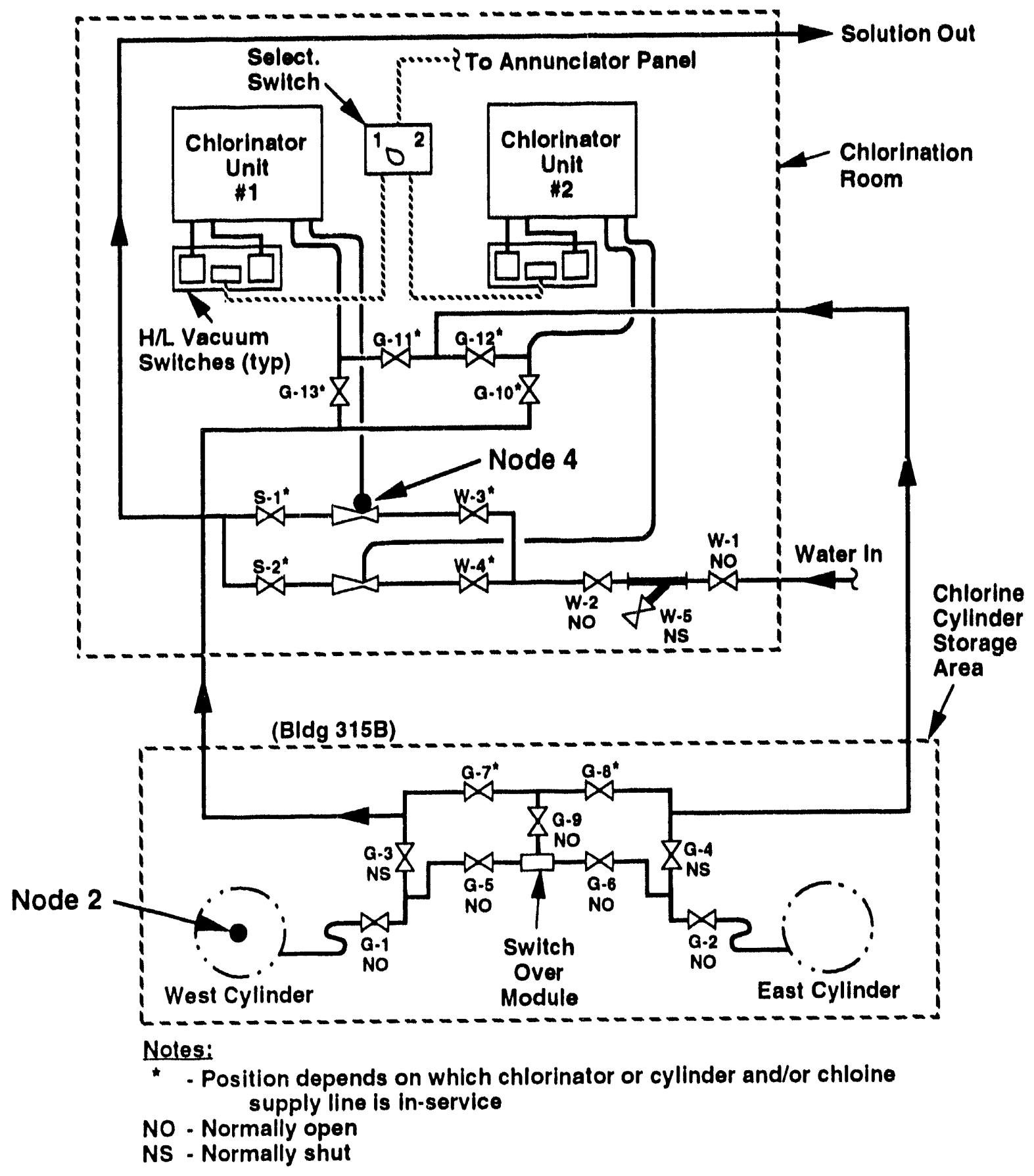

$39306007.1 \mathrm{~A}$

Figure B-1. Chlorination Process, Study Nodes 2 and 4 


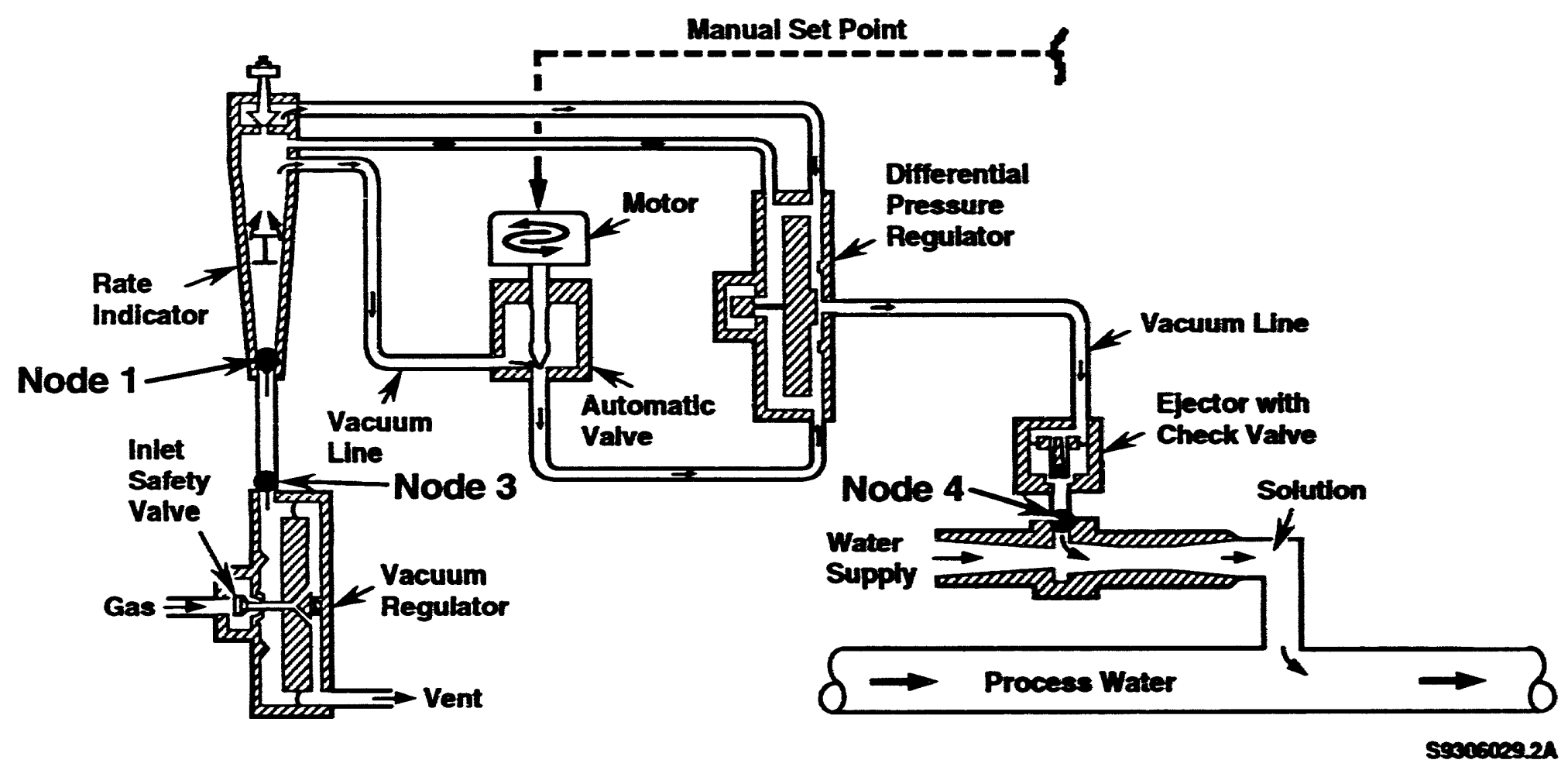




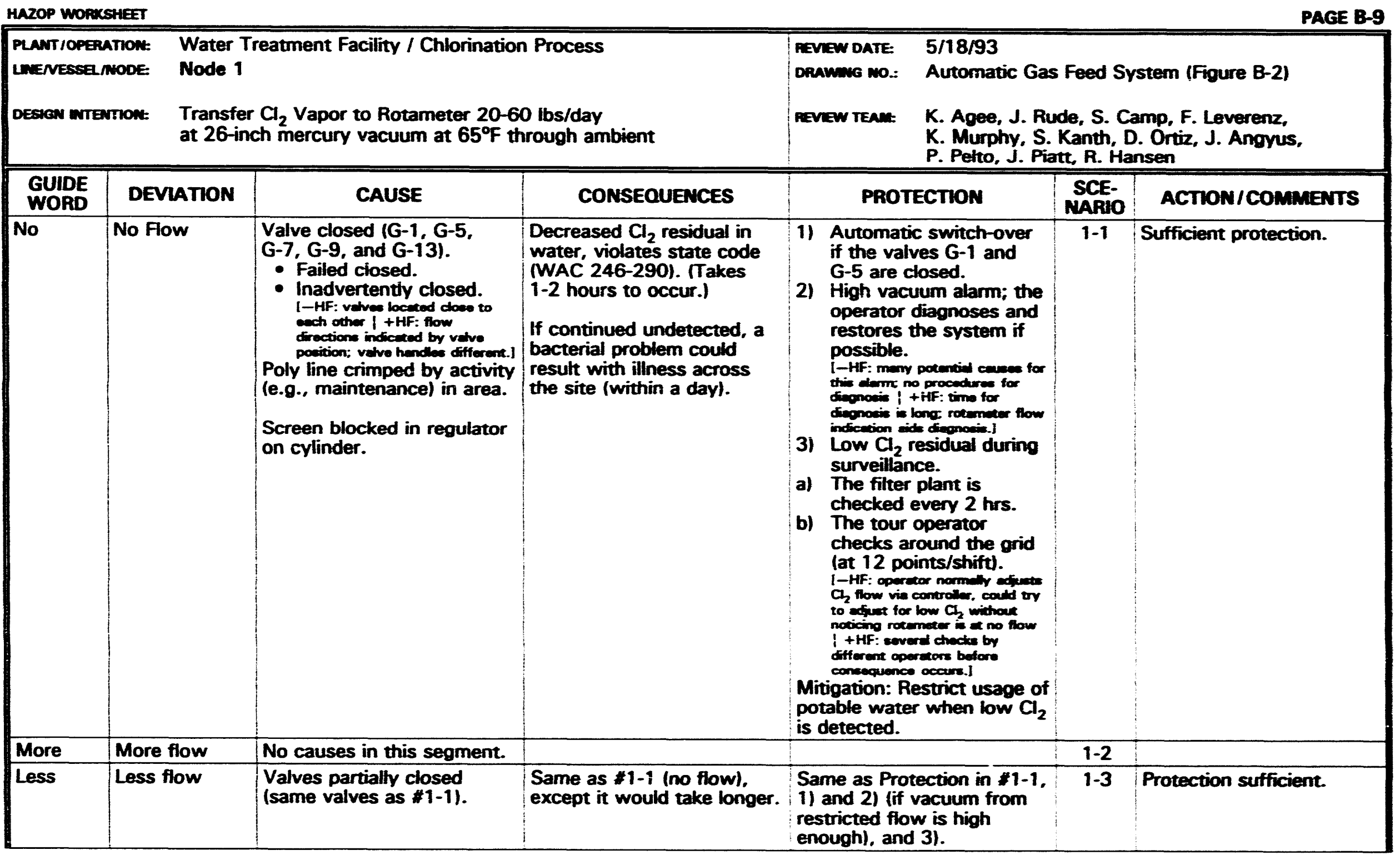




\begin{tabular}{|c|c|c|c|c|c|c|c|}
\hline $\begin{array}{l}\text { PLANT /OPERATIONE: } \\
\text { LMENESSE MNODE: } \\
\text { DESTGN WTEMTION: }\end{array}$ & \multicolumn{3}{|c|}{$\begin{array}{l}\text { Water Treatment Facility / Chlorination Process } \\
\text { Node } 1 \\
\text { Transfer } \mathrm{Cl}_{2} \text { Vapor to Rotameter } 20-60 \mathrm{lbs} / \text { day } \\
\text { at } 26 \text {-inch mercury vacuum at } 65^{\circ} \mathrm{F} \text { through ambient }\end{array}$} & \multicolumn{4}{|c|}{ 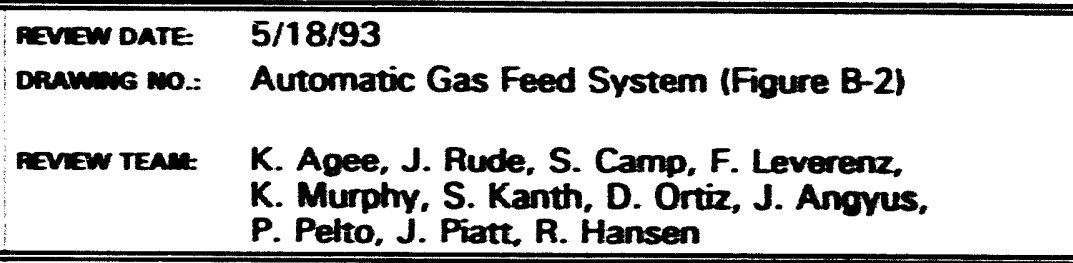 } \\
\hline $\begin{array}{l}\text { GUIDE } \\
\text { WORD } \\
\end{array}$ & DEVIATION & CAUSE & CONSEQUENCES & PRO & ECTION & $\begin{array}{l}\text { SCE- } \\
\text { NARIO }\end{array}$ & ACTION/CONmExts \\
\hline Reverse & Reverse flow & 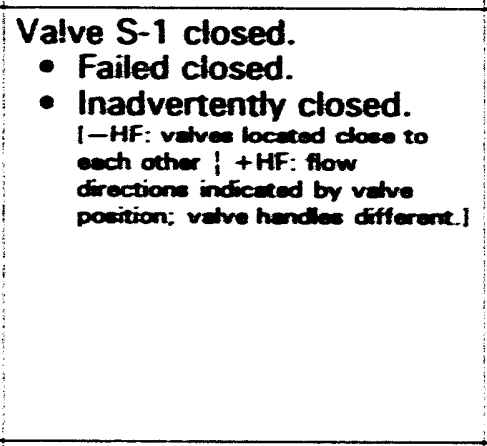 & $\begin{array}{l}\text { Water enters the chlorine } \\
\text { vapor system with damage } \\
\text { to equipment and seals and } \\
\text { there is potential for leaks } \\
\text { later if it is not repaired: } \\
\text { - "In" leakage of air when } \\
\text { operating ejector } \\
\text { - Small "out" leakage of } \\
\mathrm{Cl}_{2} \text { when vacuum from } \\
\text { ejector is interrupted; } \\
\text { minor irritation if staff } \\
\text { present. }\end{array}$ & 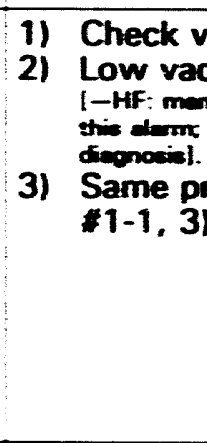 & $\begin{array}{l}\text { Ive at ejector. } \\
\text { um alarm. } \\
\text { potantid caves for } \\
\text { tection as }\end{array}$ & $1-4$ & $\begin{array}{l}\text { Check on possibility of } \\
\text { backfiow past rotameter } \\
\text { and respond accordingly } \\
\text { by modifying } \\
\text { administrative procedures. }\end{array}$ \\
\hline More & $\begin{array}{l}\text { High } \\
\text { Temperature }\end{array}$ & No causes in this segment. & & & & $1-5$ & \\
\hline Less & $\begin{array}{l}\text { Low } \\
\text { temperature }\end{array}$ & $\begin{array}{l}\text { No causes for temperature } \\
\text { low enough to cause a } \\
\text { problem. }\end{array}$ & & & & $1-6$ & \\
\hline More & High pressure & No causes in this segment. & & & & $1-7$ & \\
\hline Less & Low pressure & No causes in this segment. & & & & $1-8$ & \\
\hline $\begin{array}{l}\text { As well } \\
\text { as }\end{array}$ & Air into $\mathrm{Cl}_{2}$ & $\begin{array}{l}\text { Leak in polyethylene } \\
\text { tubing/pipe, valve stem, } \\
\text { etc. } \\
\text { (Replacement of tubing } \\
\text { every two years reduces } \\
\text { the tikelihood of failure.) } \\
\text { Potential for dissimilar } \\
\text { material to thermally } \\
\text { expand or contract from } \\
\text { temperature extremes. }\end{array}$ & $\begin{array}{l}\text { Low } \mathrm{Cl}_{2} \text { for water } \\
\text { treatment. } \\
\text { If continued undetected, a } \\
\text { bacterial problem could } \\
\text { result with illness across } \\
\text { the site. }\end{array}$ & 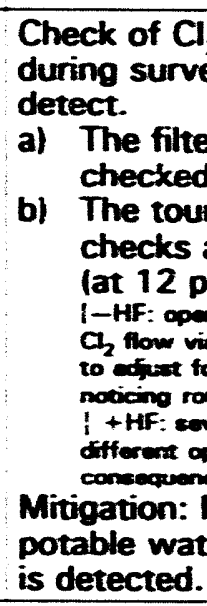 & 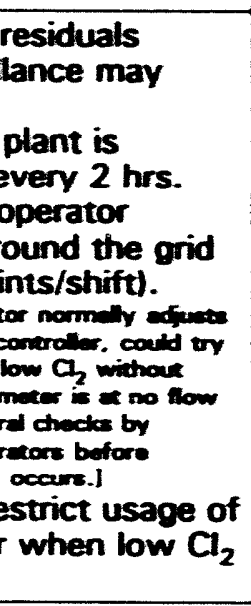 & $1-9$ & $\begin{array}{l}\text { Consider adding } \\
\text { procedures that verify the } \\
\text { vacuum holds after } \\
\text { system shutdown (to be } \\
\text { use when tubing is } \\
\text { replaced and chlorinators } \\
\text { are changed each month). }\end{array}$ \\
\hline
\end{tabular}




\begin{tabular}{|c|c|c|c|c|c|c|c|c|}
\hline \multicolumn{2}{|c|}{$\begin{array}{l}\text { PLANT /OPERATION: } \\
\text { LUENESSEI MODE: } \\
\text { DESTCN NTENTION: }\end{array}$} & \multicolumn{3}{|c|}{$\begin{array}{l}\text { Water Treatment Facility / Chlorination Process } \\
\text { Node } 1 \\
\text { Transfer } \mathrm{Cl}_{2} \text { Vapor to Rotameter } 20-60 \text { lbs/day } \\
\text { at } 26 \text {-inch mercury vacuum at } 65^{\circ} \mathrm{F} \text { through ambient }\end{array}$} & \multicolumn{4}{|c|}{ 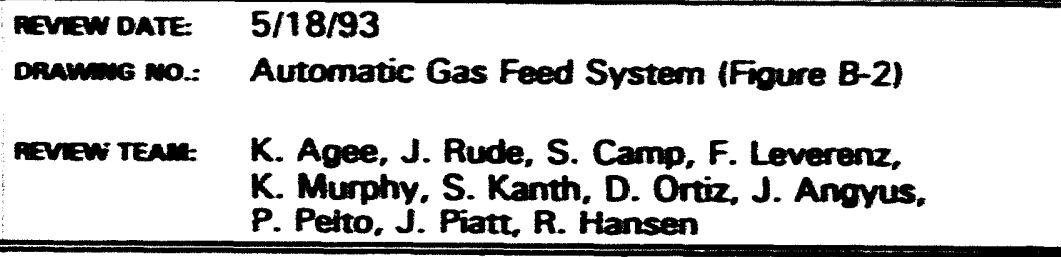 } \\
\hline $\begin{array}{l}\text { GUIDE } \\
\text { WORD }\end{array}$ & DEV & LATION & CAUSE & CONSEQUENCES & PRO & ECTION & $\begin{array}{l}\text { SCE- } \\
\text { MAPOO }\end{array}$ & ACTION/COMAETTS \\
\hline \multirow[t]{2}{*}{$\begin{array}{l}\text { As well } \\
\text { as (cont.) }\end{array}$} & \multirow{2}{*}{\multicolumn{2}{|c|}{ Air into $\mathrm{Cl}_{2}$}} & $\begin{array}{l}\text { Leak in polyethylene } \\
\text { tubing/pipe. valve stem, } \\
\text { etc. } \\
\text { (Replacement of tubing } \\
\text { every two years reduces } \\
\text { the likelihood of failure.) } \\
\text { Potential for dissimilar } \\
\text { material to thermally } \\
\text { expand or contract from } \\
\text { temperature extremes. }\end{array}$ & $\begin{array}{l}\text { Potential for damage to } \\
\text { seals/corrosion from } \mathrm{HCl} \\
\text { forming due to moisture in } \\
\text { air. } \\
\text { Same as } \# 1-4 \text {. }\end{array}$ & \multicolumn{2}{|c|}{ 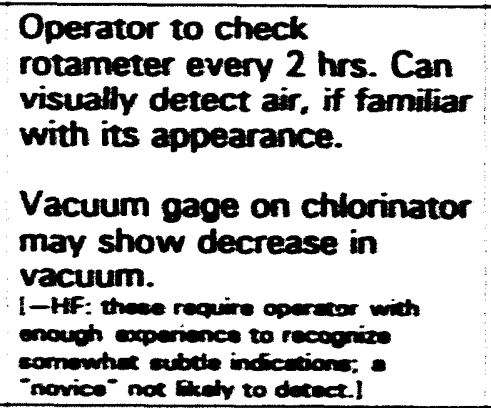 } & $1-10$ & Minor consequences. \\
\hline & & & 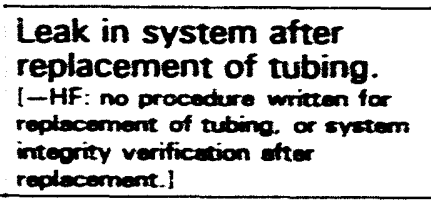 & Same as $\# 1-9$ and $\# 1-10$ & \multicolumn{2}{|c|}{ Same as $1-9$ and $\$ 1-10$} & $1-11$ & Same as $\$ 1-9$ and $\$ 1-10$. \\
\hline Part of & \multicolumn{2}{|c|}{$\begin{array}{l}\text { No meaningful } \\
\text { deviations }\end{array}$} & & & & & & \\
\hline
\end{tabular}




\begin{tabular}{|c|c|c|c|c|c|c|c|c|}
\hline \multicolumn{2}{|c|}{$\begin{array}{l}\text { PLANT/OPERATIONE: } \\
\text { LEENESSE MODE: } \\
\text { DESTGM ETREMTION: }\end{array}$} & \multicolumn{3}{|c|}{$\begin{array}{l}\text { Water Treatment Facility / Chlorination Process } \\
\text { Node } 1 \\
\text { Transfer } \mathrm{Cl}_{2} \text { Vapor to Rotameter } 20-60 \mathrm{lbs} / \text { day } \\
\text { at } 26 \text {-inch mercury vacuum at } 65^{\circ} \mathrm{F} \text { through ambient }\end{array}$} & 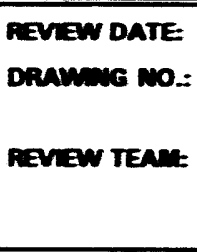 & \multicolumn{3}{|c|}{$\begin{array}{l}\text { 5/18/93 } \\
\text { Automatic Gas Feed System (Figure B-2) } \\
\text { K. Agee, J. Rude, S. Camp, F. Leverenz, } \\
\text { K. Murphy, S. Kanth, D. Ortiz, J. Angvus, } \\
\text { P. Pelto, J. Piatt, R. Hansen }\end{array}$} \\
\hline $\begin{array}{l}\text { GUIDE } \\
\text { WORD }\end{array}$ & & MATION & CAUSE & CONSEQUENCES & \multirow{2}{*}{\multicolumn{2}{|c|}{ 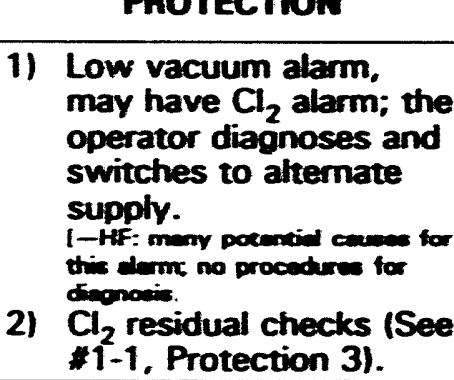 }} & $\begin{array}{l}\text { SCE- } \\
\text { NAPHO }\end{array}$ & ACTION/COMments \\
\hline \multirow[t]{2}{*}{$\begin{array}{l}\text { Other } \\
\text { than }\end{array}$} & \multirow{2}{*}{\multicolumn{2}{|c|}{ Air into ejector }} & \multirow[t]{2}{*}{$\begin{array}{l}\text { Line break (either poly break } \\
\text { or schedule- } 80 \text { steel break } \\
\text { inside or outside of } \\
\text { building). } \\
\text { Maintenance activity could } \\
\text { be the cause of failure. } \\
\text { especially poly. }\end{array}$} & $\begin{array}{l}\text { Loss of } \mathrm{Cl}_{2} \text { to water } \\
\text { treatment (see } \# 1-1) \text {. }\end{array}$ & & & $1-12$ & Low likelihood. \\
\hline & & & & $\begin{array}{l}\mathrm{Cl}_{2} \text { release (up to } 3 / 8 \text {-inch } \\
\text { release). } \\
\text { Potential for injuries and } \\
\text { fatalities near } 315 \text { Building } \\
\text { and neighboring buildings. }\end{array}$ & \multicolumn{2}{|c|}{$\begin{array}{l}\text { Regulator shuts off on loss } \\
\text { of vacuum. } \\
\text { Mitigation: } \mathrm{Cl}_{2} \text { alarm (local } \\
\text { and remote). Site-wide } \\
\text { emergency response lalarm } \\
\text { designed for leaks inside } \\
\text { building). "Chlorinator } \\
\text { trouble alarm" (315 } \\
\text { common alarm) with tour } \\
\text { operator response. }\end{array}$} & $1-13$ & $\begin{array}{l}\text { Low likelihood. Cause } \\
\text { and sufficient protection. } \\
\text { Verify that the adjacent } \\
\text { buildings have received } \\
\text { information on chlorine in } \\
\text { their HAZCOM program. }\end{array}$ \\
\hline
\end{tabular}




\begin{tabular}{|c|c|c|c|c|c|c|c|}
\hline \multicolumn{2}{|c|}{$\begin{array}{l}\text { PLANT/OPERATION: } \\
\text { LUENESSE NODE: } \\
\text { DESIGN ETTENTION: }\end{array}$} & \multicolumn{2}{|c|}{ 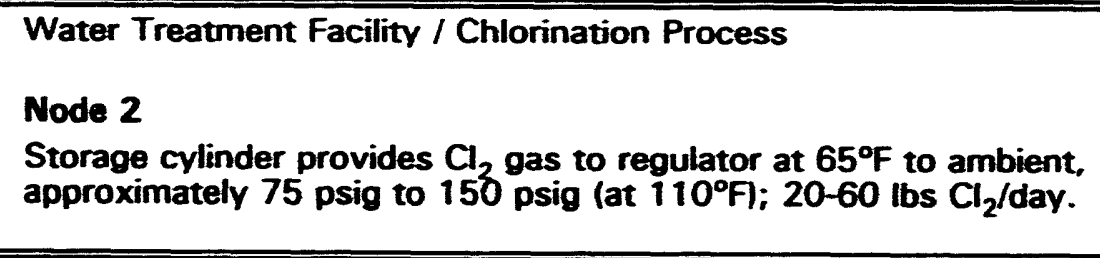 } & \multicolumn{4}{|c|}{$\begin{array}{l}\text { 5/19/93 } \\
\text { Chlorination Process Flow Diagram (Figure B-1) } \\
\text { F. Leverenz, S. Camp, J. Rude, K. Agee, } \\
\text { S. Kanth, K. Murphy, D. Ortiz, J. Angyus, } \\
\text { R. Hansen }\end{array}$} \\
\hline $\begin{array}{l}\text { GUIDE } \\
\text { WORD }\end{array}$ & DEVIATION & CAUSE & CONSEQUENCES & PRO & CTION & $\begin{array}{l}\text { SCE- } \\
\text { NARIO }\end{array}$ & ACTIONS/COMMENTS \\
\hline \multirow[t]{3}{*}{ No } & \multirow[t]{3}{*}{$\begin{array}{l}\mathrm{No} \mathrm{Cl}_{2} \\
\text { provided }\end{array}$} & Tank is empty. & Same as \#1-1. & \multicolumn{2}{|c|}{$\begin{array}{l}\text { Same as \#1-1 and weight } \\
\text { check. }\end{array}$} & $2-1$ & Same as \#1-1. \\
\hline & & \begin{tabular}{|l|} 
Tank valve is closed. \\
\end{tabular} & Same as \#1-1. & \multicolumn{2}{|c|}{ Same as $\$ 1-1$} & $2-2$ & Same as $\$ 1-1$ \\
\hline & & $\begin{array}{l}\text { Internal tank tubes are } \\
\text { plugged/defective } \\
\text { (blocked). }\end{array}$ & Same as \#1-1. & \multicolumn{2}{|c|}{ Same as $\$ 1-1$} & $2-3$ & Same as $\# 1-1$ \\
\hline More & $\begin{array}{l}\text { More } \mathrm{Cl}_{2} \\
\text { provided }\end{array}$ & No causes. & & & & & \\
\hline Less & $\begin{array}{l}\text { Less } \mathrm{Cl}_{2} \\
\text { provided }\end{array}$ & $\begin{array}{l}\text { Valve partially closed } \\
\text { I-HF: valve does not roedty indicate } \\
\text { mount open.l } \\
\text { Internal tank tubes partially } \\
\text { plugged. }\end{array}$ & $\begin{array}{l}\text { Same as } 2-2 \text { and } 2-3 \\
\text { except takes longer to } \\
\text { occur. }\end{array}$ & \multicolumn{2}{|c|}{ Same as $\$ 2-2$ and 2-3. } & $2-4$ & Same as $2-2$ and $2-3$. \\
\hline More & $\begin{array}{l}\text { High } \\
\text { temperature }\end{array}$ & $\begin{array}{l}\text { Heater fails "on" during } \\
\text { summer heat. }\end{array}$ & $\begin{array}{l}\text { If the temperature is greater } \\
\text { than } 160^{\circ} \mathrm{F} \text {, the fusible link } \\
\text { may release resulting in a } \\
\mathrm{Cl}_{2} \text { release. } \\
\text { Potential for injuries and } \\
\text { fatalities near the } 315 \\
\text { Building and neighboring } \\
\text { buildings. }\end{array}$ & \multicolumn{2}{|c|}{ 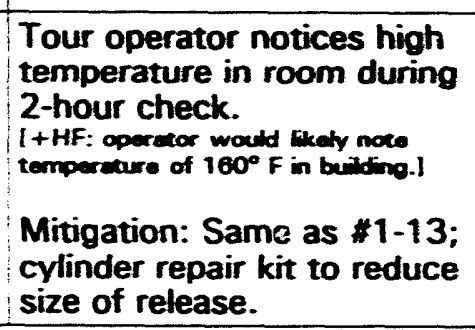 } & $2-5$ & $\begin{array}{l}\text { Calculate temperature } \\
\text { based on heat input } \\
\text { versus heat loss for this } \\
\text { scenario. Base further } \\
\text { recommendation items on } \\
\text { the results. }\end{array}$ \\
\hline
\end{tabular}




\begin{tabular}{|c|c|c|c|c|c|c|c|}
\hline $\begin{array}{l}\text { PLANT /OPERATION: } \\
\text { LINENESSEL/NODE: } \\
\text { DESION INTENTION: }\end{array}$ & \multicolumn{3}{|c|}{ 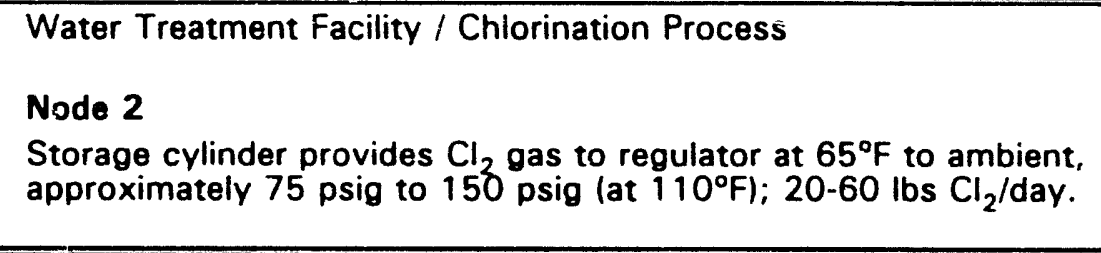 } & $\begin{array}{l}\text { REVIEW DATE: } \\
\text { DRAWING NO.: } \\
\text { REVIEW TEAM: }\end{array}$ & \multicolumn{3}{|c|}{$\begin{array}{l}5 / 19 / 93 \\
\text { Chlorination Process Flow Diagram (Figure B-1) } \\
\text { F. Leverenz, S. Camp, J. Rude, K. Agee, } \\
\text { S. Kanth, K. Murphy, D. Ortiz, J. Angyus, } \\
\text { R. Hansen }\end{array}$} \\
\hline $\begin{array}{l}\text { GUIDE } \\
\text { WORD }\end{array}$ & DEVIATION & CAUSE & CONSEQUENCES & PRO & CTION & $\begin{array}{l}\text { SCE- } \\
\text { NARIO }\end{array}$ & ACTIONS/COMMENTS \\
\hline $\begin{array}{l}\text { More } \\
\text { (cont.) }\end{array}$ & & $\begin{array}{l}\text { Fire } \\
\text { The following :educes the } \\
\text { likelihood of a fire: } \\
\text { - Internal fire: no } \\
\text { combustible or } \\
\text { flammable materials } \\
\text { are stored in the } \\
\text { building. } \\
\text { - External fire: there are } \\
\text { no likely fire sources. } \\
\text { Housekeeping } \\
\text { procedures are used to } \\
\text { prevent combustible or } \\
\text { flammable materials } \\
\text { from entering the } \\
\text { building. }\end{array}$ & $\begin{array}{l}\text { If fusible plug(s) work, } \\
\text { release will occur via plug. } \\
\text { If not, a BLEVE could result. } \\
\text { Same as } \# 2-5 \text {. }\end{array}$ & None. & & $2-6$ & Fire is very unlikely. \\
\hline Less & $\begin{array}{l}\text { Low } \\
\text { temperature }\end{array}$ & $\begin{array}{l}\text { Heater fails in the } \\
\text { winter/cold weather. }\end{array}$ & $\begin{array}{l}\text { Potential reduction in } \mathrm{Cl}_{2} \\
\text { feed rate; no significant } \\
\text { consequence. }\end{array}$ & & & $2-7$ & Minor consequences. \\
\hline More & High Pressure & $\begin{array}{l}\text { Cylinder is received } \\
\text { overfilled. }\end{array}$ & Unknown & $\begin{array}{l}\text { Check cyling } \\
\text { against the } \\
\text { properly fille } \\
\text { cylinder. } \\
\text { l-HF: procodure } \\
\text { "zero" woight fo } \\
\text { not notice overn }\end{array}$ & $\begin{array}{l}\text { weight } \\
\text { ight of a } \\
\text { chlorine } \\
\text { quires operator to } \\
\text { ow cylinder; may } \\
\text { ht.] }\end{array}$ & $2-8$ & $\begin{array}{l}\text { Check pressure potential } \\
\text { from chlorine cylinder and } \\
\text { the system (regulator) } \\
\text { response. Determine } \\
\text { whether the fusible plug } \\
\text { will open with high } \\
\text { pressure. }\end{array}$ \\
\hline Less & Low pressure & $\begin{array}{l}\text { Covered under low } \\
\text { temperature }(\# 2-7) \text {; no } \\
\text { additional causes related } \\
\text { to hazards. }\end{array}$ & & & & $2-9$ & \\
\hline $\begin{array}{l}\text { As well } \\
\text { as }\end{array}$ & $\begin{array}{l}\text { Other material } \\
\text { added }\end{array}$ & $\mathrm{Cl}_{2}$ contaminated. & Unknown & & & $2-10$ & $\begin{array}{l}\text { Check with vendor } \\
\text { regarding possible } \\
\text { contamination material for } \\
\text { scenarios } 2-10 \text { and } 2-11 \text {. } \\
\text { Take appropriate } \\
\text { recommendation/action. }\end{array}$ \\
\hline
\end{tabular}




\begin{tabular}{|c|c|c|c|c|c|c|c|c|}
\hline \multicolumn{2}{|c|}{$\begin{array}{l}\text { PLANT/OPERATION: } \\
\text { LINE/NESSEL/NODE: } \\
\text { DESIGN INTENTION: }\end{array}$} & \multicolumn{3}{|c|}{$\begin{array}{l}\text { Water Treatment Facility / Chlorination Process } \\
\text { Node } 2 \\
\text { Storage cylinder provides } \mathrm{Cl}_{2} \text { gas to regulator at } 65^{\circ} \mathrm{F} \text { to ambient, } \\
\text { approximately } 75 \text { psig to } 150 \text { psig (at } 110^{\circ} \mathrm{F} \text { ); } 20-60 \text { lbs } \mathrm{Cl}_{2}^{\prime} \text { 'day. }\end{array}$} & $\begin{array}{l}\text { REVIEW DATE: } \\
\text { DRAMNG NO.: } \\
\text { REVIEW TEAM: }\end{array}$ & \multicolumn{3}{|c|}{$\begin{array}{l}\text { Chlorination Process Flow Diagram (Figure B-1) } \\
\text { F. Leverenz, S. Camp, J. Rude, K. Agee, } \\
\text { S. Kanth, K. Murphy, D. Ortiz, J. Angyus, } \\
\text { R. Hansen }\end{array}$} \\
\hline $\begin{array}{l}\text { GUIDE } \\
\text { WORD }\end{array}$ & DE & IATION & CAUSE & CONSEQUENCES & PRO & CTION & $\begin{array}{c}\text { SCE- } \\
\text { NARIO }\end{array}$ & ACTIONS/COMMENTS \\
\hline $\begin{array}{l}\text { Other } \\
\text { than }\end{array}$ & $\begin{array}{l}\text { Anot } \\
\text { mate } \\
\text { loade }\end{array}$ & & $\begin{array}{l}\text { Cylinder contains } \\
\text { something other than } \\
\text { chlorine (e.g., sulfur } \\
\text { dioxide uses same size } \\
\text { container). }\end{array}$ & Unknown & & & $2-11$ & See above. \\
\hline Part of & $\begin{array}{l}\text { No } m \\
\text { devia }\end{array}$ & $\begin{array}{l}\text { aningful } \\
\text { ions }\end{array}$ & & & & & & \\
\hline
\end{tabular}

Hazard and Operability Study Worksheet 


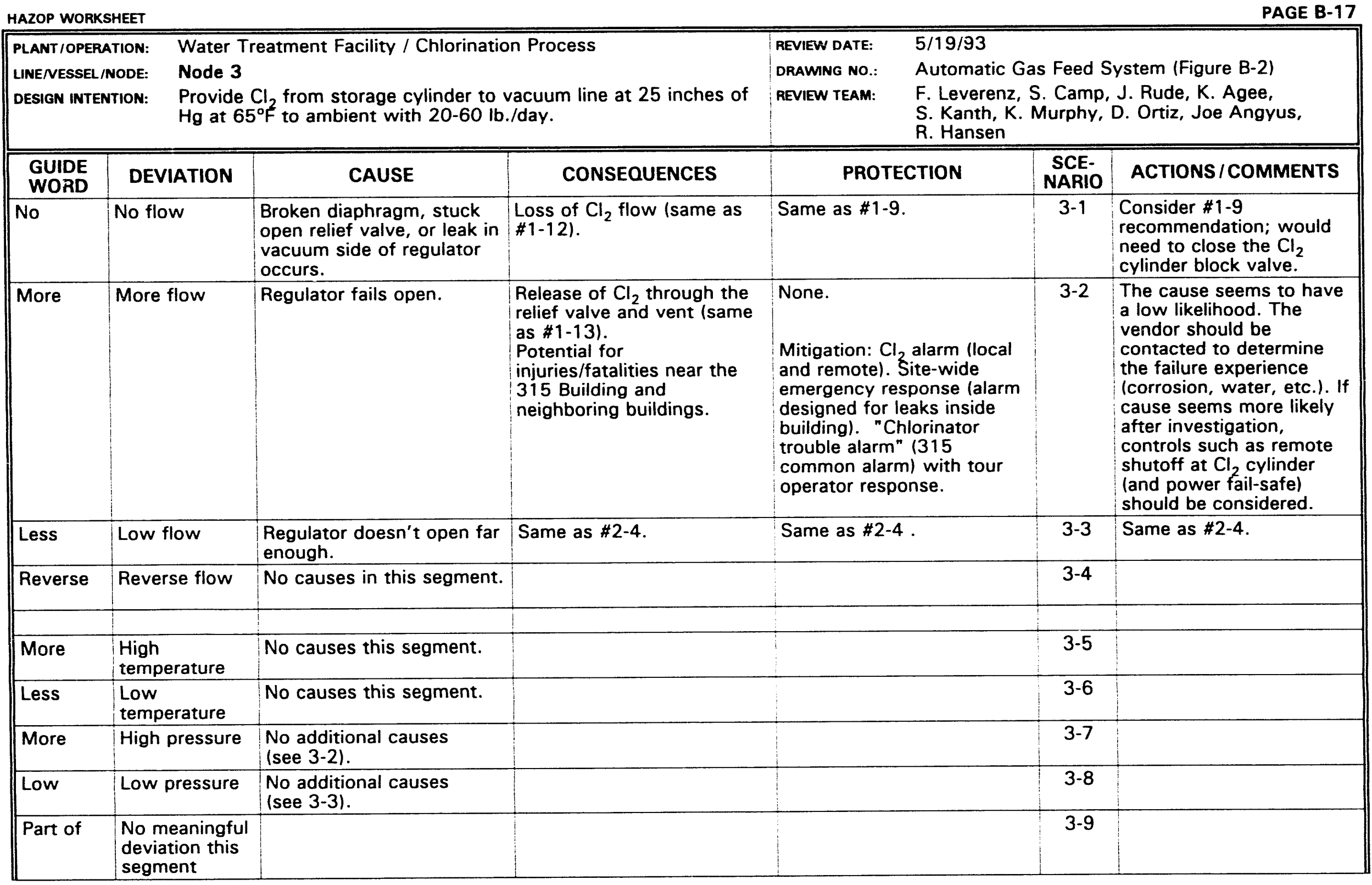




\begin{tabular}{|c|c|c|c|c|c|c|c|c|}
\hline \multicolumn{2}{|c|}{$\begin{array}{l}\text { PLANT/OPERATION: } \\
\text { LINENESSEL/NODE: } \\
\text { DESIGN INTENTION: }\end{array}$} & \multicolumn{3}{|c|}{$\begin{array}{l}\text { Water Treatment Facility / Chlorination Process } \\
\text { Node } 3 \\
\text { Provide } \mathrm{Cl}_{2} \text { from storage cylinder to vacuum line at } 25 \text { inches of } \\
\mathrm{Hg}=\mathrm{t} 65^{\circ} \mathrm{F} \text { to ambient with } 20-60 \mathrm{lb} \text {./day. }\end{array}$} & \multirow[t]{2}{*}{$\begin{array}{l}\text { REVIEW DATE: } \\
\text { DRAWNG NO.: } \\
\text { REVIEW TEAM: }\end{array}$} & \multicolumn{3}{|c|}{$\begin{array}{l}\text { 5/19/93 } \\
\text { Automatic Gas Feed System (Figure B-2) } \\
\text { F. Leverenz, S. Camp, J. Rude, K. Agee, } \\
\text { S. Kanth, K. Murphy, D. Ortiz, Joe Angyus, } \\
\text { R. Hansen }\end{array}$} \\
\hline $\begin{array}{l}\text { GUIDE } \\
\text { WORD }\end{array}$ & DEI & IATION & CAUSE & CONSEQUENCES & & CTION & $\begin{array}{c}\text { SCE- } \\
\text { NARIO }\end{array}$ & ACTIONS / COMMENTS \\
\hline $\begin{array}{l}\text { As well } \\
\text { as }\end{array}$ & $\begin{array}{l}\text { Mate } \\
\text { atmo } \\
\text { side } \\
\text { regul }\end{array}$ & $\begin{array}{l}\text { al in the } \\
\text { pheric } \\
\text { the } \\
\text { tor }\end{array}$ & $\begin{array}{l}\text { Sand, water, bugs, dust, } \\
\text { etc. }\end{array}$ & $\begin{array}{l}\text { Blocked vent line; if an } \\
\text { over-pressure event occurs } \\
\text { (3-2) the vacuum line could } \\
\text { become over-pressured; the } \\
\text { vacuum line may not hold } \\
\text { under pressure (same as } \\
\# 1-13) \text {. }\end{array}$ & $\begin{array}{l}\text { Vent screen } \\
\text { somewhat is }\end{array}$ & $\begin{array}{l}\text { ill protect } \\
\text { ne as } \# 1-13) \text {. }\end{array}$ & $3-10$ & $\begin{array}{l}\text { Verify that the screen is } \\
\text { in place. }\end{array}$ \\
\hline
\end{tabular}




\begin{tabular}{|c|c|c|c|c|c|c|c|}
\hline \multicolumn{2}{|c|}{$\begin{array}{l}\text { PLANT/OPERATION: } \\
\text { LINE/NESSEL/NODE: } \\
\text { DESIGN INTENTION: }\end{array}$} & \multicolumn{2}{|c|}{$\begin{array}{l}\text { Water Treatment Facility / Chlorination Process } \\
\text { Node } 4 \\
\text { Provide } \mathrm{Cl}_{2} \text { to ejector at } 25 \text { inches of } \mathrm{Hg} \text {, vacuum, } \\
20-60 \mathrm{lb} / \mathrm{day}, 65^{\circ} \mathrm{F} \text { to ambient }\end{array}$} & $\begin{array}{l}\text { REVIEW DATE: } \\
\text { DRAWNG NO.: } \\
\text { REVIEW TEAM: }\end{array}$ & \multicolumn{3}{|c|}{$\begin{array}{l}5 / 19 / 93 \\
\text { Automatic Gas Feed System and Chlorination } \\
\text { Process Flow Diagram (Figures B-1 and B-2) } \\
\text { F. Leverenz, S. Camp, J. Rude, K. Agee, } \\
\text { S. Kanth, K. Murphy, D. Ortiz, Joe Angyus, } \\
\text { R. Hansen }\end{array}$} \\
\hline $\begin{array}{l}\text { GUIDE } \\
\text { WORD } \\
\end{array}$ & DEVIATION & CAUSE & CONSEQUENCES & \multicolumn{2}{|c|}{ PROTECTION } & $\begin{array}{c}\text { SCE- } \\
\text { NARIO }\end{array}$ & ACTIONS/COMMENTS \\
\hline No & No flow & $\begin{array}{l}\text { Motor-controlled rate valve } \\
\text { closed. } \\
\text { - Failed closed. } \\
\text { - Operator closes rate } \\
\text { control valve } \\
\text { inadvertently. } \\
\text { I+HF: "up/down" key psd with } \\
\text { digital readout display of } \\
\text { position.] } \\
\text { Ejector check valve failed } \\
\text { closed. } \\
\text { Valves plugged by dirt. }\end{array}$ & Same as \#1-1. & Same as \#1- & & 4-1 & Protection sufficient. \\
\hline More & More flow & $\begin{array}{l}\text { Rotameter opened too far. } \\
\text { - Rate valve opened too } \\
\text { far. } \\
\text { [-HF: possible orror in residual } \\
\text { sample or calculation } \\
\text { [ +HF: "up/down" key pad } \\
\text { with digital readout display of } \\
\text { position.] } \\
\text { - Manual rate valve also } \\
\text { Opened. } \\
\text { [-HF: confusion of which } \\
\text { control to uso] } \\
\text { - Operator does not } \\
\text { reset to a lower value } \\
\text { when the demand } \\
\text { decreases. } \\
\text { I-HF: operators depend on } \\
\text { momory to complote actions.] } \\
\text { PLC controller fails. }\end{array}$ & $\begin{array}{l}\text { Objectionable tastes/vapors } \\
\text { in the water. }\end{array}$ & \multicolumn{2}{|c|}{$\begin{array}{l}\text { 1) Operator checks visual } \\
\text { flow on rotameter at } \\
\text { tank. } \\
\text { [-HF: operator usuelly rolies on } \\
\text { dioital is not likely used to using } \\
\text { rotameter flow indication.] } \\
\text { 2) Surveillance of } \\
\text { "residuals" (see } \\
\text { Protection 3) for \#1-1. }\end{array}$} & $4-2$ & Minor consequence. \\
\hline
\end{tabular}


HAZOP WORKSHEET

\begin{tabular}{|c|c|c|c|c|c|c|}
\hline \multicolumn{2}{|c|}{$\begin{array}{l}\text { PLANT/OPERATION: } \\
\text { UNE/NESSEL/NODE: } \\
\text { DESIGN INTENTION: }\end{array}$} & \multicolumn{2}{|c|}{$\begin{array}{l}\text { Water Treatment Facility / Chlorination Process } \\
\text { Node } 4 \\
\text { Provide } \mathrm{Cl}_{2} \text { to ejector at } 25 \text { inches of } \mathrm{Hg} \text {, vacuum, } \\
20-60 \mathrm{lb} / \mathrm{day}, 65^{\circ} \mathrm{F} \text { to ambient }\end{array}$} & \multirow[t]{2}{*}{$\begin{array}{l}\text { REVIEW DATE: } \\
\text { DRAWING NO.: } \\
\text { REVIEW TEAM: }\end{array}$} & \multicolumn{2}{|c|}{$\begin{array}{l}\text { 5/19/93 } \\
\text { Automatic Gas Feed System and Chlorination } \\
\text { Process Flow Diagram (Figures B-1 and B-2) } \\
\text { F. Leverenz, S. Camp, J. Rude, K. Agee, } \\
\text { S. Kanth, K. Murphy, D. Ortiz, Joe Angyus, } \\
\text { R. Hansen }\end{array}$} \\
\hline $\begin{array}{l}\text { GUIDE } \\
\text { WORD }\end{array}$ & DEVIATION & CAUSE & CONSEQUENCES & & $\begin{array}{l}\text { SCE- } \\
\text { NARIO }\end{array}$ & ACTIONS / COMMENTS \\
\hline Less & Less flow & $\begin{array}{l}\text { Plugged ejector. } \\
\text { Rotameter closed too } \\
\text { much. } \\
\text { - Rate valve not opened } \\
\text { enough. } \\
\text { I-HF: possiblo orror in rosidual } \\
\text { samplo or calculation } \\
\text { i +HF: -up/lown' koy pod } \\
\text { with digital roadout display of } \\
\text { positionl. } \\
\text { - Operator does not } \\
\text { reset to a higher value } \\
\text { when the demand } \\
\text { increases. } \\
\text { I-HF: oporators dopond on } \\
\text { momory to comploto actions.l } \\
\text { - PLC controller fails. }\end{array}$ & Same as \#1-3. & Same as \#1-3. & $4-3$ & Sufficient protection. \\
\hline More/less & $\begin{array}{l}\text { High or low } \\
\text { pressure }\end{array}$ & $\begin{array}{l}\text { Differential pressure } \\
\text { regulator. }\end{array}$ & Unknown & & $4-4$ & $\begin{array}{l}\text { How the differential } \\
\text { pressure regulator } \\
\text { operates is unknown. } \\
\text { The valve's operation } \\
\text { should be checked and } \\
\text { the potential for a } \\
\text { pressure deviation should } \\
\text { be assessed. }\end{array}$ \\
\hline
\end{tabular}




\begin{tabular}{|c|c|c|c|c|c|c|c|}
\hline \multicolumn{4}{|c|}{ HAZOP WORKSHEET } & & & & PAGE B-21 \\
\hline \multirow{2}{*}{$\begin{array}{l}\text { PLANT/OPERATION: } \\
\text { LINE/VESSEI/NODE: } \\
\text { DESIGN INTENTION: }\end{array}$} & \multirow{2}{*}{\multicolumn{3}{|c|}{$\begin{array}{l}\text { Water Treatment Facility / Chlorination Process } \\
\text { Node } 4 \\
\text { Provide } \mathrm{Cl}_{2} \text { to ejector at } 25 \text { inches of } \mathrm{Hg} \text {, vacuum, } \\
20-60 \mathrm{lb} / \text { day, } 65^{\circ} \mathrm{F} \text { to ambient }\end{array}$}} & \multirow{2}{*}{\multicolumn{4}{|c|}{ 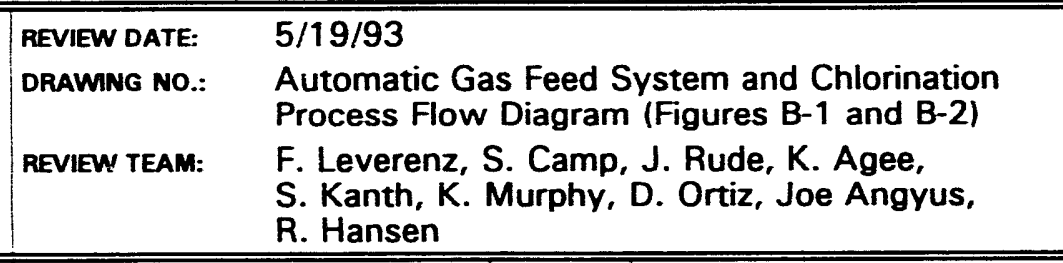 }} \\
\hline & & & & & & & \\
\hline $\begin{array}{l}\text { GUIDE } \\
\text { WORD }\end{array}$ & DEVIATION & CAUSE & CONSEQUENCES & PRO & CTION & $\begin{array}{c}\text { SCE- } \\
\text { NARIO }\end{array}$ & ACTIONS / COMMENTS \\
\hline \multirow[t]{2}{*}{ More } & \multirow[t]{2}{*}{$\begin{array}{l}\text { High } \\
\text { temperature }\end{array}$} & \multirow[t]{2}{*}{$\begin{array}{l}\text { Chlorinator heater fails } \\
\text { "on" in summer. }\end{array}$} & $\begin{array}{l}\text { Possible water pipe rupture } \\
\text { if the temperature exceeds } \\
\text { the PVC's strength. Small } \\
\text { chlorine release (no health } \\
\text { effects expected). }\end{array}$ & None. & & $4-5$ & Minor consequences. \\
\hline & & & $\begin{array}{l}\text { PLC operational limits. The } \\
\text { PLC could malfunction if } \\
\text { temperature is too high (see } \\
\text { less/more flow scenario, } \\
\# 1-2 \text { and } \# 1-3 \text { ). }\end{array}$ & Same as \#1 & and \#1-3. & $4-6$ & $\begin{array}{l}\text { (PLC operating range: } \\
\left.14^{\circ} \mathrm{F}-122^{\circ} \mathrm{F} .\right)^{-} \\
\text {Protection sufficient } \\
\text { (\#1-3) and minor } \\
\text { consequences }(\# 1-2) \text {. }\end{array}$ \\
\hline \multirow[t]{2}{*}{ Less } & \multirow[t]{2}{*}{$\begin{array}{l}\text { Low } \\
\text { temperature }\end{array}$} & \multirow[t]{2}{*}{$\begin{array}{l}\text { Heater fails during cold } \\
\text { weather (winter). }\end{array}$} & $\begin{array}{l}\text { Out-of-service water pipe } \\
\text { breaks (water freezes in the } \\
\text { line). }\end{array}$ & \multicolumn{2}{|c|}{$\begin{array}{l}\text { The operator's 2-hour check } \\
\text { of the facility. } \\
\text { 1-HF: operator may not note } \\
\text { cracked/broken line while it is still } \\
\text { frozen [ + HF: operator will likely note } \\
\text { temperature of building is low.] }\end{array}$} & $4-7$ & Minor consequences. \\
\hline & & & $\begin{array}{l}\text { Safety shower and eye } \\
\text { wash freezes. There is } \\
\text { potential for more serious } \\
\text { injury if an incident occurs } \\
\text { during unavailability. }\end{array}$ & \multicolumn{2}{|c|}{$\begin{array}{l}\text { Safety shower and eye } \\
\text { wash lines are heat traced. }\end{array}$} & $4-8$ & $\begin{array}{l}\text { Low likelihood that an } \\
\text { incident occurs the same } \\
\text { time freezing occurs. }\end{array}$ \\
\hline Part of & $\begin{array}{l}\text { No meaningful } \\
\text { deviation }\end{array}$ & & & & & & \\
\hline $\begin{array}{l}\text { As well } \\
\text { as }\end{array}$ & $\begin{array}{l}\text { Air into } \\
\text { chlorine } \\
\text { vacuum line }\end{array}$ & $\begin{array}{l}\text { Leak in the line/fittings: } \\
\text { potential for dissimilar } \\
\text { material to thermally } \\
\text { expand or contract from } \\
\text { temperature extremes. }\end{array}$ & Same as \#1-9 and \#1-10. & \multicolumn{2}{|c|}{$\begin{array}{l}\text { Operator check of chlorine } \\
\text { residuals. (Same as } \\
\text { Protection } 3 \text { of } \# 1-1 \text { ). }\end{array}$} & $4-9$ & Same as \#1-9 and \#1-10. \\
\hline Reverse & Reverse flow & Already covered \#1-4. & & & & 4-10 & Same as \#1-4. \\
\hline
\end{tabular}




\begin{tabular}{|c|c|c|c|c|c|c|}
\hline \multicolumn{2}{|c|}{$\begin{array}{l}\text { PLANT/OPERATION: } \\
\text { LNENESSEL/NODE: } \\
\text { DESIGN INTENTION: }\end{array}$} & \multicolumn{2}{|c|}{$\begin{array}{l}\text { Water Treatment Facility / Chlorination Process } \\
\text { Node } 4 \\
\text { Provide } \mathrm{Cl}_{2} \text { to ejector at } 25 \text { inches of } \mathrm{Hg} \text {, vacuum, } \\
20-60 \mathrm{lb} / \text { day, } 65^{\circ} \mathrm{F} \text { to ambient }\end{array}$} & \multicolumn{3}{|c|}{\begin{tabular}{|ll} 
REVIEW DATE: & $5 / 19 / 93$ \\
DRAWING No.: & Automatic Gas Feed System and Chlorination \\
& Process Flow Diagram (Figures B-1 and B-2) \\
REVIEW TEAM: & $\begin{array}{l}\text { F. Leverenz, S. Camp, J. Rude, K. Agee, } \\
\text { S. Kanth, K. Murphy, D. Ortiz, Joe Angyus, } \\
\text { R. Hansen }\end{array}$ \\
\end{tabular}} \\
\hline $\begin{array}{l}\text { GUIDE } \\
\text { WORD }\end{array}$ & DEVIATION & CAUSE & CONSEQUENCES & PROTECTION & $\begin{array}{c}\text { SCE- } \\
\text { NARIO }\end{array}$ & ACTIONS/COMMENTS \\
\hline $\begin{array}{l}\text { Other } \\
\text { than }\end{array}$ & $\begin{array}{l}\text { Air only into } \\
\text { injector }\end{array}$ & Line break in vacuum line. & Same as \#1-12. & Same as \#1-12. & 4-11 & Same as $\# 1-12$. \\
\hline None & No level & $\begin{array}{l}\text { Chlorine tank failure } \\
\text { (e.g., structural flaw). }\end{array}$ & $\begin{array}{l}\text { Release of contents. } \\
\text { Potential for injury and } \\
\text { fatalities of staff in the } \\
\text { surrounding area. }\end{array}$ & $\begin{array}{l}\text { None. } \\
\text { Mitigation: } \mathrm{Cl}_{2} \text { alarm (local } \\
\text { and remote). Site-wide } \\
\text { emergency response (alarm } \\
\text { designed for leaks inside } \\
\text { building). "Chlorinator } \\
\text { trouble alarm" ( } 315 \\
\text { common alarm) with tour } \\
\text { operator response. }\end{array}$ & 4-12 & Low likelihood. \\
\hline No & $\begin{array}{l}\text { Loss of utility } \\
\text { (off-site } \\
\text { power) }\end{array}$ & $\begin{array}{l}\text { Loss of electric power; } \\
\text { water pumps discontinue } \\
\text { operating. } \\
\text { (Loss of vacuum to } \\
\text { chlorinator). }\end{array}$ & $\begin{array}{l}\mathrm{Cl}_{2} \text { is release through the } \\
\text { vent. } \\
\mathrm{Cl}_{2} \text { contacts back flow } \\
\text { preventors with potential } \\
\text { damage to equipment. } \\
\\
\text { Up to } 3 / 8 \text {-inch leak with } \\
\text { potential for injuries and } \\
\text { fatalities near } 315 \text { Building } \\
\text { and neighboring buildings. }\end{array}$ & Regulator safety valve. & 4-13 & $\begin{array}{l}\text { Note: the detector has } \\
\text { battery backup and an } \\
\text { alarm on standby power. } \\
\text { Verify that the monthly } \\
\text { PM includes checking the } \\
\text { backup battery for the } \\
\text { chlorine alarm. } \\
\text { Note: there are plans to } \\
\text { put water pumps on } \\
\text { standby power, which } \\
\text { will make this "cause" } \\
\text { less likely. }\end{array}$ \\
\hline
\end{tabular}




\begin{tabular}{|c|c|c|c|c|c|c|c|}
\hline & & & & & & & PAGE B-2 \\
\hline $\begin{array}{l}\text { PLANT/OPE } \\
\text { LNENESSEI } \\
\text { DESIGN INTE } \\
\text { Guide WO }\end{array}$ & 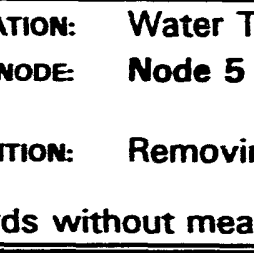 & $\begin{array}{l}\text { eatment Facility / Procedures } \\
\text { g Empty Chlorine Cylinder ( } w \\
\text { ingful deviations have been }\end{array}$ & $\begin{array}{l}\text { est cylinder) } \\
\text { mitted from this table. }\end{array}$ & $\begin{array}{l}\text { REVIEW DATE: } \\
\text { DRAMUNG NO.: } \\
\text { REVIEW TEAME: }\end{array}$ & $\begin{array}{l}\text { 5/20/93 } \\
\text { Procedures for } \\
\text { Cylinders (see } \\
\text { F. Leverenz, S. } \\
\text { S. Kanth, K. M } \\
\text { J. Piatt, R. Har }\end{array}$ & $\begin{array}{l}\text { the Cha } \\
\text { Appendi } \\
\text { Camp, } \\
\text { urphy, } \\
\text { isen }\end{array}$ & $\begin{array}{l}\text { nge-out of Chlorine } \\
\text { A) } \\
\text { Rude, K. Agee, } \\
\text { Ortiz, J. Angyus, }\end{array}$ \\
\hline $\begin{array}{l}\text { GUIDE } \\
\text { WORD }\end{array}$ & DEVIATION & CAUSE & CONSEQUENCES & PROT & ECTION & $\begin{array}{l}\text { SCE- } \\
\text { NARIO }\end{array}$ & ACTIONS/COMMENTS \\
\hline & (1) Notify the & 84 Powerhouse and the Han & ford Fire Department that the & chlorine cylin & er change-out i & in prog & ress. \\
\hline No & Skip step & Supervisor does not notify. & $\begin{array}{l}\text { May increase response } \\
\text { time/readiness of personnel } \\
\text { because of no advanced } \\
\text { warning. } \\
\text { False response upon } \\
\text { disconnect of regulator } \\
\text { resulting in } \mathrm{Cl}_{2} \text { alarm } \\
\text { (Step 11). }\end{array}$ & None. & & $5-1$ & Minor consequences. \\
\hline & (2) Start the 3 & $15 B$ Building vent fan and $O P$ & rate it for 3 minutes before & ntering. Main & ain the vent fan & continu & ously. \\
\hline No/less & $\begin{array}{l}\text { Skip step. } \\
\text { (Operate less } \\
\text { than } 3 \text { min.) }\end{array}$ & $\begin{array}{l}\text { The } \mathrm{Cl}_{2} \text { plant operator does } \\
\text { not start the fan. }\end{array}$ & $\begin{array}{l}\text { Possible exposure if a leak } \\
\text { exists and the detector } \\
\text { failed. } \\
\text { Possible irritation with low } \\
\text { likelihood of injury. }\end{array}$ & $\begin{array}{l}\text { Detector mah } \\
\text { alerts operatc } \\
\text { has failed. } \\
\text { - }-\mathrm{HF} \text { : oportarorm } \\
\text { asum no } \mathrm{Cl}_{2} \text { is }\end{array}$ & $\begin{array}{l}\text { unction alarm } \\
r \text { that detector } \\
\text { y procoed and } \\
\text { resent.l }\end{array}$ & $5-2$ & Low likelihood. \\
\hline & (3) Enter th & the walk-through door. & & & & & \\
\hline & $\begin{array}{l}\text { No meaningful } \\
\text { deviation }\end{array}$ & & & & & $5-3$ & \\
\hline
\end{tabular}




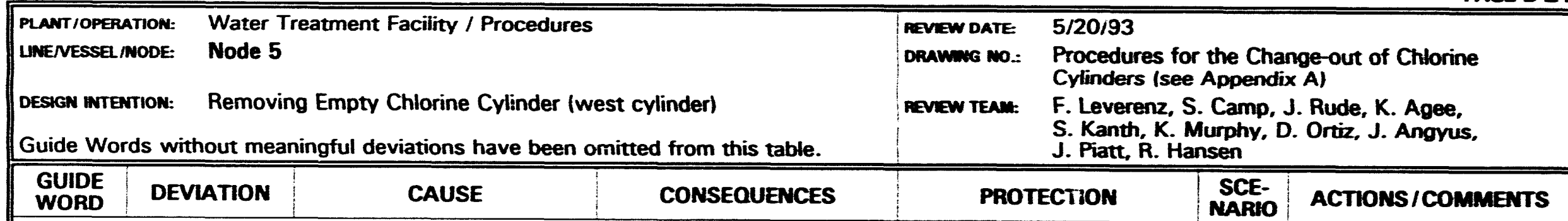

(4) Identify the empty cylinder by its weight, and verify the indication of no fiow on the cylinder regulator.

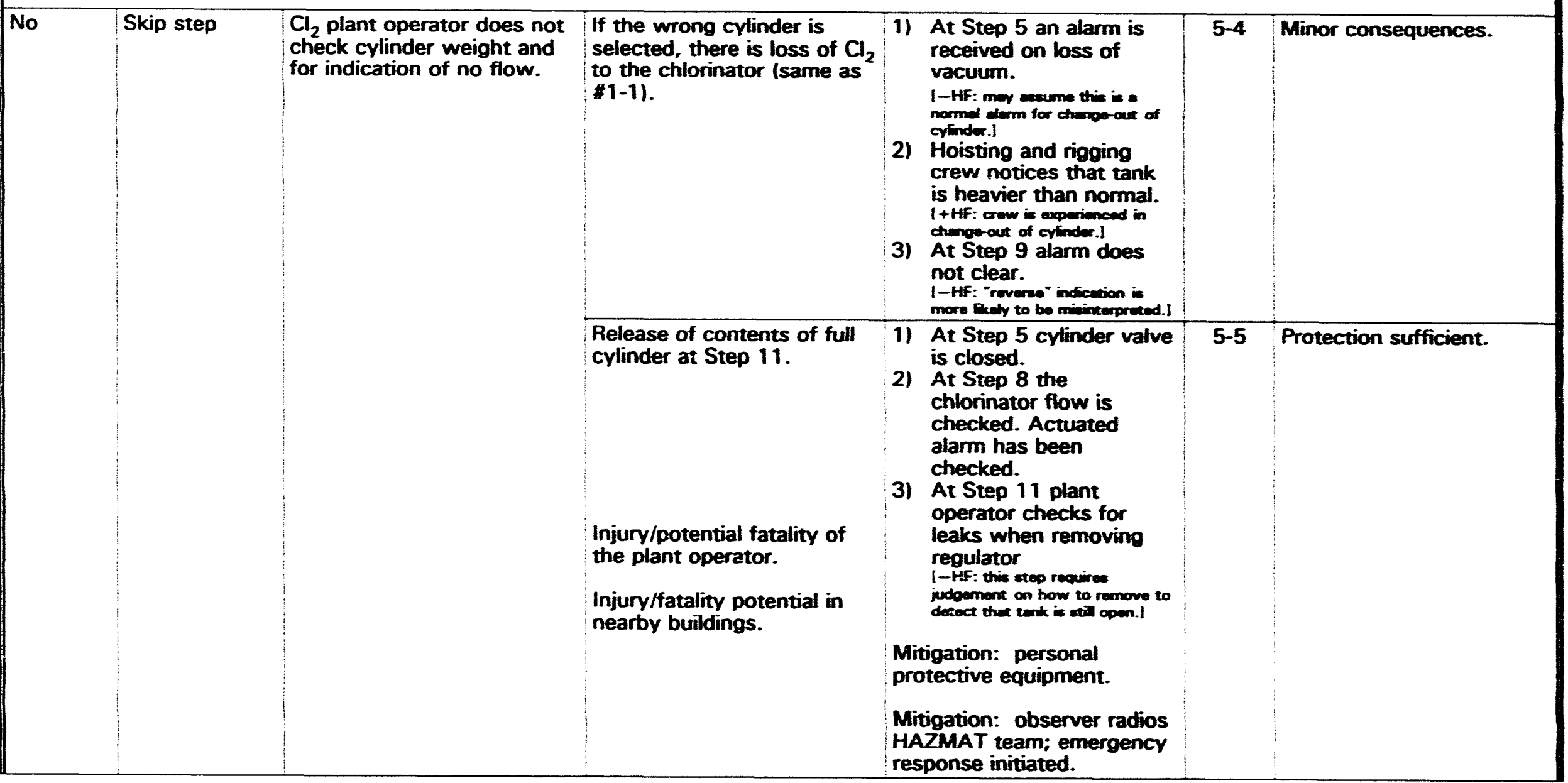




\begin{tabular}{|c|c|c|c|c|c|c|}
\hline \multicolumn{4}{|c|}{ 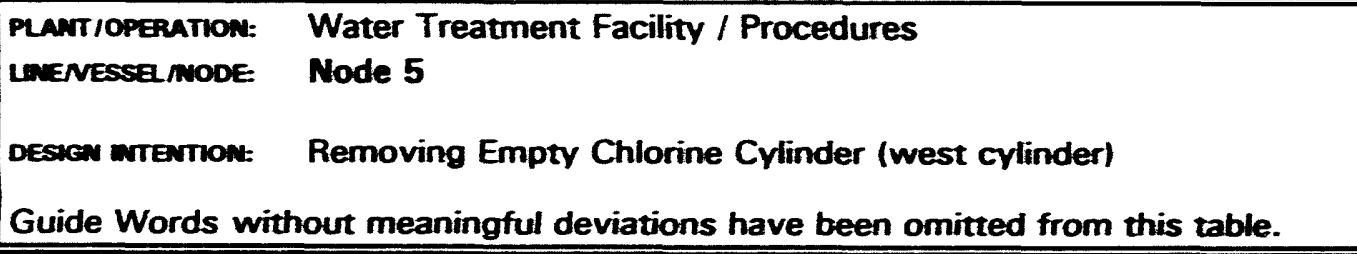 } & \multicolumn{3}{|c|}{ 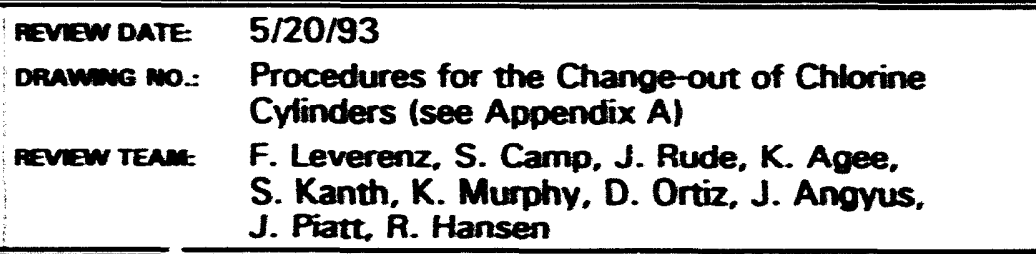 } \\
\hline $\begin{array}{l}\text { GUIDE } \\
\text { WORD }\end{array}$ & DEVIATION & CAUSE & CONSEQUENCES & PROTECTION & $\begin{array}{l}\text { SCE- } \\
\text { NARIO }\end{array}$ & ACTIONS/CONMENTS \\
\hline \multicolumn{7}{|c|}{ (5) Close the angle (root) valve on the chlorine cylinder. } \\
\hline No & Skip step & $\begin{array}{l}\mathrm{Cl}_{2} \text { plant operator does not } \\
\text { close the valve. }\end{array}$ & $\begin{array}{l}\text { Release of the remaining } \\
\text { Cylinder contents at } \\
\text { Step } 11 . \\
\text { Injury to plant operator. } \\
\text { Injury to staff in nearby } \\
\text { buildings. }\end{array}$ & $\begin{array}{l}\text { 1) Step } 8 \text { chlorinator flow } \\
\text { checked/alarm actuated. } \\
\text { 2) Step } 11 \text { slowhy } \\
\text { disconnect regulator } \\
\text { and check for leaks. } \\
\text { Mitigation: personnel } \\
\text { protective equipment. } \\
\text { Mitigation: observer radios } \\
\text { hazmat team; emergency } \\
\text { response initiated. }\end{array}$ & $5-6$ & Sufficient protection. \\
\hline Less & $\begin{array}{l}\text { Valve partially } \\
\text { closed. }\end{array}$ & $\begin{array}{l}\text { Plant operator does not } \\
\text { close the valve completely. } \\
\text { I-HF: valve provides no indicution of } \\
\text { position. I }\end{array}$ & $\begin{array}{l}\text { Lesser consequence than } \\
\$ 5-6 \text {. } \\
\text { Injury to plant operator. }\end{array}$ & $\begin{array}{l}\text { At Step } 11 \text { check for leaks } \\
\text { at disconnect. } \\
\text { 1-HF: } \\
\text { Mitigation: Personal } \\
\text { protection equipment. }\end{array}$ & $5-7$ & Sufficient protection. \\
\hline Reverse & $\begin{array}{l}\text { Valve opened } \\
\text { all the way }\end{array}$ & 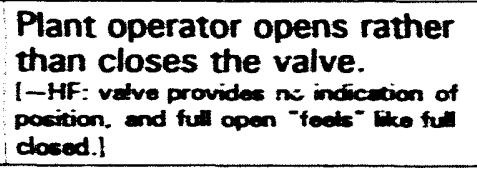 & Same as $\$ 5-6$. & Same as $\# 5-6$ & $5-8$ & Sufficient protection. \\
\hline & (6) Isolate th & automatic switch-over valve. & IClose valves G5, G6. an & & & \\
\hline No & Skip step & Plant operator skips step. & $\begin{array}{l}\text { At Step } 11 \text { when } \\
\text { disconnect slightty larger } \\
\text { release of } \mathrm{Cl}_{2} \text { - } \\
\text { Minor irritation. }\end{array}$ & $\begin{array}{l}\text { At Step 8, flow/vacuum } \\
\text { alarm check. }\end{array}$ & $5-9$ & Sufficient protection. \\
\hline
\end{tabular}




\begin{tabular}{|c|c|c|c|c|c|c|c|}
\hline \multicolumn{4}{|c|}{ 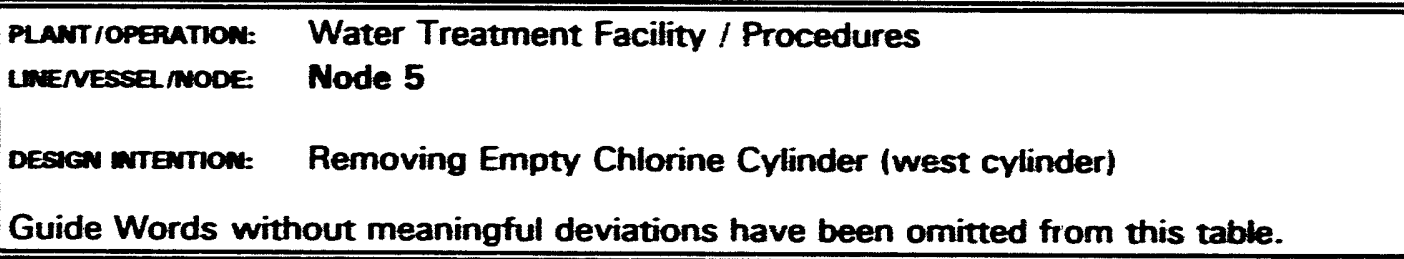 } & $\begin{array}{l}\text { REVEW DATE } \\
\text { DRAMUG MO.: } \\
\text { REVEW TEAM: }\end{array}$ & \multicolumn{3}{|c|}{$\begin{array}{l}\text { 5/20/93 } \\
\text { Procedures for the Change-out of Chlorine } \\
\text { Cylinders (see Appendix A) } \\
\text { F. Leverenz, S. Camp, J. Rude, K. Agee, } \\
\text { S. Kanth, K. Murphy, D. Ortiz, J. Angyus, } \\
\text { J. Piatt, R. Hansen }\end{array}$} \\
\hline \multirow[t]{2}{*}{$\begin{array}{l}\text { GUIDE } \\
\text { WORD }\end{array}$} & DEVIATION & CAUSE & CONSEQUENCES & \multicolumn{2}{|c|}{ PROTECTION } & $\begin{array}{l}\text { SCE- } \\
\text { NARIO }\end{array}$ & ACTIONS/COMBAENTS \\
\hline & \multicolumn{3}{|c|}{ (7) Verify that valves $G 8$ and $G 4$ are closed. } & & & & \\
\hline \multirow[t]{2}{*}{ No } & Skip step & $\begin{array}{l}\text { Plant operator skips this } \\
\text { step. }\end{array}$ & No consequences. & & & $5-10$ & No consequences. \\
\hline & \multicolumn{7}{|c|}{$\begin{array}{l}\text { (8) Verify that valve G1 is open, and open valve G3. Wait } 2 \text { minutes and verify that there is no flow at the chlorinator in service. } \\
\text { Verify that the high-vacuum alarm is actuated. }\end{array}$} \\
\hline No & Skips step & $\begin{array}{l}\text { Plant operator skips this } \\
\text { step. }\end{array}$ & Same as $\# 5-9$. & $\begin{array}{l}\text { 1) Slow dis } \\
\text { leak chec } \\
\text { I-HF: soe } \\
\text { Mitigation: } \\
\text { protective eq }\end{array}$ & $\begin{array}{l}\text { Slow disconnect and } \\
\text { leak check at Step } 11 . \\
\text { [-HF: soe } 25-5.31 .1\end{array}$ & 5-11 & Sufficient protection. \\
\hline Less & Less time & $\begin{array}{l}\text { Plant operator proceeds } \\
\text { without waiting } 2 \mathrm{~min} \text {. }\end{array}$ & $\begin{array}{l}\text { Lesser consequence than } \\
\# 5-11 \text {. }\end{array}$ & \multicolumn{2}{|c|}{$\begin{array}{l}\text { Flow check at } \\
\text { chlorinator. } \\
\text { High vacuum alarm at } \\
\text { Step } 11 . \\
\text { Slow disconnect and } \\
\text { leak check at Step } 11 . \\
\text { !-HF: soo } \$ 5-5.31 .1\end{array}$} & 5-12 & Sufficient protection. \\
\hline \multirow[t]{2}{*}{ Part of } & $\begin{array}{l}\text { Skips check on } \\
\text { step }\end{array}$ & $\begin{array}{l}\text { Plant operator skips } \\
\text { "checks" of vacuum alarm } \\
\text { and flow. }\end{array}$ & $\begin{array}{l}\text { Loss of protection for this } \\
\text { step and for previous steps. }\end{array}$ & \multicolumn{2}{|c|}{ None. } & $5-13$ & No direct consequence. \\
\hline & Skips opening & $\begin{array}{l}\text { Plant operator does not } \\
\text { open G3. }\end{array}$ & Same as \#5-11. & \multicolumn{2}{|c|}{ Same as \#5-12. } & 5-14 & Sufficient protection. \\
\hline
\end{tabular}




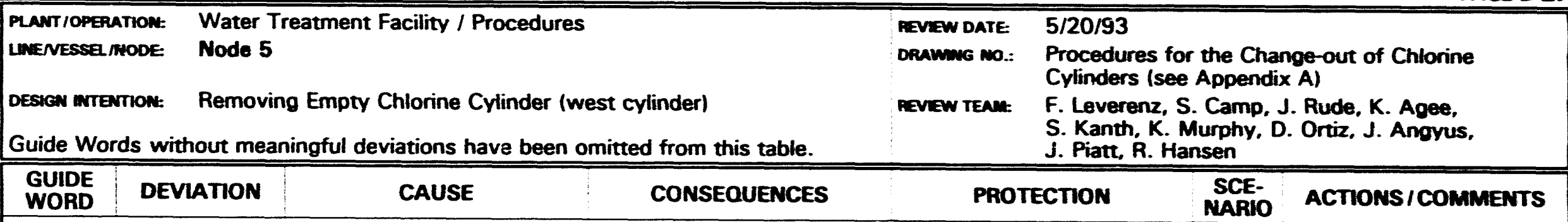

(9) Close valves G1 and G3. Open valves G6 and G9, and verify that the high-vacuum alarm clears.

\begin{tabular}{|c|c|c|c|c|c|c|}
\hline No & Skips step. & $\begin{array}{l}\text { Plant operator skips this } \\
\text { step. }\end{array}$ & $\begin{array}{l}\text { Same as \#1-12 when line } \\
\text { opened at Step } 11 .\end{array}$ & $\begin{array}{l}\text { Low vacuum alarm occurs } \\
\text { at Step } 11 .\end{array}$ & $5-15$ & Minor consequence. \\
\hline \multirow[t]{2}{*}{ Part of } & $\begin{array}{l}\text { Skips closing } \\
\text { valves. }\end{array}$ & $\begin{array}{l}\text { Plant operator does not } \\
\text { close G1 and G3. } \\
\text { [-HF: valves dose tooether and } \\
\text { oesy to confuse.] }\end{array}$ & $\begin{array}{l}\text { At Step } 11 \text { air is introduced } \\
\text { into the system, reducing } \\
\text { chlorination. }\end{array}$ & $\begin{array}{l}\text { Low vacuum alarm occurs } \\
\text { at Step } 11 .\end{array}$ & $5-16$ & Minor consequence. \\
\hline & $\begin{array}{l}\text { Skips opening } \\
\text { valves. }\end{array}$ & $\begin{array}{l}\text { Plant operator does not } \\
\text { open G6 and G9. } \\
\text { I-HF: }\end{array}$ & Same as $\# 1-1$ & $\begin{array}{l}\text { 1) High vacuum alarm } \\
\text { does not clear. } \\
\text { 2) } \mathrm{Cl}_{2} \text { residual checks (see } \\
\# 1-1 \text {, Protection 3). } \\
\end{array}$ & $5-17$ & Protection sufficient. \\
\hline \multirow[t]{2}{*}{$\begin{array}{l}\text { Other } \\
\text { than }\end{array}$} & $\begin{array}{l}\text { Wrong valves } \\
\text { are opened. }\end{array}$ & $\begin{array}{l}\text { Plant operator opens G5 } \\
\text { and G9. } \\
\text { I-HF: }=\text { * } 45-16.1\end{array}$ & Same as $\$ 5-15$. & Same as $\# 5-15$. & 5-18 & Minor consequence. \\
\hline & \multicolumn{2}{|l|}{$(10)$} & $\begin{array}{l}\text { ask respirator, and operator do } \\
\text { onal protective equipment. }\end{array}$ & ons self-contained breathing & aratus & (SCBA). Then \\
\hline No & Skip step & $\begin{array}{l}\text { Neglect to wear the } \\
\text { personal protective } \\
\text { equipment. }\end{array}$ & $\begin{array}{l}\text { Loss of protection for } \\
\text { scenarios where needed. }\end{array}$ & $\begin{array}{l}\text { Observer reminds } \\
\text { serviceman of need for } \\
\text { personal protective } \\
\text { equipment. }\end{array}$ & $5-20$ & No direct consequence. \\
\hline
\end{tabular}




\section{PLANT/OPERATION: Water Treatment Facility / Procedures \\ UNENESSEL MODE \\ Node 5}

DESIGN WTENTION:

Removing Empty Chlorine Cylinder (west cylinder)

Guide Words without meaningful deviations have been omitted from this table.
REVIEW DATE:

Procedures for the Change-out of Chlorine

Cylinders (see Appendix A)

revizw team: F. Leverenz, S. Camp, J. Rude, K. Agee,

S. Kanth, K. Murphy, D. Ortiz, J. Angyus, J. Piatt, R. Hansen

\begin{tabular}{|c|c|c|c|c|c|c|}
\hline $\begin{array}{l}\text { GUIDE } \\
\text { WORD }\end{array}$ & DEVIATION & CAUSE & CONSEQUENCES & PROTECTION & $\begin{array}{l}\text { SCE- } \\
\text { NARIO }\end{array}$ & ACTIONS/COMMENTS \\
\hline
\end{tabular}

(11) Slowly disconnect the regulator, check it for leaks, and set it on the floor.

\begin{tabular}{|c|c|c|c|c|c|c|c|}
\hline No & Skip step & $\begin{array}{l}\text { Serviceman does not } \\
\text { disconnect the regulator. }\end{array}$ & $\begin{array}{l}\text { Hoses could be broken if } \\
\text { cylinder is moved at } \\
\text { Step } 13 . \\
\text { Small release; minor } \\
\text { irritation. }\end{array}$ & \multicolumn{2}{|c|}{$\begin{array}{l}\text { Observation that regulator } \\
\text { is still connected. }\end{array}$} & $5-21$ & Minor consequences. \\
\hline Part of & $\begin{array}{l}\text { Skip part of } \\
\text { step. }\end{array}$ & 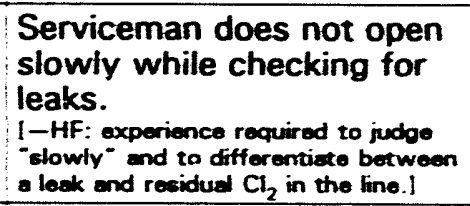 & $\begin{array}{l}\text { Loss of protection in } \\
\text { previous scenarios. }\end{array}$ & \multicolumn{2}{|c|}{ None. } & $5-22$ & No direct consequence. \\
\hline $\begin{array}{l}\text { As well } \\
\text { as }\end{array}$ & $\begin{array}{l}\text { Unwanted } \\
\text { action }\end{array}$ & $\begin{array}{l}\text { Serviceman drops regulator } \\
\text { after disconnect. }\end{array}$ & $\begin{array}{l}\text { Damage regulator; possible } \\
\text { "cause" for scenario in re- } \\
\text { connection. }\end{array}$ & \multicolumn{2}{|c|}{$\begin{array}{l}\text { Serviceman alerts } \\
\text { operations supervisor of } \\
\text { drop. }\end{array}$} & $5-23$ & No direct constquence. \\
\hline $\begin{array}{l}\text { Other } \\
\text { than }\end{array}$ & Wrong cylinder & $\begin{array}{l}\text { Serviceman selects the } \\
\text { wrong cylinder. }\end{array}$ & $\begin{array}{l}\text { Serviceman disconnects in- } \\
\text { use cylinder with release of } \\
\text { full cylinder contents (see } \\
5-5 \text { ). } \\
\text { Potential for injuries and } \\
\text { fatalities near } 315 \text { Building } \\
\text { and neighboring buildings. }\end{array}$ & 1) & 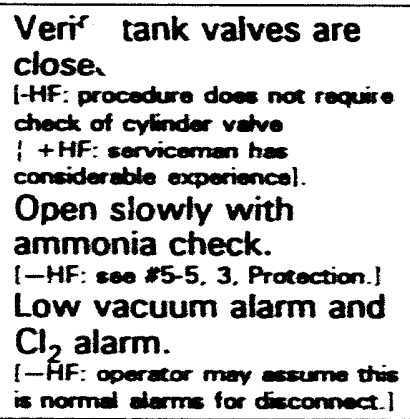 & $5-24$ & $\begin{array}{l}\text { Sufficient protection. } \\
\text { Existing tagging system to } \\
\text { be incorporated into } \\
\text { disconnect procedures. }\end{array}$ \\
\hline
\end{tabular}




\begin{tabular}{|c|c|c|c|}
\hline $\begin{array}{l}\text { PLANT/OPERATION: } \\
\text { LINENESSEL/NODE: }\end{array}$ & $\begin{array}{l}\text { Water Treatment Facility / Procedures } \\
\text { Node } 5\end{array}$ & $\begin{array}{l}\text { REVIEW DATE: } \\
\text { DRAWING NO.: }\end{array}$ & $\begin{array}{l}5 / 20 / 93 \\
\text { Procedures for the Change-out of Chlorine } \\
\text { Cylinders (see Appendix A) }\end{array}$ \\
\hline $\begin{array}{l}\text { DESIGN INTENTION: } \\
\text { Guide WordS W }\end{array}$ & $\begin{array}{l}\text { Removing Empty Chlorine Cylinder (west cylinder) } \\
\text { out meaningful deviations have been omitted from this table. }\end{array}$ & REVIEW TEAM: & $\begin{array}{l}\text { F. Leverenz, S. Camp, J. Rude, K. Agee, } \\
\text { S. Kanth, K. Murphy, D. Ortız, J. Angyus, } \\
\text { J. Piatt, R. Hansen }\end{array}$ \\
\hline
\end{tabular}

Guide Words without meaningful deviations have been omitted from this table. J. Piatt, R. Hansen

\begin{tabular}{|c|c|c|c|c|c|c|}
\hline $\begin{array}{l}\text { GUIDE } \\
\text { WORD }\end{array}$ & DEVIATION & CAUSE & CONSEQUENCES & PROTECTION & $\begin{array}{c}\text { SCE- } \\
\text { NARIO }\end{array}$ & ACTIONS / COMMENTS \\
\hline
\end{tabular}

(12) Install the cap on the cylinder angle valve, and install the protective hood.

\begin{tabular}{|l|l|l|l|l|l|}
\hline No & Skip step & $\begin{array}{l}\text { Serviceman does not install } \\
\text { the cap. }\end{array}$ & $\begin{array}{l}\text { Loss of protection for } \\
\text { valves and threads during } \\
\text { subsequent handling } \\
\text { incidents. }\end{array}$ & $\begin{array}{l}\text { Visual observation when } \\
\text { cylinder is moved (Step 13). }\end{array}$ & \begin{tabular}{l}
$5-25$ \\
\hline
\end{tabular} \\
\hline
\end{tabular}

(13) Position the crane and cylinder truck for loading; open the roll-up door; remove the chocks; and push the cylinder out to the stops.

\begin{tabular}{|c|c|c|c|c|c|c|}
\hline Reverse & $\begin{array}{l}\text { Reverse part } \\
\text { of step }\end{array}$ & $\begin{array}{l}\text { Trucks are not in place } \\
\text { when cylinder rolled out. }\end{array}$ & $\begin{array}{l}\text { Possibility of vehicle } \\
\text { impact with the cylinder } \\
\text { resulting in release of } \mathrm{Cl}_{2} \text {. } \\
\text { Potential injuries in the } \\
\text { area. }\end{array}$ & None. & $5-26$ & Low likelihood. \\
\hline
\end{tabular}

(14) Release the chain binders, and turn the cylinder over to the hoist and rigging crew.

\begin{tabular}{|c|c|c|c|c|c|c|}
\hline No & Skip step & $\begin{array}{l}\text { Chain binders are not } \\
\text { released. }\end{array}$ & $\begin{array}{l}\text { Cannot load cylinder onto } \\
\text { the truck; potential damage } \\
\text { to the equipment. }\end{array}$ & $\begin{array}{l}\text { Hoist crew notes that the } \\
\text { chain is connected. }\end{array}$ & $5-27$ & Minor consequence. \\
\hline \multicolumn{6}{|c|}{ (15) } & $\begin{array}{l}\text { Note: hoisting and rigging } \\
\text { crew has detailed } \\
\text { procedure. }\end{array}$ \\
\hline Part of & $\begin{array}{l}\text { Incomplete } \\
\text { installation }\end{array}$ & Partially hooked. & $\begin{array}{l}\text { The dropped cylinder is } \\
\text { damaged resulting in a } \mathrm{Cl}_{2} \\
\text { release. } \\
\text { Same as } \# 5-26 \text {. }\end{array}$ & Radio for hazmat support. & $5-28$ & Low likelihood. \\
\hline $\begin{array}{l}\text { As well } \\
\text { as }\end{array}$ & $\begin{array}{l}\text { Unwanted } \\
\text { action }\end{array}$ & $\begin{array}{l}\text { Crane operator mishandles } \\
\text { the cylinder lift. }\end{array}$ & $\begin{array}{l}\text { Cylinder strikes object. } \\
\text { Same as } \# 5-28 \text {. }\end{array}$ & None. & $5-29$ & Low likelihood. \\
\hline Part of & Fails during lift & $\begin{array}{l}\text { Crane or rigging fails } \\
\text { (broken cables, etc.). }\end{array}$ & Same as $\# 5-28$. & Same as $\# 5-28$. & $5-30$ & $\begin{array}{l}\text { Low likelihood. Rigging is } \\
\text { certified by non- } \\
\text { destructive examination. }\end{array}$ \\
\hline
\end{tabular}




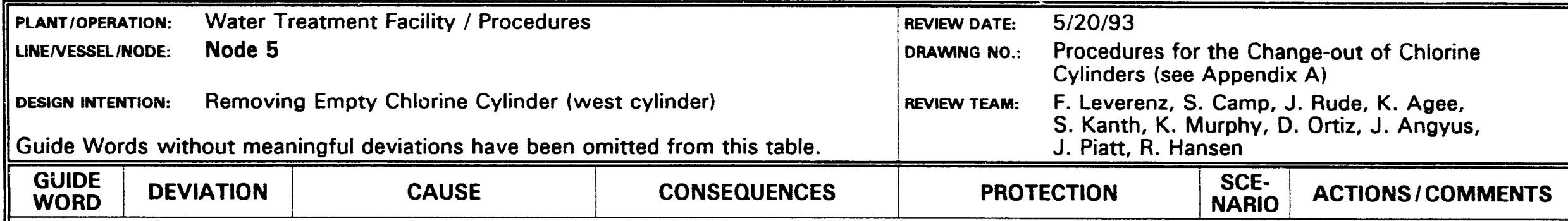

(16) Secure the cylinder and transport it.

\begin{tabular}{|c|c|c|c|c|c|c|}
\hline No & Skip step & $\begin{array}{l}\text { Driver does not secure the } \\
\text { cylinder. }\end{array}$ & $\begin{array}{l}\text { The cylinder is released } \\
\text { during transport (e.g., falls } \\
\text { off truck). Potential for } \\
\text { cylinder failure, } \mathrm{Cl}_{2} \text { release } \\
\text { and injuries to people along } \\
\text { the route. }\end{array}$ & None. & $5-31$ & Low !ikelihood. \\
\hline \multicolumn{7}{|c|}{ (17) Close the roll-up door, and exit through the walk-through door. } \\
\hline No & Skip step & $\begin{array}{l}\text { Plant operator does not } \\
\text { close the doors. }\end{array}$ & $\begin{array}{l}\text { May compromise } \\
\text { effectiveness of } \mathrm{Cl}_{2} \\
\text { detectors. }\end{array}$ & Tour operator surveillance. & $5-32$ & Low likelihood. \\
\hline
\end{tabular}

Hazard and Operability Study Worksheot 


\section{PLANT/OPERATION: \\ LNENESSEL/NODE \\ Water Treatment Facility / Procedures \\ Node 6}

DESIGN INTENTION: Install Replacement Chlorine Cylinder (west cylinder)

Guide Words without meaningful deviations have been omitted from this table.

\begin{tabular}{|l|l|l|l}
\hline GUIDE & DEVIATION & CAUSE & CONSEQUENCES \\
\hline
\end{tabular}

DEVIATION

CAUSE

CONSEQUENCES

\section{REVIEW DATE: $5 / 21 / 93$}

DRAMng no: Procedures for the Change-out of Chlorine

Cylinders (see Appendix A)

REVIEW TEAM: F. Leverenz, J. Rude, S. Camp, D. Ortiz,

J. Angyus, R. Hansen

(1) Turn on or verify that the storage room exhaust fan is on.

\begin{tabular}{||l|l|l|}
\hline No & Skip step & $\begin{array}{l}\text { Plant operator does not turn } \\
\text { the fan on. }\end{array}$ \\
& & \\
\hline
\end{tabular}

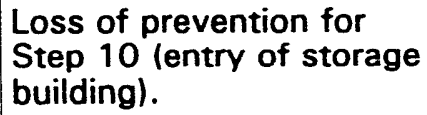

oss of prevention for Step 10 (entry of storage building). off before entry and turns it on.

I-HF: serviceman works on many different installations and may not think to check the fan.

(2) Position the crane for unloading.

\begin{tabular}{|l|l|l|}
\hline Part of & $\begin{array}{l}\text { Mis- } \\
\text { positioned }\end{array}$ & $\begin{array}{l}\text { Crane is mis-positioned } \\
\text { (would require extreme mis- } \\
\text { positioning). }\end{array}$ \\
\end{tabular}

Difficulty in moving cylinder Other crew members.

to trolley; may delay

replacement. It is possible

that the cylinder could be

damaged.

Possible injuries and

fatalities in area if release

occurs from damage.

(3) Position the chlorine transport truck for unloading.

\begin{tabular}{|c|c|c|c|c|c|c|}
\hline Part of & Mis-positioned & $\begin{array}{l}\text { Truck is mis-positioned } \\
\text { (would require extreme mis- } \\
\text { positioning). }\end{array}$ & Same as \#6-2. & Same as \#6-2. & $6-3$ & Low likelihood. \\
\hline
\end{tabular}




\begin{tabular}{|c|c|c|c|c|c|c|c|}
\hline \multicolumn{2}{|c|}{$\begin{array}{l}\text { PLANT /OPERATION: } \\
\text { LINE/NESSEL/NODE: } \\
\text { DESIGN INTENTION: }\end{array}$} & $\begin{array}{l}\text { Water } \\
\text { Node } 6 \\
\text { Instail } \\
\text { lout me }\end{array}$ & $\begin{array}{l}\text { acility / P } \\
\text { Chlorine } \\
\text { iations he }\end{array}$ & $\begin{array}{l}\text { REVIEW DATE: } \\
\text { DRAMING NO.: } \\
\text { REVIEW TEAM: }\end{array}$ & $\begin{array}{l}5 / 21 / 9 \\
\text { Proced } \\
\text { Cylinde } \\
\text { F. Leve } \\
\text { J. Angy }\end{array}$ & $\begin{array}{l}\text { the Cha } \\
\text { Appendi } \\
\text { Rude, S } \\
\text { tansen }\end{array}$ & $\begin{array}{l}\text { ge-out of Chlorine } \\
\text { A) } \\
\text { Camp, D. Ortiz, }\end{array}$ \\
\hline $\begin{array}{l}\text { GUIDE } \\
\text { WORD }\end{array}$ & DE & ATION & CAUSE & \multicolumn{2}{|c|}{ PROTECTION } & $\begin{array}{c}\text { SCE- } \\
\text { NARIO }\end{array}$ & ACTIONS / COM \\
\hline
\end{tabular}

(4) Verify that the chlorine cylinder trolley is in position to receive the cylinder.

\begin{tabular}{|c|c|c|c|c|c|c|}
\hline Part of & Mis-positioned & $\begin{array}{l}\text { Trolley is mis-positioned } \\
\text { and no correction occurs. } \\
\text { (The worst case is when } \\
\text { the trolley is off the track.) }\end{array}$ & $\begin{array}{l}\text { Same as } \# 6-2 \text {. } \\
\text { If it is off the track, it could } \\
\text { roll. (The apron or concrete } \\
\text { pad is sloped toward } \\
\text { parking lot.) It would likely } \\
\text { stop when the wheels run } \\
\text { off the apron onto the } \\
\text { gravel. }\end{array}$ & Same as \#6-2. & $6-4$ & Low likelihood. \\
\hline
\end{tabular}

(5) Release the cylinder binder(s) on the transport vehicle.

\begin{tabular}{|c|c|c|c|c|c|c|}
\hline No & Skip step & $\begin{array}{l}\text { Driver does not release the } \\
\text { binders. }\end{array}$ & $\begin{array}{l}\text { Cannot remove the } \\
\text { cylinder. }\end{array}$ & $\begin{array}{l}\text { Hoist and rigging crew } \\
\text { notice binder at Step } 6 .\end{array}$ & $6-5$ & Minor consequence. \\
\hline Part of & $\begin{array}{l}\text { Only one } \\
\text { binder in place }\end{array}$ & $\begin{array}{l}\text { Driver only releases one } \\
\text { binder. }\end{array}$ & $\begin{array}{l}\text { One end of cylinder moves } \\
\text { the other does not, same as } \\
\# 6-5 \text {. }\end{array}$ & Same as \#6-5. & $6-6$ & Minor consequence. \\
\hline
\end{tabular}

(6) Install the lifting bar, and lift the cylinder.

\begin{tabular}{|c|c|c|c|c|c|c|}
\hline Part of & $\begin{array}{l}\text { Incomplete } \\
\text { installation }\end{array}$ & Same as $\# 5-28$. & Same as $\# 5-28$. & None. & $6-7$ & Low likelihood. \\
\hline \multicolumn{7}{|c|}{ (7) Place the cylinder on the trolley. } \\
\hline Part of & Fails during lift & $\begin{array}{l}\text { Crane or rigging fails } \\
\text { (broken cables, etc.). }\end{array}$ & Same as \#5-30. & None. & $6-8$ & $\begin{array}{l}\text { Low likelihood. Rigging is } \\
\text { certified by non- } \\
\text { destructive examination. }\end{array}$ \\
\hline $\begin{array}{l}\text { As well } \\
\text { as }\end{array}$ & $\begin{array}{l}\text { Unwanted } \\
\text { action }\end{array}$ & $\begin{array}{l}\text { Crane operator mis-handles } \\
\text { lift. }\end{array}$ & Same as \#5-29. & None. & $6-9$ & Low likelihood. \\
\hline
\end{tabular}




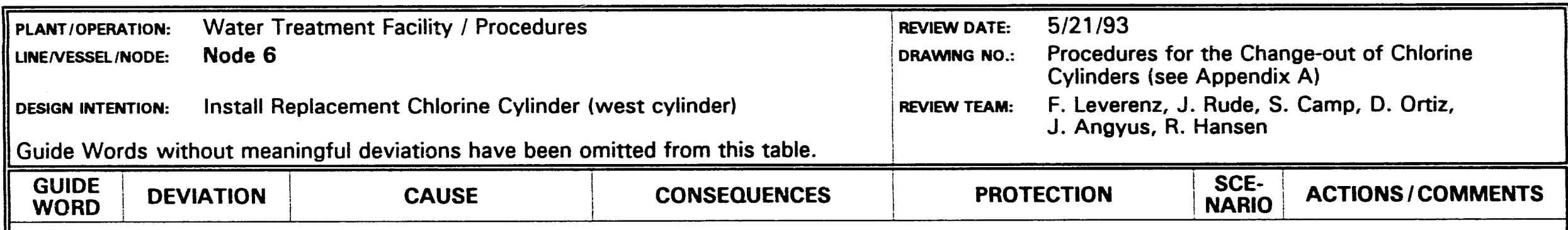

(8) Remove the lifting bar, removing it from the immediate area.

\begin{tabular}{|c|c|c|c|c|c|c|}
\hline No & Skip step & Bar is not removed. & $\begin{array}{l}\text { Delay in the replacement of } \\
\text { the cylinder. }\end{array}$ & None. & $6-10$ & Minor consequence. \\
\hline
\end{tabular}

(9) Secure the cylinder to the trolley with chain binders (2).

\begin{tabular}{|c|c|c|c|c|c|c|}
\hline No & Skip step & $\begin{array}{l}\text { Plant operator does not } \\
\text { install chain binders. }\end{array}$ & $\begin{array}{l}\text { No consequences except } \\
\text { chains dragging as trolley } \\
\text { pushed into building. }\end{array}$ & Sound of dragging chains. & $6-11$ & $\begin{array}{l}\text { Low likelihood. Primary } \\
\text { reason for chain binders } \\
\text { as seismic precautions; } \\
\text { seismic activity is small } \\
\text { (below seismic probability } \\
\text { of zone 2). }\end{array}$ \\
\hline
\end{tabular}

(10) Enter the walk-through door, and open the roll-up door.

No meaningful

deviations

(11) Push the trolley and the chlorine cylinder into the building and against the rail stop. Install the wheel chocks.

\begin{tabular}{|c|c|c|c|c|c|c|}
\hline No & Skip step & $\begin{array}{l}\text { Plant operator does not } \\
\text { move the cylinder. }\end{array}$ & $\begin{array}{l}\text { Delay in replacement of } \\
\text { cylinder. }\end{array}$ & $\begin{array}{l}\text { Position noted by rest of } \\
\text { staff. }\end{array}$ & $6-12$ & Minor consequences. \\
\hline \multirow[t]{2}{*}{ Part of } & $\begin{array}{l}\text { Part of step } \\
\text { skipped }\end{array}$ & $\begin{array}{l}\text { Wheel chocks are not } \\
\text { installed. }\end{array}$ & $\begin{array}{l}\text { Precaution (against } \\
\text { movement) not in place. }\end{array}$ & $\begin{array}{l}\text { Missing chocks noted by } \\
\text { staff during routine checks. } \\
\text { [-HF: chocks are not readily visible } \\
\text { os they are undor tank.] }\end{array}$ & $6-13$ & No direct consequence. \\
\hline & Not positioned & $\begin{array}{l}\text { Plant operator does not } \\
\text { push the cylinder (on } \\
\text { trolley) in far enough. }\end{array}$ & $\begin{array}{l}\text { When the regulator is } \\
\text { installed lines are damaged } \\
\text { by stretching. Low or no } \\
\mathrm{Cl}_{2} \text { flows to the chlorinator } \\
\text { when the cylinder is put in } \\
\text { use (see also \#1-9). }\end{array}$ & $\begin{array}{l}\text { 1) Serviceman notes the } \\
\text { position and requires } \\
\text { correction. } \\
\text { [+HF: position is noted whon } \\
\text { lines do not roadily reach } \\
\text { cylinder.] } \\
\text { 2) Step } 19 \text { leak check. }\end{array}$ & $6-14$ & Sufficient protection. \\
\hline
\end{tabular}




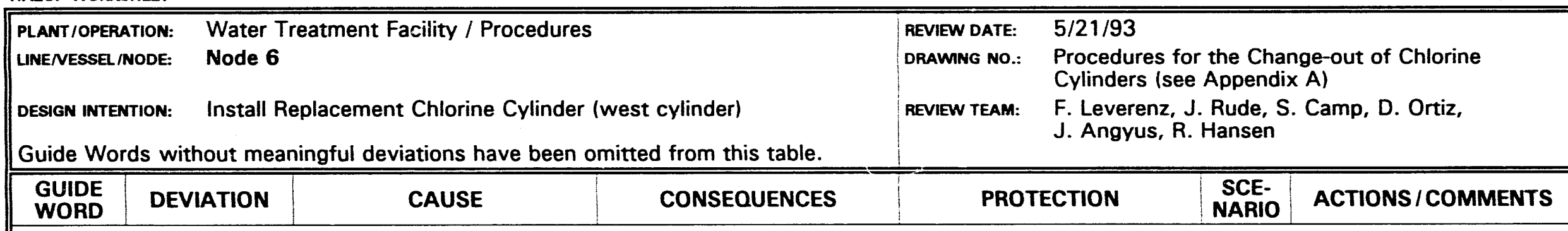

(12) Request the chlorine serviceman to remove the protective hood from the chlorine cylinder.

\begin{tabular}{|c|c|c|c|c|c|}
\hline No & Skip step & $\begin{array}{l}\text { Serviceman does not } \\
\text { remove hood. }\end{array}$ & Delay in replacement. & Noted by staff. & $6-15$ \\
\hline
\end{tabular}

(13) Observe the position of cylinder angle valves. If the valves are not in vertical alignment, loosen the chain binders and rotate the cylinder to obtain vertical alignment, and then tighten the chain binders.

\begin{tabular}{|c|c|c|c|c|c|}
\hline No & Skip step & $\begin{array}{l}\text { Serviceman does not } \\
\text { vertically align the cylinder. } \\
\text { l-HF: alignment done by observation } \\
\text { of cylinder connections } \\
\text { i +HF: serviceman has considerable } \\
\text { oxperience with connections.] }\end{array}$ & $\begin{array}{l}\text { Potential to for liquid } \\
\text { chlorine to enter the ejector } \\
\text { and over chlorinate; } \\
\text { potential for } \mathrm{Cl}_{2} \text { release } \\
\text { from the water. } \\
\text { Release potential unknown. }\end{array}$ & $6-16$ & $\begin{array}{l}\text { Consult the vendor on this } \\
\text { scenario and the expected } \\
\text { system response. } \\
\text { Estimate the amount of } \\
\mathrm{Cl}_{2} \text { release potential. }\end{array}$ \\
\hline Part of & Part of step & $\begin{array}{l}\text { Chains are not tightened } \\
\text { after alignment. }\end{array}$ & No consequence expected. & $6-17$ & $\begin{array}{l}\text { No consequence } \\
\text { expected. }\end{array}$ \\
\hline
\end{tabular}

(14) Chlorine serviceman dons the facemask respirator, and operator dons self-contained breathing apparatus (SCBA). Then they verify the operation of the personal protective equipment.

\begin{tabular}{|c|c|c|c|c|c|c|}
\hline No & Skip step & $\begin{array}{l}\text { Neglect to wear personal } \\
\text { protective equipment. }\end{array}$ & $\begin{array}{l}\text { Loss of protection for } \\
\text { scenarios where needed. }\end{array}$ & & $6-18$ & No direct consequence. \\
\hline \multicolumn{7}{|c|}{ (15) Verify that the chlorine cylinder gas angle valve is closed. } \\
\hline No & Skip step & $\begin{array}{l}\text { Serviceman does not verify } \\
\text { it is closed. }\end{array}$ & $\begin{array}{l}\text { At Step } 16, \mathrm{Cl}_{2} \text { is released } \\
\text { when the cap is removed if } \\
\text { the valve is not fully closed. } \\
\text { Same as } \# 5-5 \text {. }\end{array}$ & $\begin{array}{l}\text { At Step } 16 \text {, the cap is } \\
\text { opened slowly while } \\
\text { checking for leaks. } \\
\text { I+HF: servicoman experioncod with } \\
\text { importance of this check. } 1 \\
\text { Same mitigation as } \# 5-5 \text {. }\end{array}$ & $6-19$ & Sufficient protection. \\
\hline
\end{tabular}




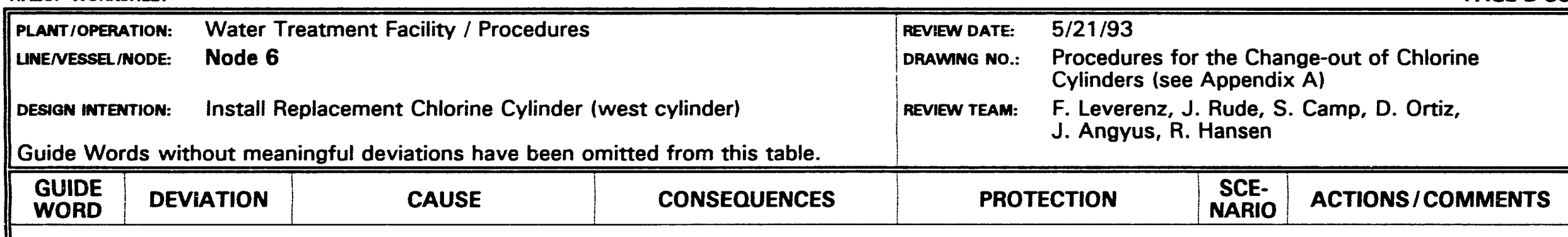

(16) Check for ieaks while slowly removing the protective cap from the cylindier gas angle valve.

\begin{tabular}{|c|c|c|c|c|c|c|}
\hline $\begin{array}{l}\text { More/ } \\
\text { Part of }\end{array}$ & $\begin{array}{l}\text { Too fast/not } \\
\text { check }\end{array}$ & $\begin{array}{l}\text { Serviceman opens the cap } \\
\text { too quickly or does not } \\
\text { check for leaks. } \\
\text { 1+HF: sorviceman experienced with } \\
\text { importance of this check.1 }\end{array}$ & $\begin{array}{l}\text { If valve is open or leaking, } \\
\text { the release of } \mathrm{Cl}_{2} \text { is possible } \\
\text { (amount depends on valve } \\
\text { opening). } \\
\text { Same as } \# 5-5 \text {. }\end{array}$ & $\begin{array}{l}\text { Mitigation: } \mathrm{Cl}_{2} \text { alarm with } \\
\text { emergency response and } \\
\text { same mitigation as } \# 5-5 \text {. }\end{array}$ & $6-20$ & Cause unlikely \\
\hline
\end{tabular}

(17) Clean the sealing surface of the gas angle valve and the vacuum regulator. Visually inspect the regulator valve body for damage.

\begin{tabular}{|c|c|c|c|c|c|c|}
\hline No & Skip step & $\begin{array}{l}\text { Serviceman does not } \\
\text { clean/check sealing surface } \\
\text { of angle valve or vacuum } \\
\text { regulator. }\end{array}$ & $\begin{array}{l}\text { Possible seal leak at } \\
\text { Step } 18 \text { or leak from } \\
\text { damaged regulator. } \\
\mathrm{Cl}_{2} \text { release at Step } 19 \text { same } \\
\text { as } \# 5-5 \text {. }\end{array}$ & $\begin{array}{l}\text { Leak check at Step } 19 \text {. } \\
\text { l+HF: serviceman experienced with } \\
\text { importance of this check.I } \\
\text { Mitigation: } \mathrm{Cl}_{2} \text { alarm with } \\
\text { emergency response and } \\
\text { same mitigation as } \# 5-5 \text {. }\end{array}$ & $6-21$ & Low likelihood. \\
\hline
\end{tabular}

(18) Install a new lead seal. Attach the regulator to the cylinder gas valve, and secure it in place by tightening the yoke assembly.

\begin{tabular}{|c|c|c|c|c|c|c|}
\hline Part of & $\begin{array}{l}\text { Incorrect lead } \\
\text { seal } \\
\text { installation }\end{array}$ & $\begin{array}{l}\text { Serviceman does not install } \\
\text { the lead seal or uses the old } \\
\text { seal. } \\
\text { + HF: exporienced sorvicoman knows } \\
\text { importance of new seal.] }\end{array}$ & Same as \#6-21. & Same as \#6-21. & $6-22$ & Same as $\# 6-21$. \\
\hline Less & $\begin{array}{l}\text { Not tight } \\
\text { enough }\end{array}$ & $\begin{array}{l}\text { Serviceman does not } \\
\text { tighten the yoke assembly } \\
\text { enough. } \\
\text { I+HF: sorviceman experienced with } \\
\text { cylinder yoke attachment.] }\end{array}$ & Same as $\# 6-21$. & Same as \#6-21. & $6-23$ & Same as \#6-21. \\
\hline More & Too tight & $\begin{array}{l}\text { Serviceman over-tightens } \\
\text { the yoke assembly. } \\
\text { I+HF: sorviceman exporienced with } \\
\text { cylinder yoke attachment.] }\end{array}$ & $\begin{array}{l}\text { Breaks the yoke; } \\
\text { replacement of cylinder is } \\
\text { delayed. }\end{array}$ & & $6-24$ & Low likelihood. \\
\hline
\end{tabular}




\begin{tabular}{|c|c|c|c|c|c|c|c|}
\hline $\begin{array}{l}\text { PLANT/OPERATION: } \\
\text { UNE/VESSEL /NODE: } \\
\text { DESIGN INTENTION. }\end{array}$ & 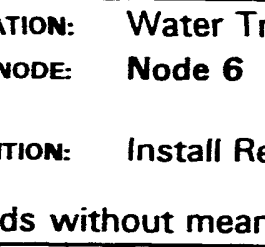 & $\begin{array}{l}\text { Water Treatment Facility / Procedures } \\
\text { Node } 6\end{array}$ & $\begin{array}{l}\text { (west cylinder) } \\
\text { mitted from this table. }\end{array}$ & $\begin{array}{l}\text { REVIEW DATE: } \\
\text { DRAWING NO. } \\
\text { REVIEW TEAM: }\end{array}$ & \multicolumn{3}{|c|}{$\begin{array}{l}5 / 21 / 93 \\
\text { Procedures for the Change-out of Chlorine } \\
\text { Cylinders (see Appendix A) } \\
\text { F. Leverenz, J. Rude, S. Camp, D. Ortiz, } \\
\text { J. Angyus, R. Hansen }\end{array}$} \\
\hline $\begin{array}{l}\text { GUIDE } \\
\text { WORD } \\
\end{array}$ & DEVIATTION & CAUSE & CONSEQUENCES & \multicolumn{2}{|c|}{ PROTECTION } & $\begin{array}{l}\text { SCE- } \\
\text { NARIO }\end{array}$ & ACTIONS/COMMENTS \\
\hline $\begin{array}{l}\text { Other } \\
\text { than }\end{array}$ & $\begin{array}{l}\text { Wrong angle } \\
\text { valve }\end{array}$ & $\begin{array}{l}\text { Serviceman installs } \\
\text { regulator on the liquid } \\
\text { valve. } \\
1+H F \text { : servicemen experienced with } \\
\text { attachmont and must instell upside } \\
\text { down.l }\end{array}$ & Same as \#6-16. & \multicolumn{2}{|c|}{$\begin{array}{l}\text { Same as } \# 6-16 \text {. } \\
\text { Tour surveillance } \\
\text { notices regulator upside } \\
\text { down. }\end{array}$} & $6-25$ & Low likelihood. \\
\hline \multicolumn{8}{|c|}{$(19)$} \\
\hline Part of & $\begin{array}{l}\text { Not check for } \\
\text { leaks }\end{array}$ & $\begin{array}{l}\text { Serviceman does not check } \\
\text { for leaks. }\end{array}$ & $\begin{array}{l}\text { Loss of protection in } \\
\text { previous scenarios. }\end{array}$ & & & $6-26$ & No direct consequence. \\
\hline More & Opens too fast & $\begin{array}{l}\text { Serviceman opens valve too } \\
\text { fast. }\end{array}$ & $\begin{array}{l}\text { Releases more chlorine than } \\
\text { necessary for leak } \\
\text { detection. } \\
\text { No health effects expected. }\end{array}$ & \multicolumn{2}{|l|}{ None. } & $6-27$ & Low likelihood. \\
\hline \multicolumn{8}{|c|}{$(20)$} \\
\hline & $\begin{array}{l}\text { No meaningful } \\
\text { deviations }\end{array}$ & & & & & & \\
\hline \multicolumn{8}{|c|}{$(21)$} \\
\hline $\begin{array}{l}\text { No or } \\
\text { Part of }\end{array}$ & $\begin{array}{l}\text { Skip step or } \\
\text { part of the } \\
\text { step }\end{array}$ & $\begin{array}{l}\text { Plant operator does not } \\
\text { open the vaives. }\end{array}$ & $\begin{array}{l}\text { Replacement chlorine not } \\
\text { available; loss of } \\
\text { chlorination. } \\
\text { Same as \#1-1. }\end{array}$ & \multicolumn{2}{|c|}{$\begin{array}{l}\text { 1) High vacuum alarm. } \\
\text { Residual } \mathrm{Cl}_{2} \text { surveillance } \\
\text { checks (see also } \# 1-1 \text {. } \\
\text { Protection } 3 \text { ). }\end{array}$} & $6-28$ & Sufficient protection. \\
\hline Less & $\begin{array}{l}\text { Not opened } \\
\text { completely }\end{array}$ & $\begin{array}{l}\text { Plant operator does not } \\
\text { open one or both of the } \\
\text { valves completely. }\end{array}$ & No consequence. & & & $6-29$ & \\
\hline $\begin{array}{l}\text { Other } \\
\text { than }\end{array}$ & $\begin{array}{l}\text { Wrong valve } \\
\text { selected }\end{array}$ & $\begin{array}{l}\text { Plant operator opens the G3 } \\
\text { valve instead of the G5 } \\
\text { valve. } \\
1-\mathrm{HF} \text { : soveral valves in one location. } 1\end{array}$ & $\begin{array}{l}\text { Draws } \mathrm{Cl}_{2} \text { from both } \\
\text { cylinders at the same time. } \\
\text { Potential for loss of } \\
\text { chlorination (see } \# 1-1 \text { ). }\end{array}$ & \multicolumn{2}{|c|}{$\begin{array}{l}\text { 1) Surveillance checks } \\
\text { weight of cylinders. } \\
\text { 2) Surveillance checks rate } \\
\text { indicators on regulators. }\end{array}$} & $6-30$ & Minor consequences. \\
\hline
\end{tabular}




\begin{tabular}{|c|c|c|c|c|c|c|c|}
\hline $\begin{array}{l}\text { PLANT/OPERATION: } \\
\text { LNE/VESSEL/NODE: } \\
\text { DESIGN INTENTION: }\end{array}$ & $\begin{array}{l}\text { ITION: } \\
\text { NODE: }\end{array}$ & \multicolumn{2}{|c|}{$\begin{array}{l}\text { Water Treatment Facility / Procedures } \\
\text { Node } 6\end{array}$} & $\begin{array}{l}\text { REVIEW DATE: } \\
\text { DRAWWG NO.: } \\
\text { REVIEW TEAME: }\end{array}$ & \multicolumn{3}{|c|}{$\begin{array}{l}\text { 5/21/93 } \\
\text { Procedures for the Change-out of Chlorine } \\
\text { Cylinders (see Appendix A) } \\
\text { F. Leverenz, J. Rude, S. Camp, D. Ortiz, } \\
\text { J. Angyus, R. Hansen }\end{array}$} \\
\hline $\begin{array}{l}\text { GUIDE } \\
\text { WORD }\end{array}$ & DEVIATION & CAUSE & CONSEQUENCES & PROT & ETION & $\begin{array}{l}\text { SCE- } \\
\text { NARIO }\end{array}$ & ACTIONS/COMMENTS \\
\hline \multicolumn{8}{|c|}{ (22) } \\
\hline & $\begin{array}{l}\text { No meaningful } \\
\text { deviations }\end{array}$ & & & & & & \\
\hline & \multicolumn{7}{|c|}{ Report any deficiencies to the supervisor for initiation of necessary corrective action. } \\
\hline \multirow[t]{2}{*}{ No } & Skip step & Notification not made. & Delay in completing action. & & & 6-31 & Minor consequences. \\
\hline & \multicolumn{7}{|c|}{ Notify the Hanford Fire Department and the 384 Powerhouse that the chlorine cylinder change-out activities are complete. } \\
\hline \multirow[t]{3}{*}{ No } & Skip step & Notification not made. & No consequence. & & & $6-32$ & Minor consequence. \\
\hline & Close & \multicolumn{2}{|c|}{ Close the roll-up door, and exit through the walk-through door. } & & & & \\
\hline & $\begin{array}{l}\text { No meaningful } \\
\text { deviations }\end{array}$ & & & & & & \\
\hline
\end{tabular}

Hazerd and Operability Study Workshoet 


\section{APPENDIX C}

\section{ESTIMATING THE EFFECTS OF CHLORINE RELEASES}




\section{APPENI)IX C: ESTIMATING THE EFFECTS OF CHLORINE RELEASES}

Information contained in this appendix was excerpted, with permission, from Estimating the Area Affected by a Chlorine Release (The Chlorine Institute, 1991). The computer dispersion model used by The Chlorine Institute to generate release scenarios was based on generic industrial accidents and atmospheric conditions. The results depend on the atmospheric conditions and wind speeds assumed for the releases as well as on the terrain. They serve as an aid to estimating the range of potential consequences of chlorine releases. The HAZOP study team used this reference for the release and dispersion of chlorine to understand the potential consequences and impacts of releases.

\section{C.1 Characteristics of Chlorine Releases}

Unintended chlorine releases have occurred as a result of industrial accidents involving equipment such as tanks, pipelines, relief valves, and vents.

Chlorine releases can be modeled as either instantaneous puff releases or continuous releases. During an instantaneous release, such as a cylinder rupture, large amounts of chlorine are released in a relatively short period of time. In a continuous release, such as the failure of a gasket, the chlorine release rate is maintained over a period of time until it is controlled or until the cylinder is depleted.

Initially, during a cylinder release, either gaseous or liquid chlorine, or both, may be released. As a result of the release, the pressure and temperature in the cylinder decreases, slowing the release rate. Upon release, pressurized liquid chlorine cools to its boiling point $\left(-29^{\circ} \mathrm{F}\right)$ and boils off. Mixing with the atmosphere is delayed because the liquid must first evaporate. Chlorine vapors, however, mix immediately. If released under pressure, liquid chlorine can flash to a vapor, resulting in a two-phased jet release.

During the intermediate phases of a chlorine release, the chlorine is most influenced by atmospheric conditions. It continues to mix with the air and with moisture in the air. Depending on atmospheric conditions, aerosols may form. Eventually, a dense gas plume forms. This heavier-than-air plume remains at ground level as it moves downwind until, through dilution, its density equals the density of air.

Because of the atmospheric variability, stability classes are used to predict the dispersion of the plume. In the early morning, the atmosphere is stable. Daytime solar heating creates air movement and an unstable atmosphere. Atmospheric stability classes range from "very unstable" Class A to "very stable" Class G. Dispersion is also affected by the wind, the mixing height, and the terrain. 


\section{C.2 Chlorine Release Scenarios}

The consequences of the accident scenarios identified during the HAZOP study can be categorized as:
- Chlorine cylinder releases
- Process line breaks and releases
- Process equipment leaks.

The potential accident scenarios are identified in the HAZOP Study Worksheets (Appendix B).

To estimate the potential consequences and impacts of these accidents, release scenarios were selected from Estimating the Area Affected by a Chlorine Relecase. The scenarios are based on typical industrial accidents with conservative modeling assumptions. Five accident scenarios were selected for consideration:

1. A 1-ton cylinder is struck and its liquid valve is sheared off, resulting in the release of liquid chlorine.

2. Half-inch tubing is sheared off and chlorine gas is released (modeled with infinite supply).

3. A 1-inch pipe is sheared off and chlorine gas is released (modeled with infinite supply).

4. Half-inch tubing is sheared off and liquid chlorine is released (modeled with infinite supply).

5. A 1-inch pipe is sheared off and liquid chlorine is released (modeled with infinite supply).

The assumptions for these five release scenarios are

- Three-foot release height

- Ambient air temperature of $68^{\circ} \mathrm{F}$

- Ambient relative humidity of 50 percent

- $\quad$ Liquid or gaseous chlorine at $68^{\circ} \mathrm{F}$

- $\quad$ Changes in ambient temperature or relative humidity assumptions have little effect on dispersion. Changes in assumptions about temperature and pressure of chlorine prior to release can significantly affect dispersion. 
- Five-mile-per-hour wind speed. Because ambient concentration is inversely proportional to wind speed, concentrations can be converted to other wind conditions by dividing 5 miles per hour by the actual wind speed and multiplying the result by the concentration.

- Average wind fluctuation of approximately $5^{\circ}$. If wind shifts are greater, the area impacted by the plume is greater.

- $\quad$ Stability Classes:

-- Stability Class B: Strong and moderate solar radiation with low wind speed. Occurs during the day, generally in the mornings, with clear skies and wind speed less than 10 miles per hour.

-- $\quad$ Stability Class F: Occurs at night, with wind speed less than 6 miles per hour, and with less than 40 percent cloud cover.

-- Stability Class D: Used when classes B and F are not applicable.

\section{C.3 Predicted Chlorine Consequences}

Figures C-1 through C-5 show graphically the areas potentially affected by chlorine releases for five generic accident scenarios*. Downstream distances are depicted at which chlorine concentrations exceed 25 parts per million (ppm) and $10 \mathrm{ppm}$.

The dispersion distances and downwind concentrations of chlorine resulting from the scenario modelling are summarized in Table $\mathrm{C}-1$. The $25-\mathrm{ppm}$ chlorine concentration is the immediately-dangerous-to-life-or-health (IDLH) level for chlorine, and $10 \mathrm{ppm}$ is 40 percent of the IDLH. Ten ppm was chosen as a reference point for emergency planning because of the uncertainty in dispersion modeling.

The graphs in Figures C.I through C-5 are truncated on the right-hand side of the $x$-axis. In fact, these curves extend to meet the $x$-axis. Limitations in display prevented the full extension from heing shown. 


\section{C.4 Potentlal Impacts of Chlorine Releases at the Hanford 300-Area Water Treatment Facility}

If a large chlorine release occurs from the Hanford 300-Area Water Treatment Facility, wind from the northwest, west, and southwest would disperse it across the Columbia River to the residences on the far side, more than 3/4 of a mile away. In addition, boaters on the river and any workers occupying the pump house would also likely be exposed. The pump house, however, is normally unoccupied.

Wind from the north would carry a large chlorine plume to the 337 Office Building, resulting in the potential exposure of its more than 300 occupants. Small releases of chlorine would probably result in minor irritations to workers in the area. 
Table C-1. Summary of Dispersion Distances and Downwind Concentrations for Chlorine Release Scenarios

\begin{tabular}{|c|c|c|c|c|c|c|}
\hline \multirow[t]{2}{*}{$\begin{array}{c}\text { Scenario } \\
\text { Description }\end{array}$} & \multicolumn{2}{|c|}{$\begin{array}{l}\text { Stability Class B } \\
\text { Distance in } \\
\text { feet and miles }\end{array}$} & \multicolumn{2}{|c|}{$\begin{array}{l}\text { Stability Class D } \\
\text { Distance in } \\
\text { feet and miles }\end{array}$} & \multicolumn{2}{|c|}{$\begin{array}{c}\text { Stability Class F } \\
\text { Distance in } \\
\text { feet and miles }\end{array}$} \\
\hline & 25 ppm & 10 ppm & $25 \mathrm{ppm}$ & 10 ppm & $25 \mathrm{ppm}$ & 10 ppm \\
\hline $\begin{array}{l}\text { 1) A 1-ton cylinder } \\
\text { is struck and its } \\
\text { liquid valve is } \\
\text { sheared off. Liquid } \\
\text { chlorine is released } \\
\text { from a } 3 / 8 \text {-inch } \\
\text { hole. }\end{array}$ & $\begin{array}{c}3,600 \\
0.7\end{array}$ & $\begin{array}{c}5,400 \\
1.0\end{array}$ & $\begin{array}{c}5,400 \\
1.0\end{array}$ & $\begin{array}{c}9,600 \\
1.8\end{array}$ & $\begin{array}{c}10,800 \\
2.0\end{array}$ & $\begin{array}{c}18,000 \\
3.4\end{array}$ \\
\hline $\begin{array}{l}\text { 2) Half-inch, type-K } \\
\text { copper tubing is } \\
\text { sheared off. } \\
\text { Chlorine gas is } \\
\text { released (modeled } \\
\text { with infinite } \\
\text { supply). }\end{array}$ & $\begin{array}{l}800 \\
0.2\end{array}$ & $\begin{array}{c}1,200 \\
0.2\end{array}$ & $\begin{array}{c}1,200 \\
0.2\end{array}$ & $\begin{array}{c}2,100 \\
0.4\end{array}$ & $\begin{array}{c}1,800 \\
0.3\end{array}$ & $\begin{array}{c}3,300 \\
0.6\end{array}$ \\
\hline $\begin{array}{l}\text { 3) A 1-inch } \\
\text { schedule- } 80 \text { pipe is } \\
\text { sheared off. } \\
\text { Chlorine gas is } \\
\text { released (modeled } \\
\text { with infinite } \\
\text { supply). }\end{array}$ & $\begin{array}{c}1,600 \\
0.3\end{array}$ & $\begin{array}{c}2,800 \\
0.5\end{array}$ & $\begin{array}{c}2,600 \\
0.5\end{array}$ & $\begin{array}{c}4,400 \\
0.8\end{array}$ & $\begin{array}{c}4,200 \\
0.8\end{array}$ & $\begin{array}{c}7,400 \\
1.4\end{array}$ \\
\hline $\begin{array}{l}\text { 4) Half-inch, type-K } \\
\text { copper tubing is } \\
\text { sheared off. Liquid } \\
\text { chlorine is released } \\
\text { (modeled with } \\
\text { infinite supply). }\end{array}$ & $\begin{array}{c}2,000 \\
0.4\end{array}$ & $\begin{array}{c}3,750 \\
0.7\end{array}$ & $\begin{array}{c}3,000 \\
0.6\end{array}$ & $\begin{array}{c}5,500 \\
1.0\end{array}$ & $\begin{array}{c}5,250 \\
1.0\end{array}$ & $\begin{array}{c}9,250 \\
1.8\end{array}$ \\
\hline $\begin{array}{l}\text { 5) A } 1 \text {-inch } \\
\text { schedule- } 80 \text { pipe is } \\
\text { sheared off. Liquid } \\
\text { chlorine is released } \\
\text { (modeled with } \\
\text { infinite supply). }\end{array}$ & $\begin{array}{c}4,000 \\
0.8\end{array}$ & $\begin{array}{c}7,000 \\
1.3\end{array}$ & $\begin{array}{c}7,000 \\
1.3\end{array}$ & $\begin{array}{c}7,000 \\
2.0\end{array}$ & $\begin{array}{c}11,000 \\
2.0\end{array}$ & $\begin{array}{c}18,500 \\
3.5\end{array}$ \\
\hline
\end{tabular}




\section{Scenario Description:}

a. A 1-ton cylinder is struck and its liquid valve is sheared off. Liquid chlorine is released from a $3 / 8$-inch hole.

b. The container is full $=2,000$ pounds $\mathrm{Cl}_{2}$.

c. The valve body has a 3/8-inch hole.

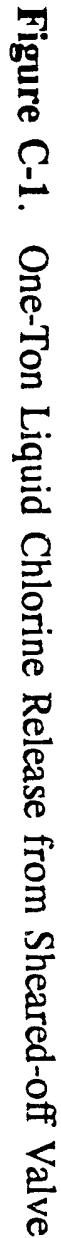

d. Release height is 3 feet. The container is on a concrete slab.

\section{Stability Class B}

Morning - Clear, Low Winds

Y-Axis Distance in Feet

Dark shading Concentration Exceeds 25 ppm Light shading Concentration Exceeds 10 ppm

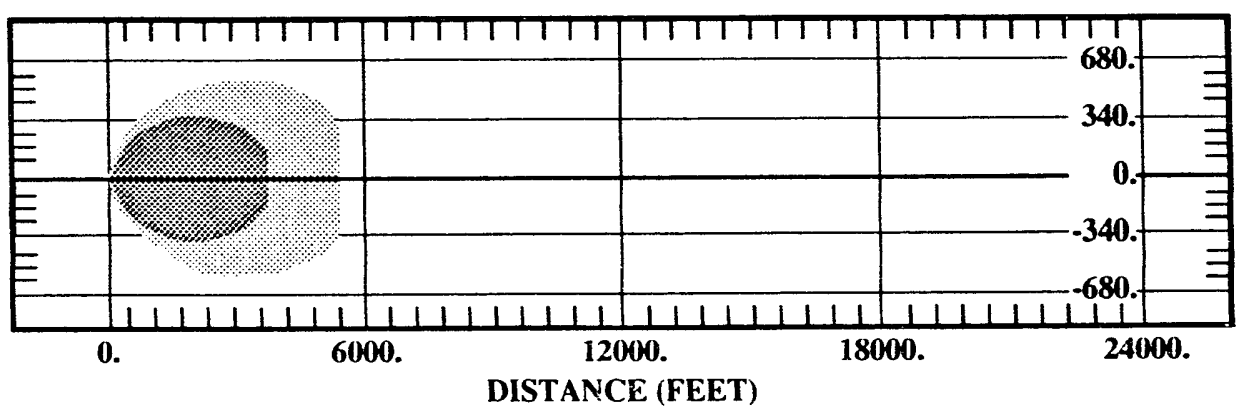

\section{Stability Class D}

All other Conditions

Y-Axis Distance in Feet

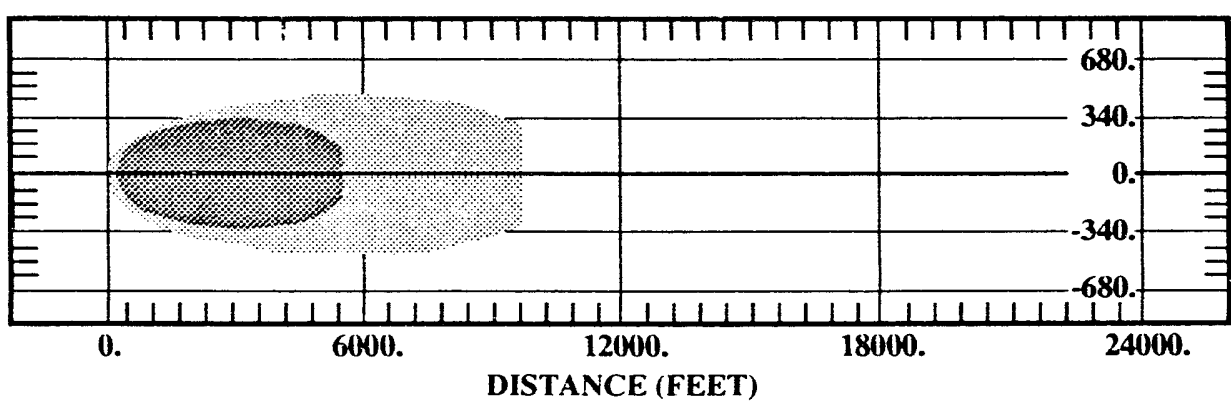

\section{Dark shading \\ Light shading \\ Concentration Exceeds $25 \mathrm{ppm}$ Concentration Exceeds 10 ppm}

\section{Stability Class $\mathbf{F}$}

Nighttime - Mostly Clear Skies, Low Winds

Y-Axis Distance in Feet

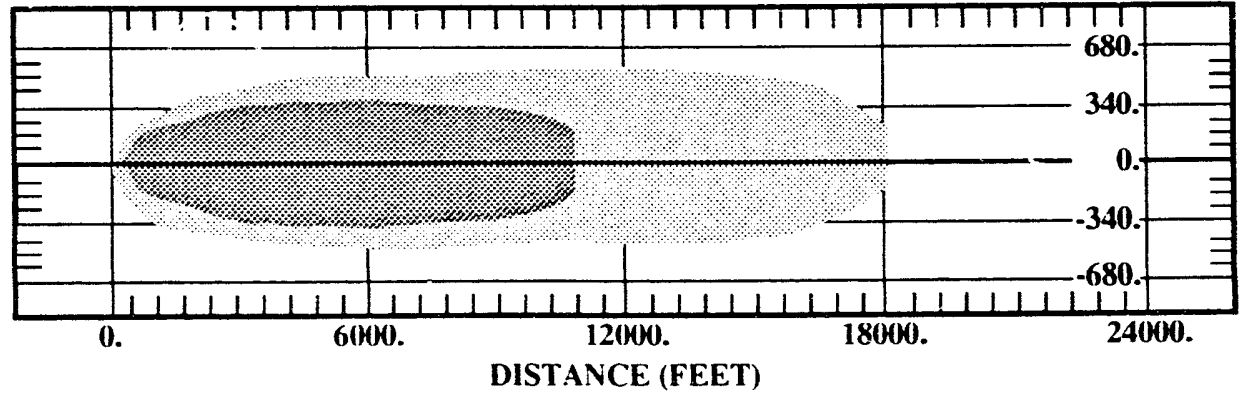


Scenario Description:

a. Half-inch, type-K copper tubing is sheared off. Chlorine gas is released (modeled with infinite supply).

b. Release height is $\mathbf{3}$ feet.

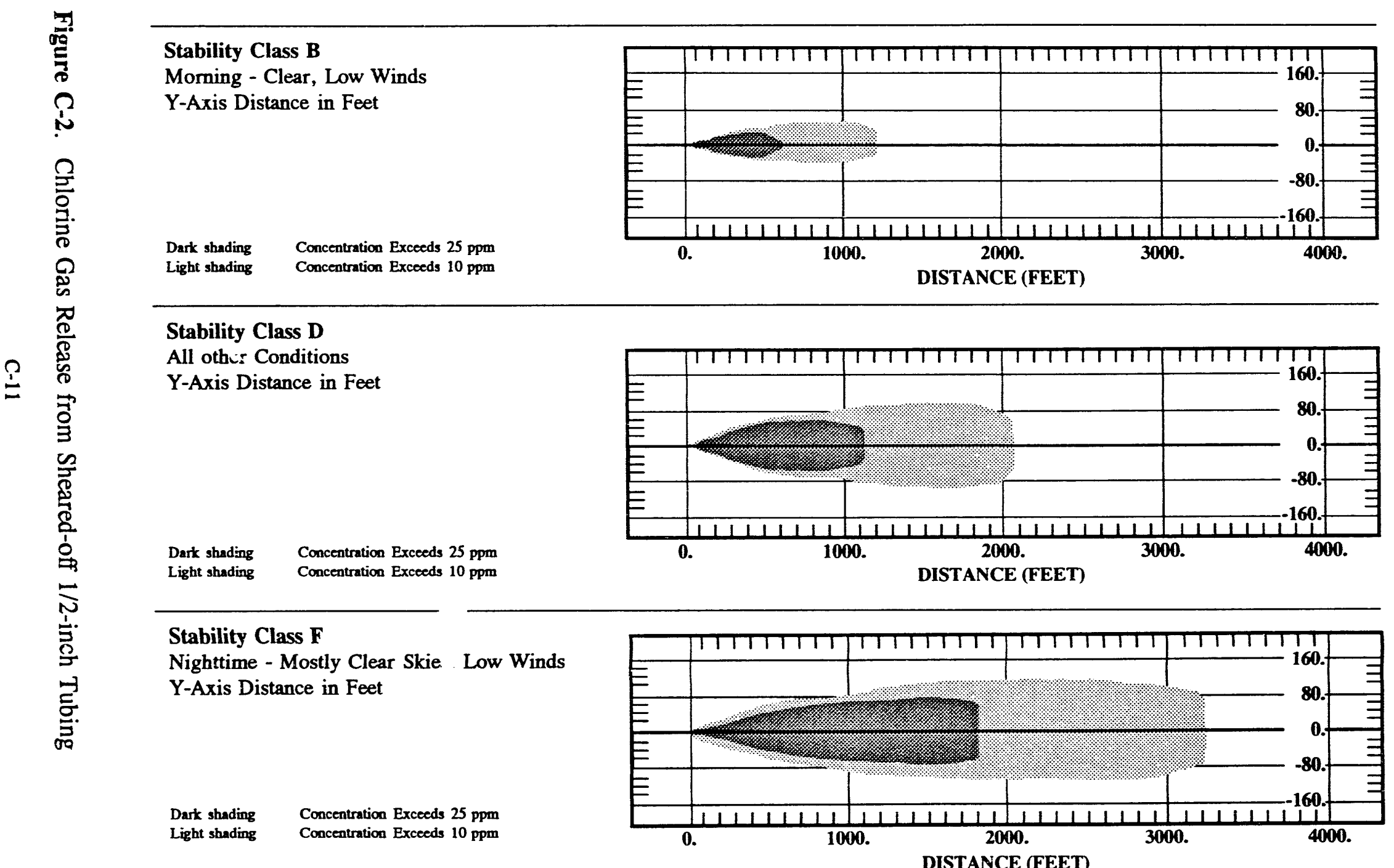


Scenario Description:

a. A 1-inch, schedule-80 pipe is sheared off. Chlorine gas is

released (modeled with infinite supply).

b. Release height is $\mathbf{3}$ feet.

\section{Stability Class B}

Morning - Clear, Low Winds

Y-Axis Distance in Feet

?

Dark shading Concentration Exceods $25 \mathrm{ppm}$

Light shading Concentration Exceeds 10 ppm

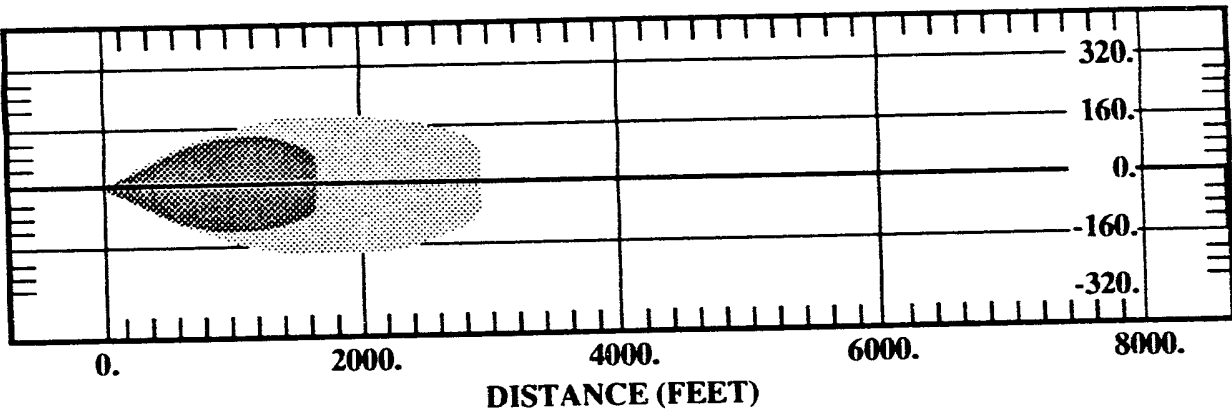

\section{Stability Class D}

All other Conditions

Y-Axis Distance in Feet

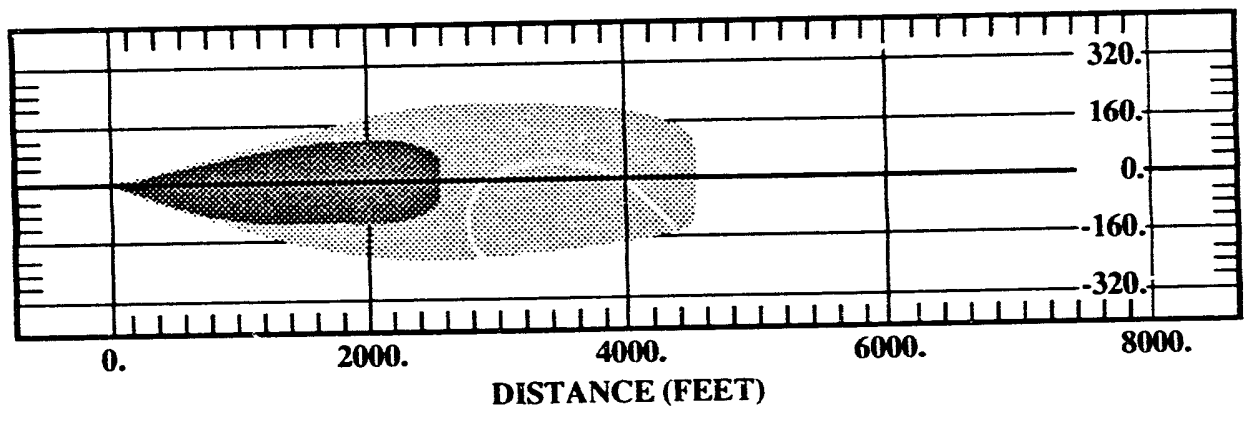

Dark shading Concentration Exceeds $25 \mathrm{ppm}$ Light shading Concentration Exceeds 10 ppm

\section{Stability Class F}

Nighttime - Mostly Clear Skies, Low Winds

Y-Axis Distance in Feet

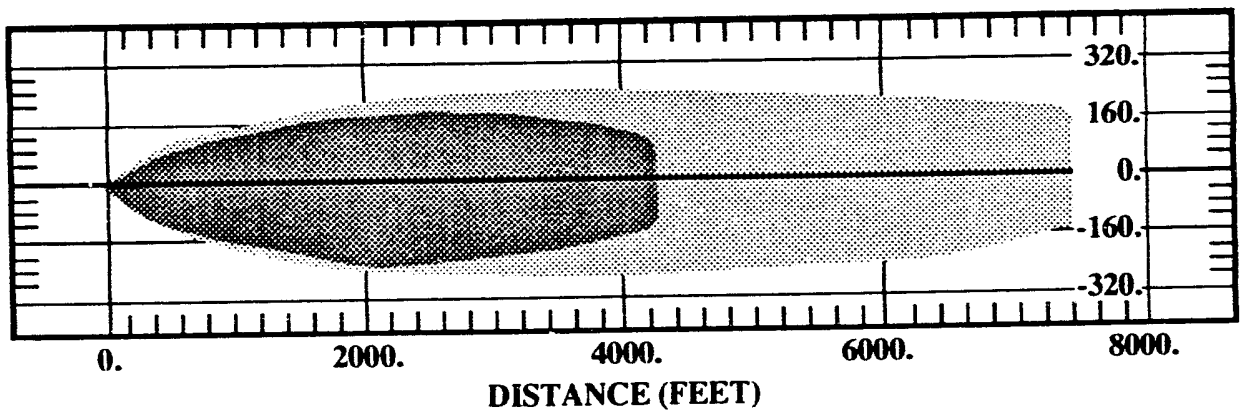


Scenario Description:

a. Half-inch, type-K copper tubing is sheared off. Liquid chlorine is released (modeled with infinite supply).

b. Release height is $\mathbf{3}$ feet.

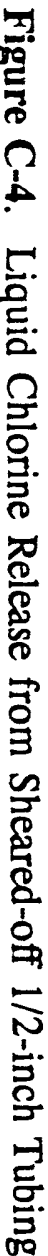

Stability Class B

Moming - Clear, Low Winds

Y-Axis Distance in Feet

Dark shading $\quad$ Concentration Exceeds 25 ppm
Light shading

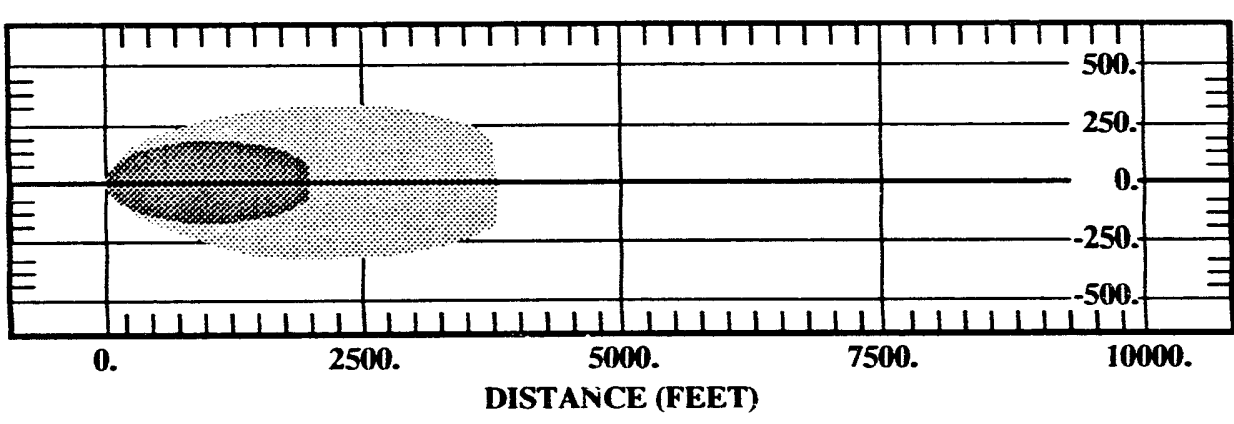

\section{Stability Class D}

All other Conditions

Y-Axis Distance in Feet

3

$\begin{array}{lll}\text { Dark shading } & \text { Concentration Exceeds } 25 \mathrm{ppm} \\ \text { Cight shading } & \text { Concentration Excceds } 10 \mathrm{ppm}\end{array}$

\section{Stability Class F}

Nighttime - Mostly Clear Skies, Low Winds

Y-Axis Distance in Feet

Dark shading

Concentration Exceeds 25 ppm

Light shading

Concentration Exceeds $10 \mathrm{ppm}$
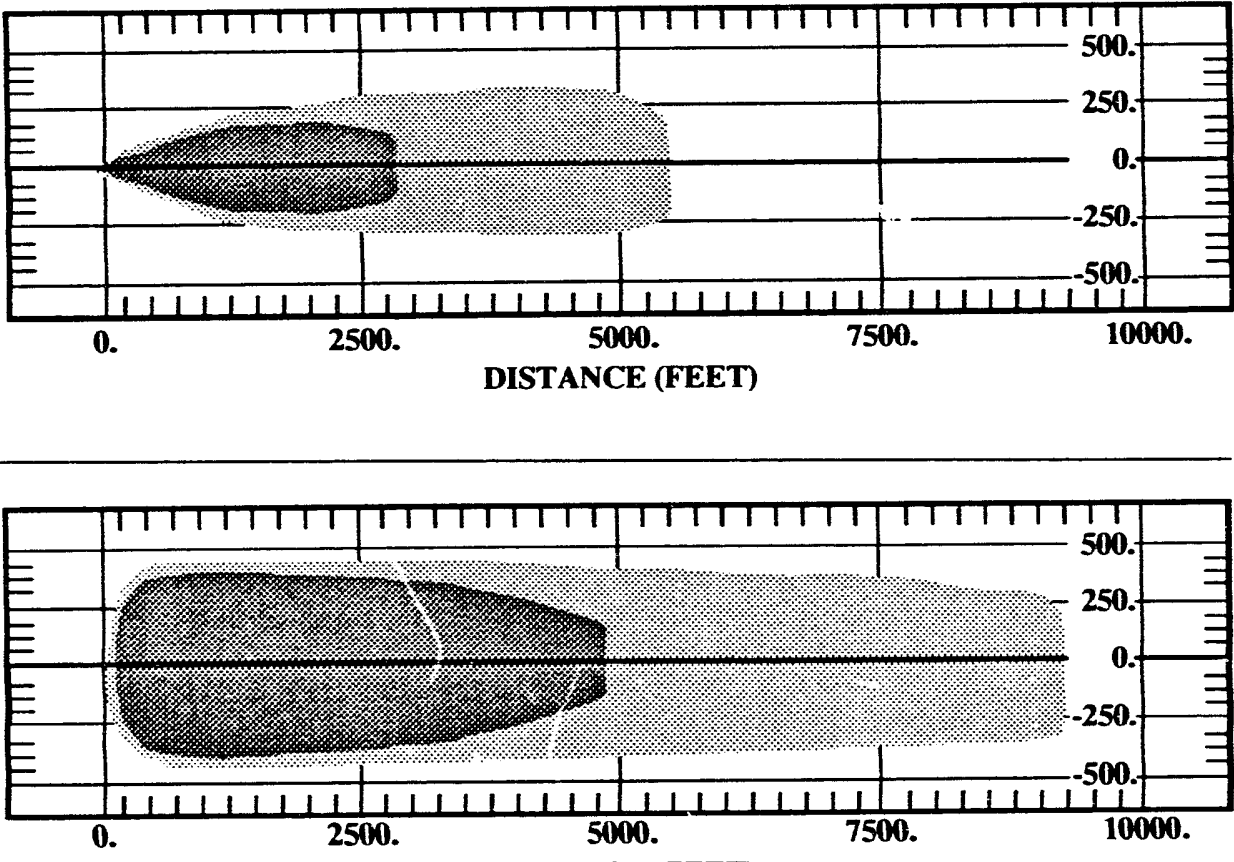

DISTANCE (FEET) 
Scenario Description:

a. A 1-inch, schedule-80 pipe is sheared off. Liquid chlorine is released (modeled with infinite supply).

b. Release height is $\mathbf{3}$ feet.

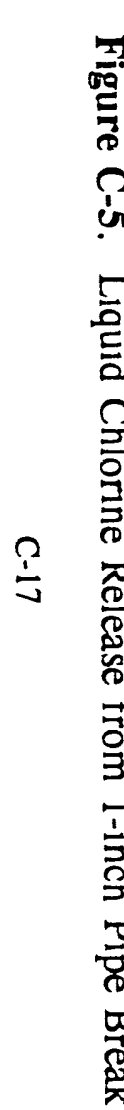

\section{Stability Class B \\ Morning - Clear, Low Winds \\ Y-Axis Distance in Feet \\ Dark shading Concentration Exceeds 25 ppm \\ Concentration Excoeds 10 ppm}

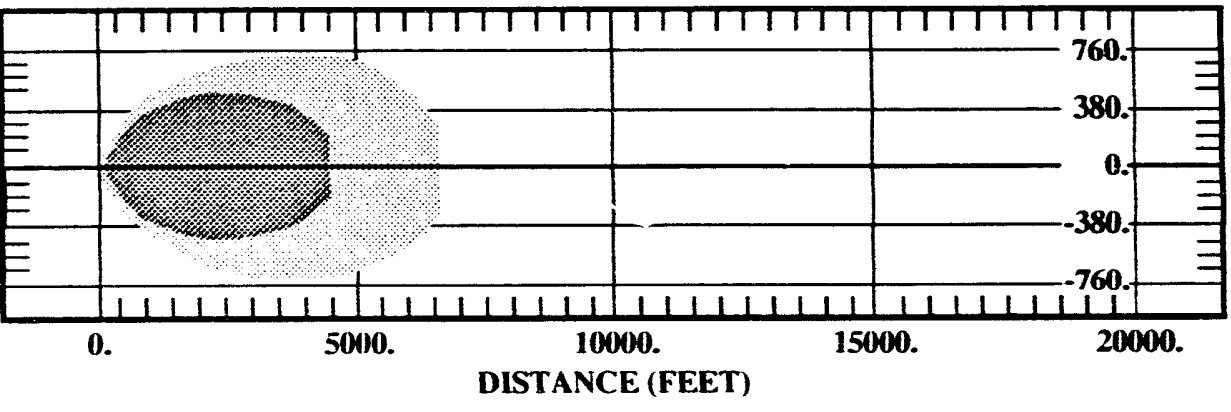

Stability Class D

All other Conditions

Y-Axis Distance in Feet

Dark shading Concentration Exceeds $25 \mathrm{ppm}$ Light shading Concentration Exceeds 10 ppm

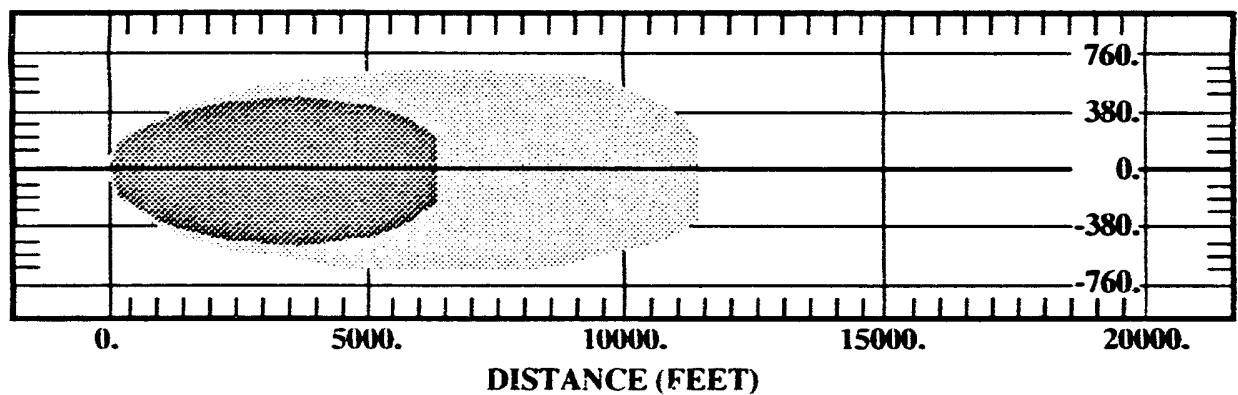

Stability Class F

Nighttime - Mostly Clear Skies, Low Winds

Y-Axis Distance in Feet

Dark shading Light shading
Concentration Exceeds 25 ppm Concentration Exceeds 10 ppm

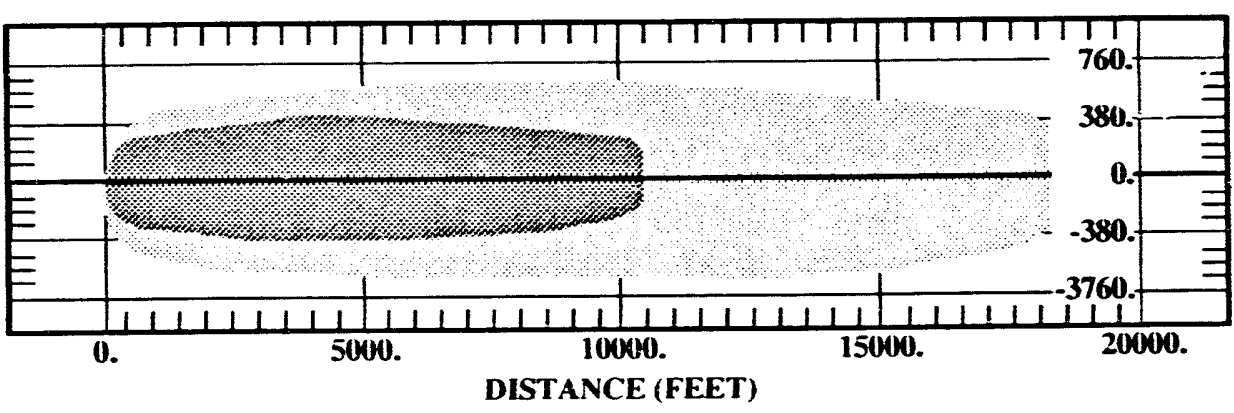


APPENDIX D

MATERIAL SAFETY DATA SHEET

FOR CHLORINE 


\section{APPENDIX D: MATERIAL SAFETY DATA SHEET FOR CHLORINE*}

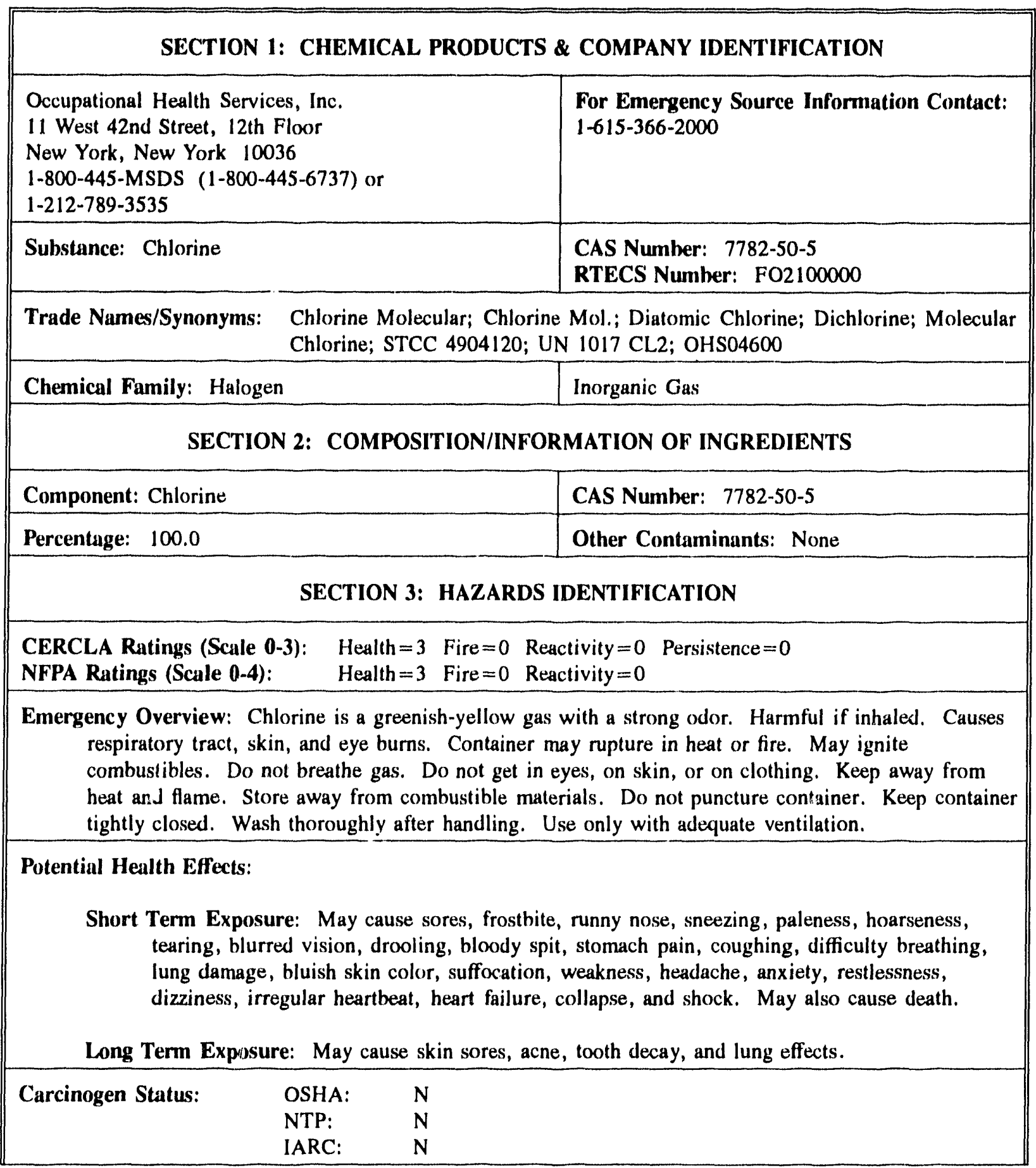

* Adapted by permission of Occupational Health Services, Ine. 


\section{SECTION 4: FIRST AID MEASURES}

Inhalation: First Aid - Remove from exposure area to fresh air immediately. If breathing has stopped, give artificial respiration. Maintain airway and blood pressure and administer oxygen if available. Keep affected person warm and at rest. Treat symptomatically and supportively. Administration of oxygen should be performed by qualified personnel. Get medical attention immediately.

Skin Contact: First Aid - Remove contaminated clothing and shoes immediately. Wash affected area with soap or mild detergent and large amounts of water until no evidence of chemical remains (at least 15-20 minutes). In case of chemical burns, cover area with sterile, dry dressing. Bandage securely, but not too tightly. Get medical attention immediatelv.

Eye Contact: First Aid - Wash eyes immediately with large amounts of water, occasionally lifting upper and lower lids, until no evidence of chemical remains (at least 15-20 minutes). Continue irrigating with normal saline until the $\mathrm{pH}$ has returned to normal (30-60 minutes). Cover with sterile bandages. Get medical attention immediately.

Ingestion: First Aid - Do not use gastric lavage or emesis. Dilute the acid immediately by drinking large quantities of water or milk. If vomiting persists, administer fluids repeatedly. Ingested acid must be diluted approximately 100 fold to render it harmless to tissues. Maintain airway and treat shock (Dreisbach, handbook of poisoning, 12 th ed.). Get medical attention immediately. If vomiting occurs, keep head below hips to help prevent aspiration.

Note to Physician:

Antidote: No specific antidote. Treat symptomatically and supportively.

\section{SECTION 5: FIRE FIGHTING MEASURES}

Fire and Explosion Hazard: Negligible fire hazard when exposed to heat or flame.

Oxidizer: Oxidizers decompose, especially when heated, to yield oxygen or other gases which will increase the burning rate of combustible matter. Contact with easily oxidizable, organic, or other combustible materials may result in ignition, violent combustion or explosion.

Extinguishing Media: Water only, no dry chemical, carbon dioxide or halon (1990 Emergency Response Guidebook, DOT P 5800.5). For larger fires, use water spray or fog (1990 Emergency Response Guidebook, DOT P 5800.5).

Firefighting: Move container from fire area if you can do it without risk. Apply cooling water to sides of containers that are exposed to flames until well after fire is out. Stay away from ends of tanks. For massive fire in cargo area, use unmanned hose holder or monitor nozzles; if this is impossible, withdraw from area and let fire burn. For small fires, contain and let burn; if fire must be fought, water spray or fog is recommended (1990 Emergency Response Guidebook, DOT P 5800.5, guide page 20).

Extinguish using agents suitable for type of fire. Cool containers with flooding amounts of water, apply from as far a distance as possible. Avoid breathing poisonous vapors, keep upwind. Evacuate to a radius of 2,500 feet if material is leaking.

Hazardous Combustion Products: Thermal decomposition products may include toxic and corrosive fumes of chlorine. 


\section{SECTION 6: ACCIDENTAL RELEASE MEASURES}

Occupational Spill: Stop leak if you can do it without risk. Keep combustibles away from spilled material. Keep unnecessary people away; isolate area and deny entry until gas has dispersed. Ventilate closed spaces before entering.

Reportable Quantity (RQ): 10 pounds

The Superfund Amendments and Reauthorization Act (SARA) Section 304 requires that a release equal to or greater than the reportable quantity for this substance be immediately reported to the local emergency planning committee and the state emergency response commission (40 CFR 355.40). If the release of this substance is reportable under CERCLA Section 103, the National Response Center must be notified immediately at (800) $424-8802$ or (202) 426-2675 in the metropolitan Washington, DC, area (40 CFR 302.6).

Soil Spill: Dig a pit, pond, lagoon or holding area to contain liquid or solid material. Dike surface flow using soil, sandhags, foamed polyurethane or foamed concrete. Absorb hulk liquid with fly ash or cement powder. Add caustic soda.

Air Spill: Apply water spray to knock down and reduce vapors. Knock-down water is corrosive and toxic and should be diked for containment and later disposal.

Water Spill: Neutralize with caustic soda.

If Dissolved, at a concentration of $10 \mathrm{ppm}$ or greater, apply activated carbon at ten times the amount that has been spilled.

Use mechanical dredges or lifts to extract immobilized masses of pollution and precipitates.

\section{SECTION 7: HANDLING AND STORAGE}

Storage: Observe all federal, state and local regulations when storing or disposing of this substance. For assistance, contact the district director of the environmental protection agency.

Protect against physical damage. Separate from combustible, organic or easily oxidizable materials and especially isolate from acetylene, ammonia, hydrogen, hydrocarbons, ether, turpentine, and finely divided metals. Store outdoors or in a well-ventilated, detached or segregated areas of noncombustible construction (NFPA 49, Hazardous Chemicals Data, 1975).

Store away from incompatible substances.

Consult NFPA Publication 43C, Storage of Gaseous Oxidizing Materials, for storage requirements.

Threshold Planning Quantity (TPQ): The Superfund Amendments and Reauthorization Act (SARA) Section 302 requires that each facility where any extremely hazardous substance is present in a quantity equal to or greater than the TPQ established for that substance notify the state emergency response commission for the state in which it is located. Section 303 of SARA requires these facilities to participate in local emergency response planning (40 CFR 355.30). 


\begin{tabular}{|c|c|}
\hline \multicolumn{2}{|l|}{ Chbrine: } \\
\hline \multicolumn{2}{|c|}{$\begin{array}{l}5 \text { ppm - Any chemical cartridge respirator with cartridge(s) providing protection against chlorine. Any } \\
\text { supplied-air respirator. Any self-contained breathing apparatus. }\end{array}$} \\
\hline \multicolumn{2}{|c|}{$\begin{array}{l}12.5 \mathrm{ppm} \text { - Any supplied-air respirator operaled in a continuous-flow mode. Any powered, air-purifying } \\
\text { respirator with cartridge(s) providing protection against chlorine. }\end{array}$} \\
\hline \multicolumn{2}{|c|}{$\begin{array}{l}25 \mathrm{ppm} \text { - Any self-eontained breathing apparatus with a full facepiece. Any supplied-air respirator with a full } \\
\text { facepiece. Any air-purifying, full-facepicec respirator (gas mask) with a chin-style, front- or back-mounted } \\
\text { canister providing protection any poweted, air-purifying respirator with a tight-fitting facepicce. Any } \\
\text { cartridge(s) providing protection against chlorine. Any chemical cartridge respirator with a full facepiece and } \\
\text { cartridge(s) providing protection against chlorine. }\end{array}$} \\
\hline \multicolumn{2}{|c|}{$\begin{array}{l}30 \mathrm{ppm} \text { - Any supplied-air respirator that has a full facepiece and is operated in a pressure-demand or other } \\
\text { positive-pressure mode. }\end{array}$} \\
\hline \multicolumn{2}{|c|}{$\begin{array}{l}\text { Escape - any air-purifying, full-facepice respirator (gas mask) with a chin-style, front- or back-mounted } \\
\text { canister providing protection against chlorine. Any appropriate escape-lype, self-contained breathing apparatus. }\end{array}$} \\
\hline \multicolumn{2}{|c|}{ For Firefighting and Other Immediately Dangerous to Life or llealth Conditions: } \\
\hline \multicolumn{2}{|c|}{$\begin{array}{l}\text { Any self-eontained breathing apparatus that has a full facepiece and is operated in a pressure-demand or other } \\
\text { positive-pressure mode. }\end{array}$} \\
\hline \multicolumn{2}{|c|}{$\begin{array}{l}\text { Any supplied-air respirator that has a full facepiece and is operated in an pressure-demand or other positive- } \\
\text { pressure mode in combination with an auxiliary self-eontained breathing apparatus operated in pressure-demand } \\
\text { or other positive-pressure mode. }\end{array}$} \\
\hline \multicolumn{2}{|c|}{ SECTION 9: PHYSICAL AND CHEMICAL PROPERTIES } \\
\hline $\begin{array}{l}\text { Description: Pale greenish-yellow gas with a characteristic, } \\
\text { suffocating odor. }\end{array}$ & Molecular Weight: 70.906 \\
\hline Molecular Formula: $\mathrm{Cl}_{2}$ & Boilling Point: $-31^{\circ} \mathrm{F}\left(-35^{\circ} \mathrm{C}\right)$ \\
\hline Melting Point: $-150^{\circ} \mathrm{F}\left(-101^{\circ} \mathrm{C}\right)$ & $\begin{array}{l}\text { Vupor Pressure (mm IIg): } \\
\quad 5168 \mathrm{~mm} \mathrm{Hg} @ 21^{\circ} \mathrm{C}\end{array}$ \\
\hline Vapor Density (Air $=1): 2.49$ & $\begin{array}{l}\text { Specific Gravity (water }=1) \text { : } \\
\quad 3.214 \text { grams } / \text { liter } @ 0^{\circ} \mathrm{C}\end{array}$ \\
\hline Water Solubility: $1.46 \% @ 0^{\circ} \mathrm{C}$ & Odor 'Threshold: $0.01 \mathrm{ppin}$ \\
\hline Solvent Solubility: Soluble in alkalies. & \\
\hline
\end{tabular}




\section{SECTION 10: STABILITY AND REACTIVITY}

Reactivity: Stable under normal temperatures and pressures.

Conditions to Avold: Avoid contact with combustible materials (wood, paper, oil, etc); contact may result in ignition or explosion. Material may be poisonous; avoid inhalation of vapors or contact with skin. Do not allow material to contaminate water sources.

Chlorine Incompatibilities:

Actylene: Explosive reaction

Akchols: Pormation of explosive alkyl hypochlorites.

Alkyl Isothiourea Salts: Formation of explosive nitrogen trichloride.

Ammonia: Explodes when healed.

Antimony: Jgnition reaction

Arsenic: Spontaneous ignition.

N-Arylsulfinamides: Possible violent reaction.

Benzene: Explosive reaction catalyzed by light

Boron: Ignites on contact.

Bromine Pentafluoride: Explosive reaction.

Cukium Chlorite: Forms explosive chlorine dioxide.

Cakium Nitride: Incandescent reaction.

Carbon (activated): Ignites on contact.

Carbon disulfide: Explosive reaction in the presence of iron catalyst.

Cesium Nitride: Attacked by chlorine.

3-Chkoropropyne: Possible explosion.

Chromyl Chkoride + Carbon: Possible explosion.

Combustible Materials: Contact with the liquid is likely to result in an explosion. Contact with the gas may result in ignition or an explosion.

Diborane: Explodes on contact at ambient temperatures.

Dichloromethylarsine: Possible explosion.

Diethyl Ether: Explodes.

Diethylzinc: Ignition.

Dimethylformamide: Explosion hazard.

Dimethyl Phosphoramidate: May form explosive nitrogen trichloride.

Dioxygen Difluoride: Ignition or explosive reaction.

Disilyl Oxide: Explosive reaction.

4,4' - Dithlodimorpholine: May form explosive compound. 


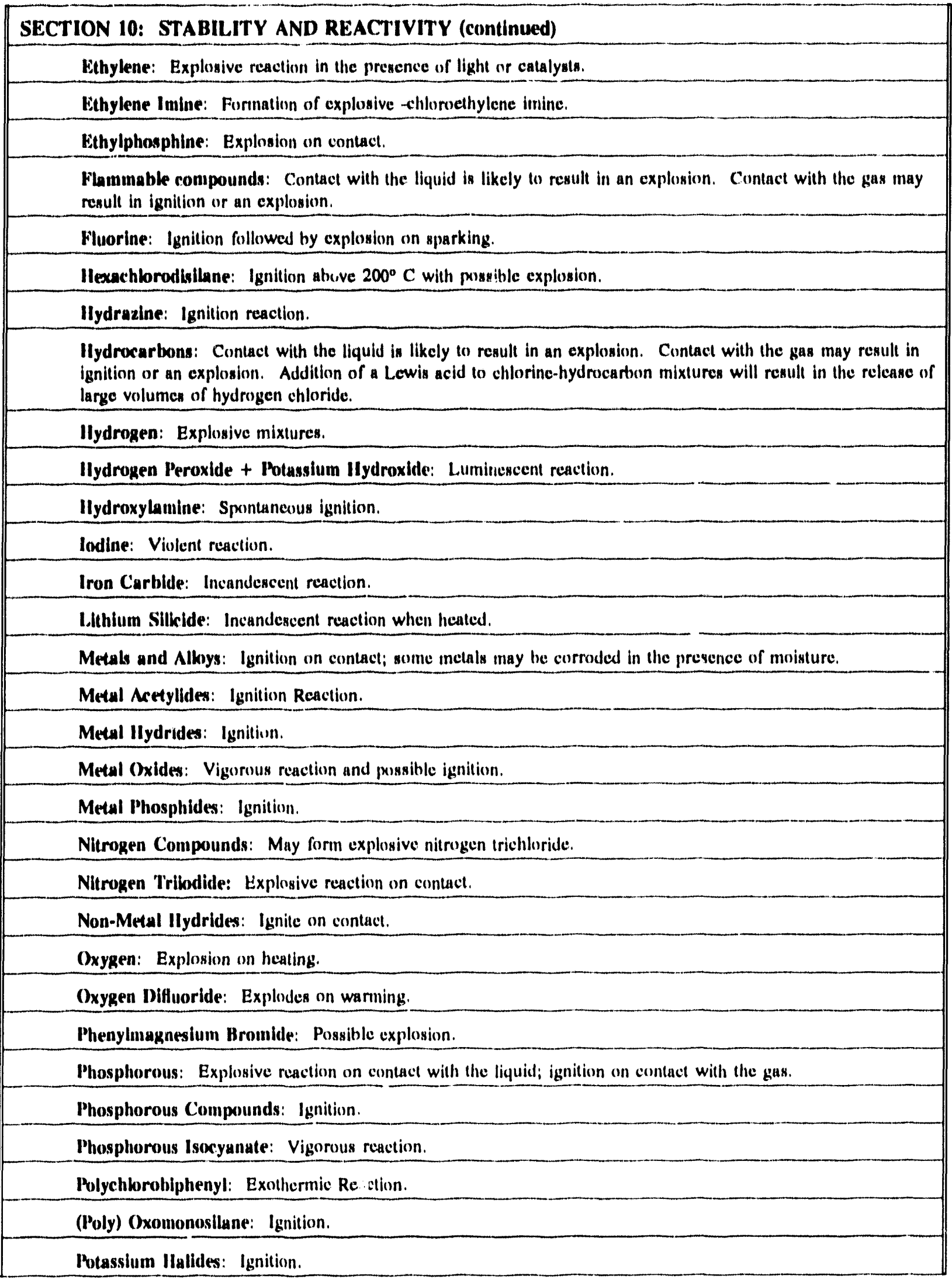




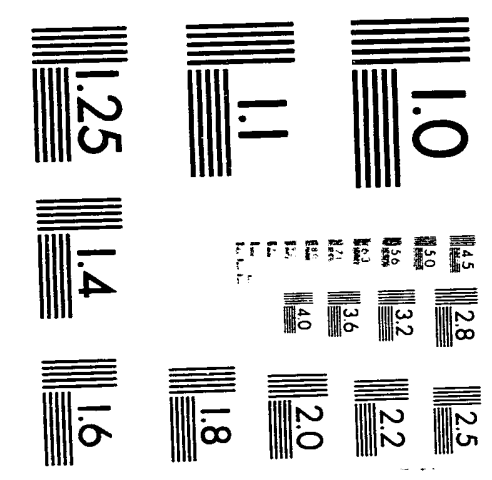



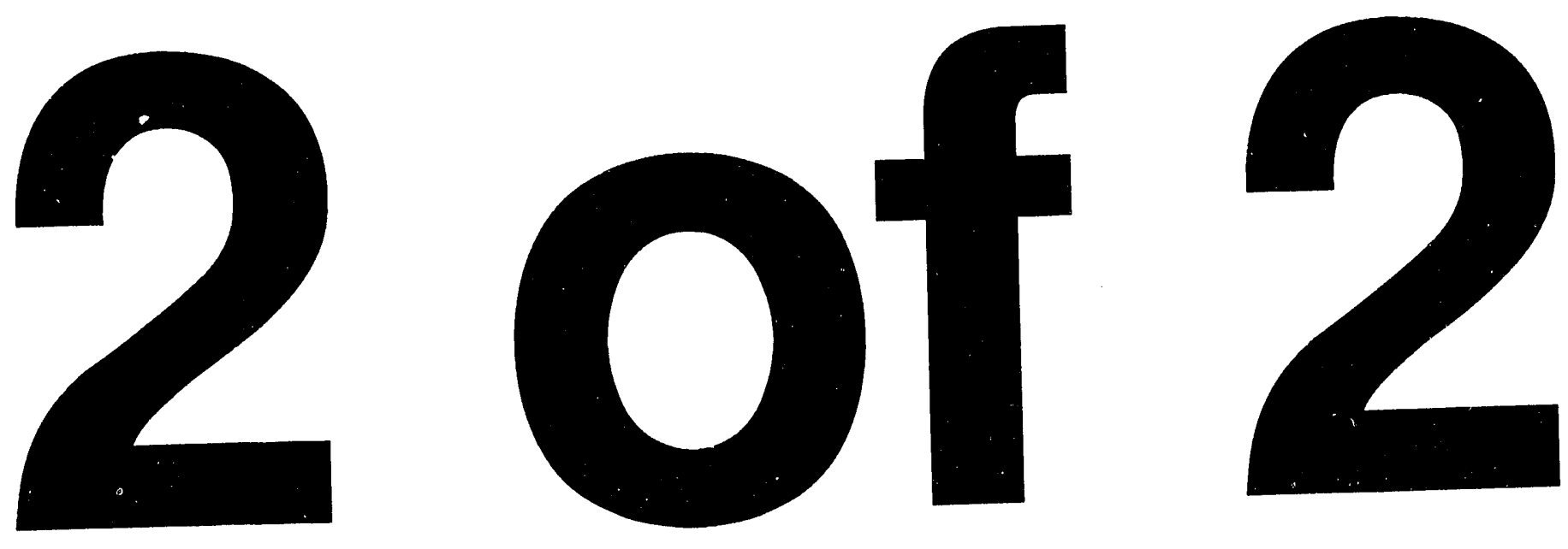


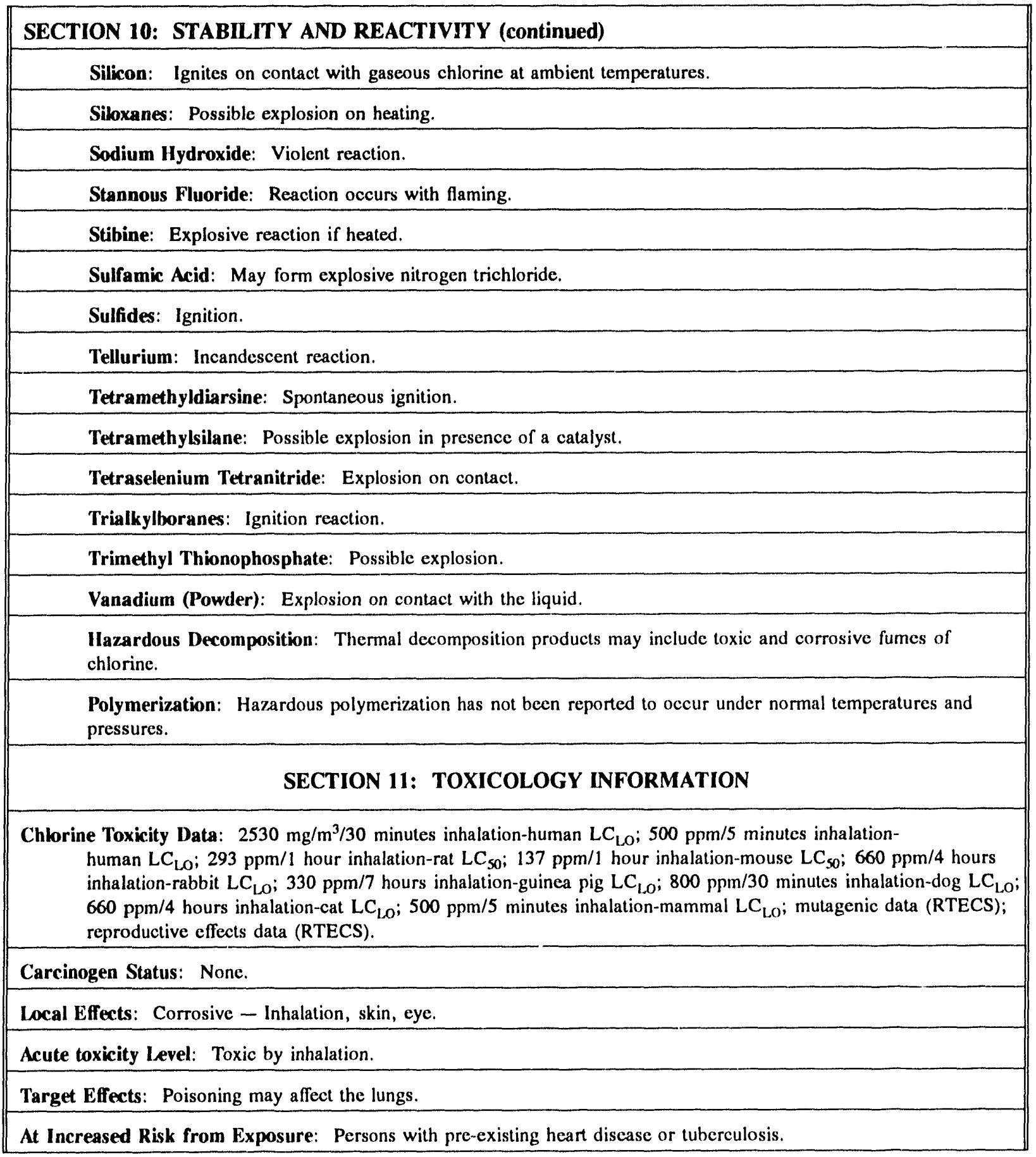




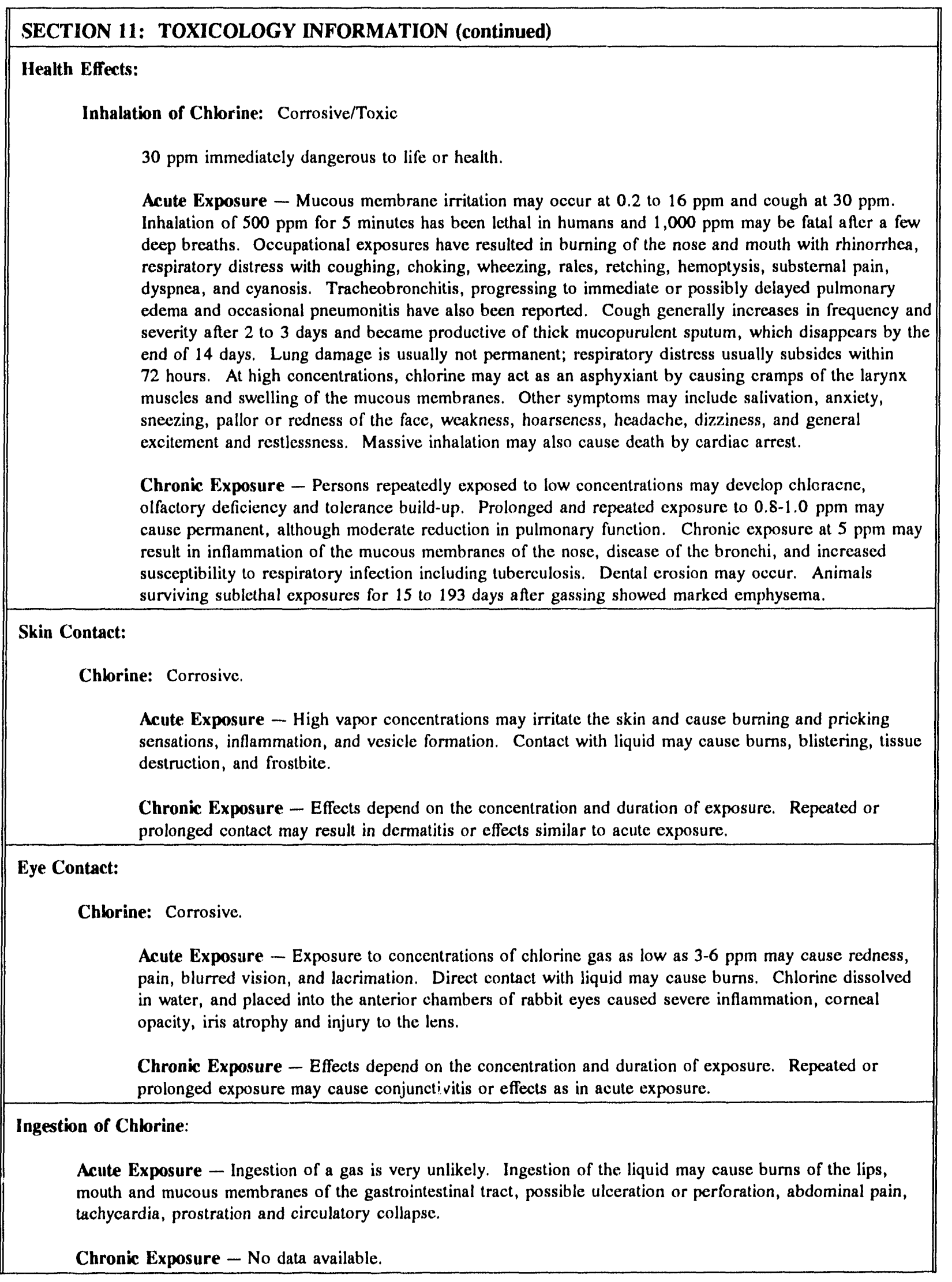




\section{SECTION 12: ECOLOGICAL INFORMATION}

Environmental Impact Rating (0-3): No data available.

Acute Aquatic Toxicity: No data available.

Degradability: No data available.

Log Bioconcentration Factor (BCF): No data available.

Log Octanol/Water Partition Coefficient: No data available.

\section{SECTION 13: DISPOSAL INFORMATION}

RCRA Hazardous Waste: No data available.

Waste Disposal: Disposal must be in accordance with standards applicable to generators of hazardous waste, 40 CFR 262, EPA Hazardous Waste number D001. A 100-pound (CERCLA Section 103) Reportable Quantity.

\section{SECTION 14: TRANSPORTATION INFORMATION}

Department of Transportation Hazard Classification:

49 CFR 172.101, Nonflammable gas

Department of Transportation Labeling Requirements:

49 CFR 172.101 and Subpart E, Nonflammable gas and poison

Department of Transportation Packaging Requirements:

49 CFR $173.304 ; 49$ CFR 173.314 and 49 CFR 173.315

Exceptions: None

Final rule on hazardous materials regulations (HMR, 49 CFR Parts 171-180), Docket numbers HM-181, HM-181A, HM-181B, HM-181C, HM-181D and HM-204. Effective date October 1, 1991. However, compliance with the regulations is authorized on and after January 1,1991 . (55 FR 52402, 12/21/90).

Except for explosives, inhalation hazards, and infectious substances, the effective date for hazard communication requirements is extended to October 1, 1993. (56 FR 47158, 09/18/91).

U.S. Department of Transportation Shipping Name-ID Number: 49 CFR 172.101, Chlorine-UN 1017

U.S. Department of Transportation Hazard Class or Division: 49 CFR 172.101, 2.3 - Poisonous Gas

U.S. Department of Transportation Labeling Requirements: 49 CFR 172.101 and Subpart E, Poison Gas

U.S. Department of Transportation Packaging Authorizations:

Exceptions: None

Non-Bulk Packaging: 49 CFR 173.304

Bulk Packaging: 49 CFR 173.314 and 49 CFR 173.315 


\section{SECTION 14: TRANSPORTATION INFORMATION (continued)}

U.S. Department of Transportation Packaging Authorizations: 49 CFR 172.101

Passenger Aircraft or Railcar: Forbidden

Cargo Aircraft Only: Forbidden

\section{SECTION 15: REGULATORY INFORMATION}

TSCA Status: $\mathbf{Y}$

Other Regulatory Information Available:

CERCLA Section 103 (40 CFR 302.4): Yes 10 pounds RQ

SARA Section 302 (40 CFR 355.30): $\quad$ Yes 100 pounds TPQ

SARA Section 304 (40 CFR 355.40): $\quad$ Yes 10 pounds RQ

SARA Section 313 (40 CFR 372.65): $\quad$ Yes

OSIA Process Safety (29 CFR 1910.119): Yes 1,500 pounds TQ

California Proposition 65: No

SARA Hazard Categories, SARA Sections $311 / 312$ (40 CFR 370.21)

Acute Hazard: Yes

Chronic Hazard: No

Fire Hazard: $\quad$ No

Reactivity Hazard: No

Sudden Release Hazard: Yes

SECTION 16: OTHER

Copyright 1993 Occupational Health Services, Inc. All Rights Reserved.

\begin{tabular}{l|l} 
Creation Date: $10 / 16 / 84$ & Revision Date: $12 / 30 / 93$ \\
\hline
\end{tabular}

Licensed to: HEHF

D-13 
APPENDIX E:

RÉSUMÉS OF HAZOP STUDY TEAM 


\section{Area of Responsibility}

Industrial Hygiene, Chemical Safety

\section{Experience}

15 years

- Performed surveys on a nationwide basis in manufacturing, petrochemical facilities, and offices to improve indoor air quality. Evaluated exposures to asbestos and fibrous glass fibers, wood dust, respirable silica, welding fumes, metals, and other airborne particulates. Monitored personal exposures to solvent vapors, sewer gases, plastic monomers and resins, carbon monoxide, and other gases and vapors.

- Conducted heat stress monitoring and surveying for ionizing and non-ionizing radiation hazards.

- Developed asbestos training programs for more than 1,000 workers. Directed bio-environmental engineering program for Air National Guard Base.

- Reviewed facilities engineering plans pertaining to industrial hygiene. Recommended corrections and/or designed ventilation systems at manufacturing facilities.

\section{Education}

B.S., Environmental Science, University of Michigan

Other

Certified Industrial Hygienist

Certified Hazardous Waste Worker 


\section{Area of Responsibility}

Hazard Analysis Process Operator, Process Safety and Risk Management

\section{Experience}

16 years

- Plant supervisor responsible for the operation of steam, water, process air, and sanitary sewer utilities of the Hanford 300-Area. Responsibilities include maintenance and operation of chlorination process equipment and the chlorine cylinder storage area. Assisted in development of the chlorine cylinder storage and handling facilities, chlorination process equipment, and operating procedures.

- Plant operator of steam, water, process air, and sanitary sewer utilities in the Hanford 300-Area. As plant operator, controlled chlorination system, including processing and chlorination of potable water, and sampling and testing of water in accordance with State of Washington code.

\section{Education}

U.S. Navy Basic Propulsion and Engineering School

U.S. Navy Boiler Technician "A" Schoo!

\section{Other}

State of Washington Group II Water Treatment Operator 


\section{Area of Responsibility}

Hazard and Risk Analysis

\section{Experience}

22 years

- Experience in occupational safety, industrial hygiene, human factors, fire safety, and safety management.

- Consulted with numerous organizations on safety issues and processes. Assisted in program review and development and accident analysis. Performed safety process reviews and audits to determine general and chemical process hazards.

- Managed consultants and developed service programs to reduce accident frequency for the firms serviced. Managed training, industrial hygiene, and general safety programs for these consulting programs. Other responsibilities included training, safety literature development, and performance management.

- Developed preliminary hazard analyses for new and existing U.S. Department of Energy research facilities.

\section{Education}

B.S., Physics, Oregon State University

M.S., Industrial Engineering, Oregon State University

Other

Certified Safety Professional 
Area of Responsibility

Process Safety Management

\section{Experience}

10 years

- U.S. Department of Energy, Occupational Safety and Health Manager. Responsible for development of technical guidance documents in occupational safety.

- DOE Program Manager. Responsible for development of tools for DOE-wide implementation of the Occupational Safety and Health Administration rule, 29 CFR 1910.119, "Process Safety Management of Highly Hazardous Chemicals."

- OSHA, General Industry Compliance Assistance. As a safety engineer, responsible for development of the Special Emphasis Program, PETROSEP, which directed compliance personnel in conducting inspections at petrochemical facilities. Provided interpretation of OSHA standards and developed directives interpreting performance-based OSHA standards. Conducted chemical plant inspections assessing chemical process safety. Conducted workplace accident investigations involving chemical releases and explosions.

- West Virginia Department of Natural Resources, Division of Hazardous Waste Management. As a chemical engineer, reviewed Part B applications for Resource Conservation and Recovery Act facilities. Participated in the development of state hazardous waste management regulations.

\section{Education}

B.S., Chemical Engineering, Osmania University, Hyberabad, India M.S., Chemical Engineering, Ohio State University 
Area of Responsibility

Process Hazard Analysis Leader, Process Safety and Risk Management

\section{Experience}

20 years

- Hazard and operability (HAZOP) study leader for numerous facilities, including manufacturers of sulfuric acid, oleum, and liquid $\mathrm{SO}_{3}$; a hydrocarbon recovery system; startup and operating procedures for three refineries; a state-of-the-art hazardous waste disposal facility, for which accident scenarios were assessed for frequency and consequences; a batch-process catalyst manufacturing plant survey and upgrade; and an advanced absorption heat transfer system.

- Led a preliminary hazard analysis for the design of a hazardous waste processing plant. PHA addressed the locations of hazards and their relative risks. Planned and led a risk audit of a chemical process plant that used large quantities of hydrogen sulfide. The audit covered process components, operation, and maintenance, and onsite transportation. Led a risk assessment of a chemical pilot plant where temperature control was critical. Used fault trees to model system failures that could cause loss of temperature control.

- Author of numerous publications on hazard evaluation and HAZOP study procedures.

- Presented numerous seminars and workshops on risk assessment. Currently leads the American Institute of Chemical Engineers Center for Chemical Process Safety continuing education course, "Use of Hazard and Operability Studies in Process Risk Management." This course has been presented to more than 1,200 engineers and 20 different companies.

\section{Education}

B.S., Electrical Engineering, University of Cincinnati

M.S., Engineering, University of Santa Clara 


\section{Area of Responsibility}

Mechanical Engineering, Risk Assessment, Human Factors

\section{Experience}

30 years

- U.S. Department of Energy, Risk Assessment Team Manager. As Safety Analysis Division Director, performed oversight of DOE safety analyses, development of safety and risk policies, and review of reactor and non-reactor probabilistic risk assessments.

- Nuclear Regulatory Commission, Region 1, Technical Assistant. Provided technical support to regional management concerning inspection activities and risk-based applications. Inspection team leader on major probabilistic risk assessment-based inspections. Program manager of Calvert Cliff's and LaSalle PRAs.

- Design and safety specialist in space electric and nuclear applications at Hittman Associates, Inc.

- U.S. Atomic Energy Commission. Program manager for space electric component development, reactor core and shielding design, and major nuclear project construction.

\section{Education}

B.S., Nuclear Engineering, New York State Maritime College M.B.A., Engineering Management, George Washington University

\section{Other}

Certification, Oak Ridge School of Reactor Technology 


\section{Area of Responsibility}

Chemical Engineering, Hazard and Risk Analysis

\section{Experience}

20 years

- Group Leader, Risk and Safety Analysis.

- Project manager for the Liquified Gaseous Fuels Release Prevention and Control Project.

- Project manager, task manager, and technical contributor to numerous risk and safety analyses of energy-related systems, including nuclear reactors and fuel cycle facilities, nuclear waste facilities, chemical waste facilities, and chemical facilities.

- Preparation of safety analysis reports for U.S. Department of Energy nuclear and chemical facilities at the Hanford Site.

\section{Education}

M.S., Chemical Engineering, University of Washington

B.S., Chemical Engineering, Carnegie Mellon University

\section{Other}

Registered Professional Engineer, Washington 
Area of Responsibility

Industrial Hygiene, Hazard and Risk Analysis

\section{Experience}

22 years

- Performed risk and safety analyses for chemical operations in various U.S. Department of Energy facilities at the Hanford Site. Responsible for safety documentation of the new Pacific Northwest Laboratory Environmental and Molecular Sciences Laboratory.

- Developed an occupational health and safety program for the International Atomic Energy Agency Department of Safeguards.

- Senior Industrial Hygienist for PNL with a staff of 3,000.

- Regional Safety Manager for the U.S. Fish and Wildlife Service supporting managers of fish hatcheries and wildlife refuges in a six state region.

- System safety engineer at Headquarters, U.S. Army Test and Evaluation Command, and at two proving grounds. Supported safety test design and evaluation. Responsible for the resolution of technical occupational safety and health issues at the proving grounds.

\section{Education}

M.E., Industrial Engineering (System Safety), Texas A\&M University, 1974

B.S., Industrial Engineering, University of Washington, 1971

B.S., Mechanical Engineering, University of Washington, 1971

\section{Other}

Certified Safety Professional

Certified Industrial Hygienist

Professional Engineer in Safety Engineering in the State of California 


\section{Area of Responsibility}

Hazard Analysis, Process Engineer

\section{Experience}

23 years

- Plant Engineer in the 300-Area Utilities and Effluent Treatment Plant, leading efforts in domestic and process sewer upgrades, installation of filter backwash pond and outfall, construction of filter plant chlorine storage facility, installation of new chlorinators and of treated effluent disposal system, replacement of ash sluice pond, and installation of metering manhole for the process sewer.

- Waste Water Plant Superintendent for Industrial and Domestic Treatment Plant of the City of Prosser, Washington, including maintenance and operation of spray field and sewer system. Designed reviews of new filtration plant and waste water plant upgrade.

- Chief operator for the water treatment plant for the City of Yakima, Washington, including supervision of influent, grit, and rag removal; primary clarification centrifuge; primary and secondary digesters; trickling filters; activated sludge final clarification; chlorination; and spray field for industrial wastes.

- Operator and maintenance employee for the watershed of the City of The Dalles, Oregon, Waste Water Treatment Plant and Filter Plant. Participated in waste water plant construction, startup, and operation.

\section{Education}

Domestic and industrial waste water treatment training, Linn Benton Community College Work-related classes at Columbia Basin College

\section{Other}

State of Washington Group IV Waste Water Treatment Process Operator State of Washington Group II Waste Water Treatment Process Operator 

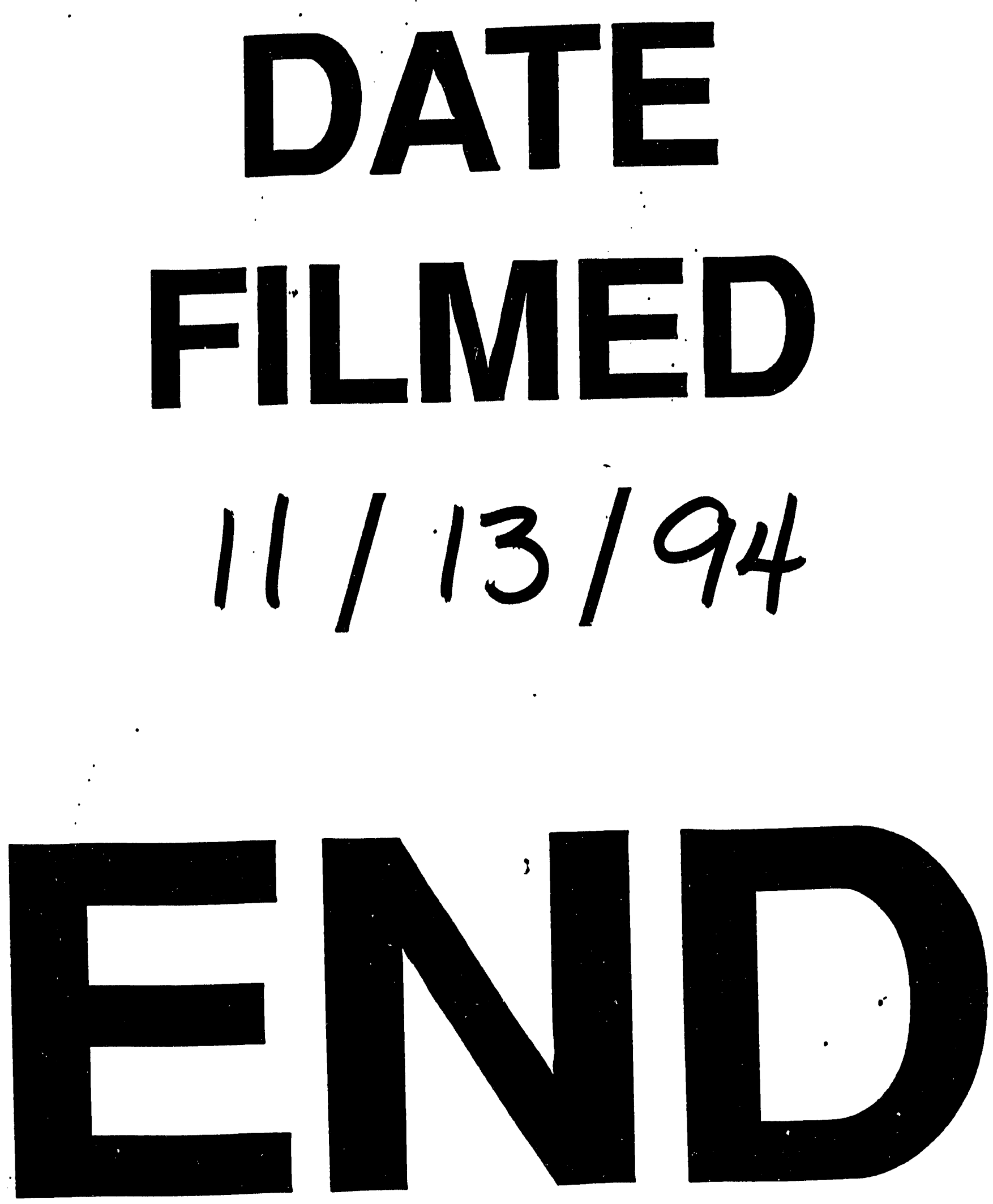
